DEPARTMENT OF THE INTERIOR UNITED STATES GEOLOGICAL SURVEY CHARLES D. WALCOTT, DIRECTOR

\title{
THE YAMPA COAL FIELD, ROUTT COUNTY, COLORADO
}

BY

N. M. FENNEMAN AND HOYT S. GALE

WITH A CHAPTER ON THE CHARACTER AND USE OF THE YAMPA COALS BY

MARIUS R. CAMPBELL

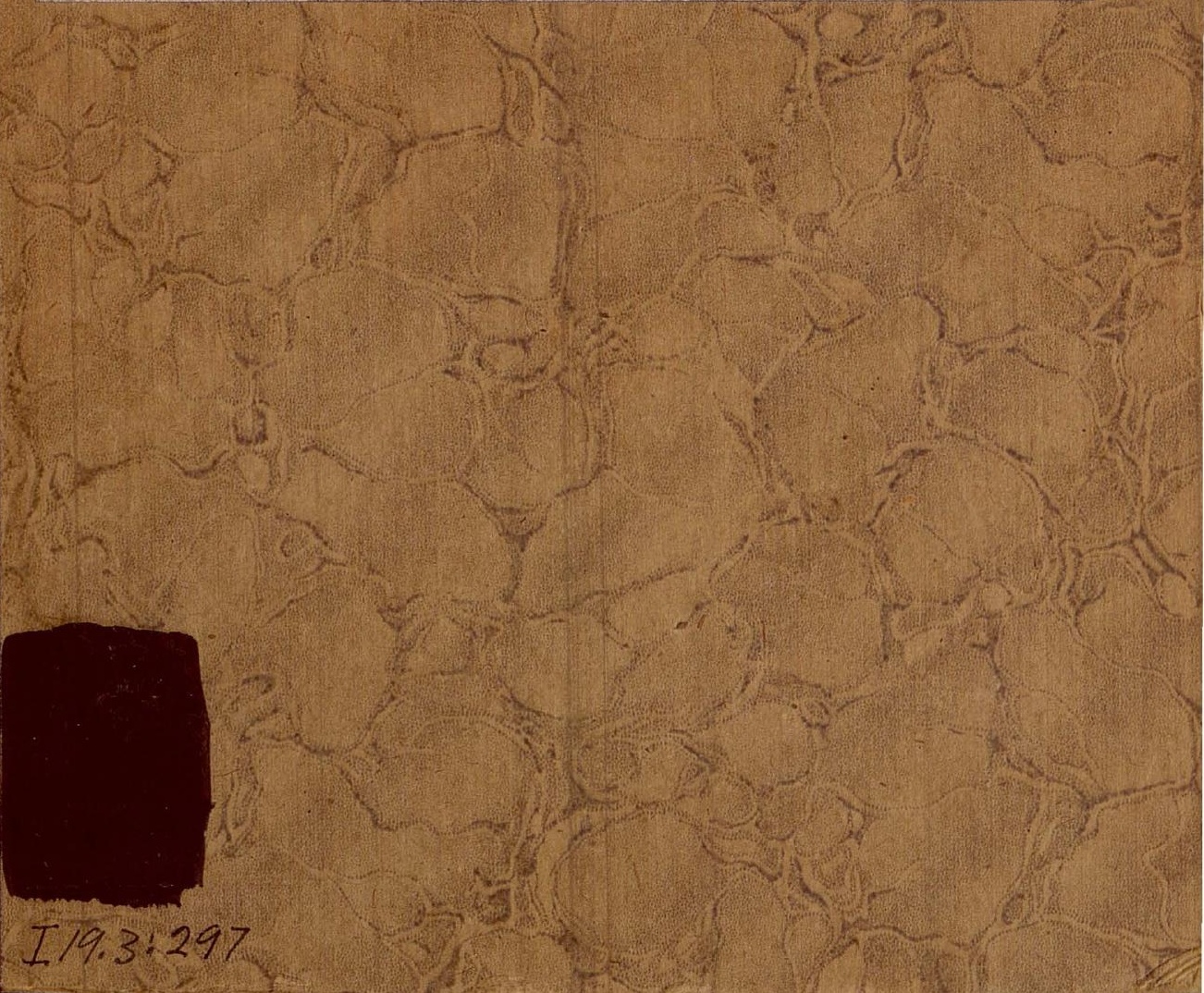





\title{
THE YAMPA COAL FIELD, ROUTT COUNTY, COLORADO
}

BY

\author{
N. M. FENNEMAN AND HOYT S. GALE
}

WITH A CHAPTER ON THE CHARACTER AND USE OF THE YAMPA COALS

MARIUS R. CAMPBELL

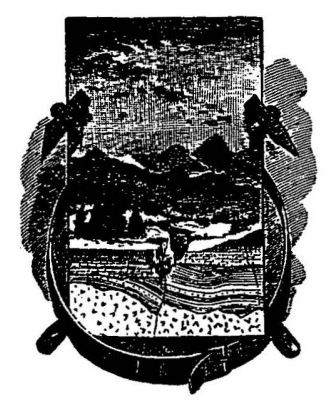

W ASHINGTON

GOVERNMENT PRINTING OFFICE 



\section{CONTENTS.}

The Yampa Coal Field, by N. M. Fenneman and Hoyt S. Gale. Page.

Introduction . . . . . . . . . . . .

Location . . . . . . . 7

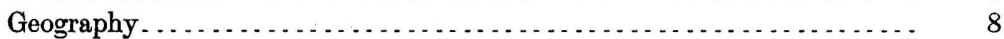

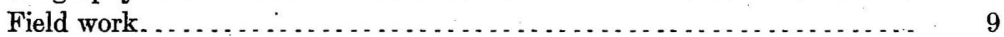

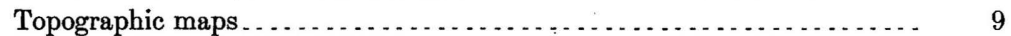

Literature . . . . . . . . . . . 11

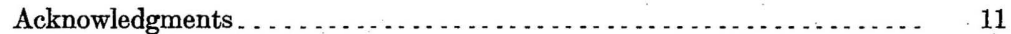

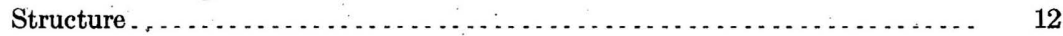

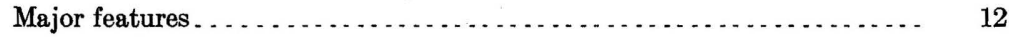

Minor folds . . . . . . . . . . . . . . . .

Distribution . . . . . . . . 13

Tow Creek anticline. . . . . . . . . . . . . . .

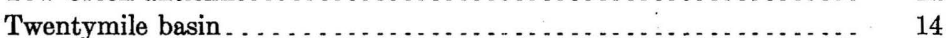

Sage Creek anticline . . . . . . . . . . . . . . . . . . . . . . . . . . 15

Folds west of Hayden . . . . . . .

Faults . . . . . . .

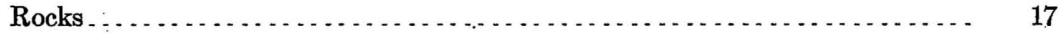

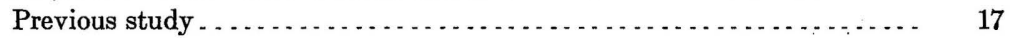

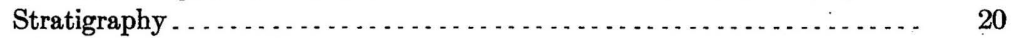

Description of formations ................................. 20

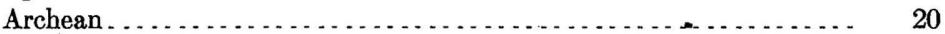

Pre-Cretaceous . . . . . . . . . . . . . . . 21

Cretaceous . . . . . . . . .

Dakota formation. . . . . . . . . . . . . .

Mancos shale ......................................... 22

Mesaverde formation ............................... 22

General description. . . . . . . . . .

Lower coal group . . . . . . . . . . . . . . . . . . . . . . . . . . . . $\quad 24$

Trout Creek sandstone member..................... $\quad 26$

Middle coal group . . . . . . . . . . . . . . . . . . . . . . . 26

Twentymile sandstone member . . . . . . . . . . . . . . . . . . $\quad 27$

Upper coal group .............................. 27

Lewis shale . . . . . . . . . . . . . . . . . . . . . . . . . . . 28

Laramie formation. . . . . . . . . . . . . . . . . . . . . . . . . 29

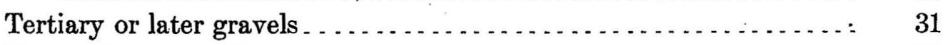

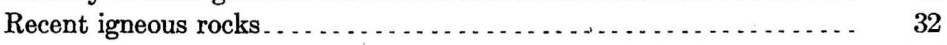

Coal . . . . . . . . . . 33

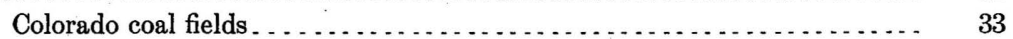

Area . . . . . . .

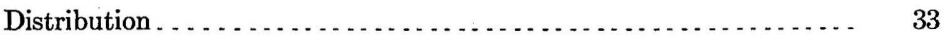

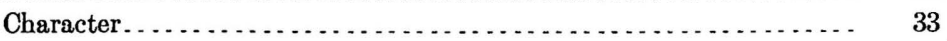

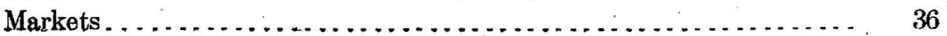


The Yampa Coal Field, by N. M. Fenneman and Hoyt S. Gale-Continued: Page. Coal-Continued.

Yampa field . . . . . . . .

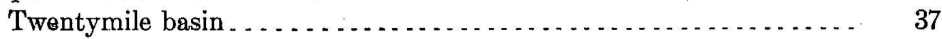

Structure and subdivisions . . . . . . . . . . . . . . . . . . . . . 37

Twentymile Park district . . . . . . . . . . . . . . . . . . . . . . . . . . . $\quad 38$

Dunkley Canyon district. ........................... $\quad 40$

Oak Creek district. . . . . . . . . . . . . 41

Occurrence . . . . . . . . . . . .

James mine ..................................... 41

Shuster mine..................................... 42

Steamboat Springs Electric Company mine . . . . . . . . . . . . 43

Miscellaneous prospects....................... 44

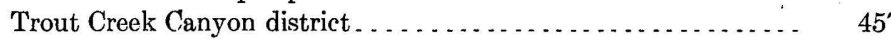

Eddy district . . . . . . . . .

General description . . . . . . . . . .

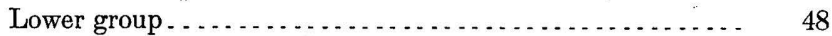

Middle group . . . . . . . . 50

Upper group . . . . . . . . . . . . . 50

Pool district . . . . . . . . . . . . . 51

General description . . . . . . . . . . . . . 51

Middle group . . . . . . . . . . . . . 51

Lower group . . . . . . . . . . . . .

Prospects north of Pool . . . . . . . . . .

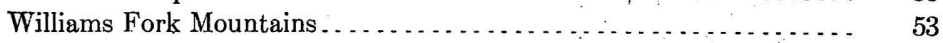

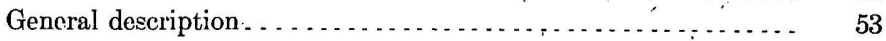

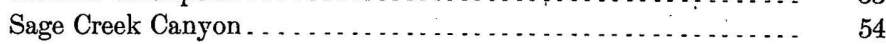

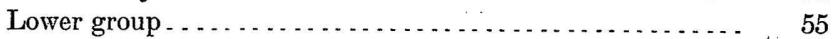

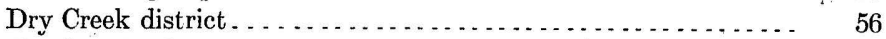

Hayden Gulch . . . . . . . . . . . . . . . . . . . . . . . . . . 57

Other gulches north of Williams Fork . . . . . . . . . . . . . . 57

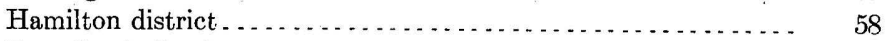

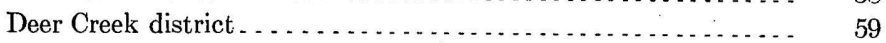

Yampa Valley below Craig . . . . . . .

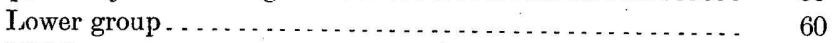

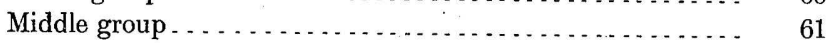

Upper group. . . . . . . . . . .

Middle coals at Big Bottom . . . . . . . . . . . . . . . . . . . 62

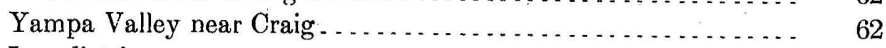

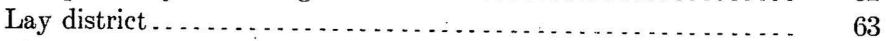

Wolf Creek district and Anthracite Range . . . . . . . . . . . . . . . . 63

General description................................ 63

Yampa Canyou and Wolf Creek district. . . . . . . . . . . . . . . 64

Upper group . . . . . . . . . . . . . .

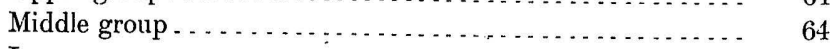

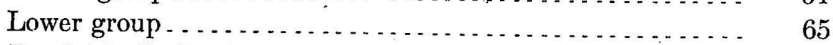

Butcherknife Creek . . . . . . . . .

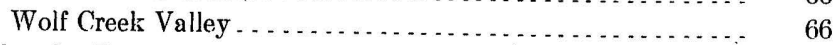

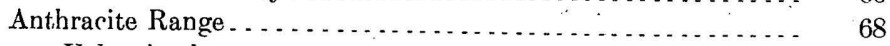

Volcanic phenomena. . . .

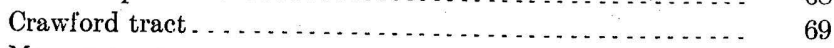

Morgan tract. . . . .

School-section mine.............................

Miller and tributary gulches...................... 71 
The Yampa Coal Field, by N. M. Fenneman and Hoyt S. Gale-Continued. Coal-Continued.

Yampa ficld-Continued.

Wolf Creek district and Anthracite Range-Continued.

Anthracite Range-Continued.

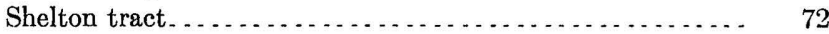

Slope of sand mountain . . . . . . . . . . . . . . . . . . . 73

Area of anthracite field . . . . . . . . . . . . . . . . . . . . . 73

Elkhead and Quaker Mountain district. . . . . . . . . . . . . . $\quad 74$

General description . . . . . . . . . . . . . . . . . . . . . . . 74

Coal beds. . . . . . . . . . . . . . . . . . . . . . . . . . . . . 74

Hayden openings:................................... 74

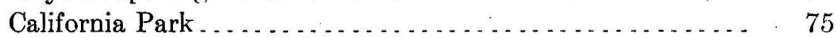

"The Potholes" on Elkhead Creek . . . . . . . . . . . . . . 76

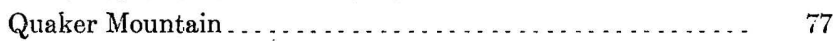

Mouth of Elkhead Creek. ........................ 78

Fortification Creek. ................................ 78

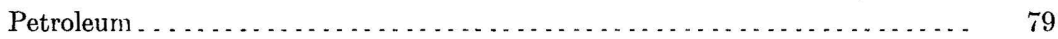

Vicinity of Pool . . . . .

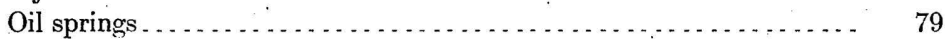

Wells . . . . . . .

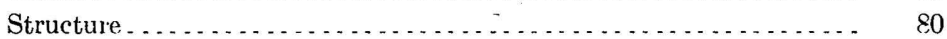

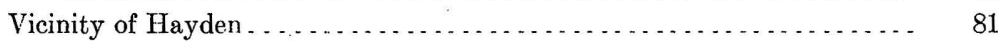

Vicinity of Lay . . . . . . . . . . . . . . . . . . . . . . . . . . . . 81

Character and Use of the Yampa Coals, by Marius R. Campbell. . . . . . . . . 82

Chemical composition . . . . . . . .

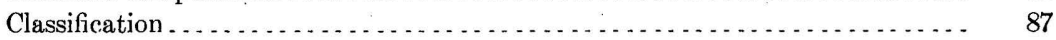

Utilization . . . . . . . . . . . . .

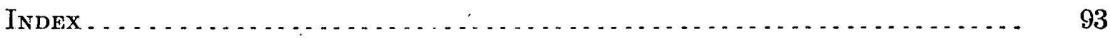

\section{L L U S T'R A T I O N S.}

Page.

Plate I. Map of Yampa coal field, Colorado . . . . . . . . . . . . . . . . . . Pocket.

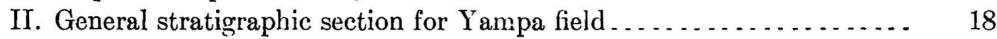

III. Geologic map of Yampa field and vicinity . . . . . . . . . . . . . . . 20

IV. A, Yampa Valley and volcanic stocks north of town of Yampa; $B$, Ledges of the Twentymile sandstone at northern end of Twentymile basin.

V. Williams Park and the lower "barren hogbarks" of the Mesaverde formation, taken fron Dunkley post-office ................ 24

VI. Trout Creek sandstone in Yampa Canyon . . . . . . . . . . . . . . . . . . . 26

VII. Twentymile sandstone at Wadge ranch, Yampa Canyon . . . . . . . . . 28

VIII. Structure and topography of Mesaverde formation at Dunkley Canyon -

IX. $A$, Anthracite coal seam and the overlying igneous sheet aî "The Potholes" on Elkhead Creek; $B$, Columnar coal seamı on upper Wolf

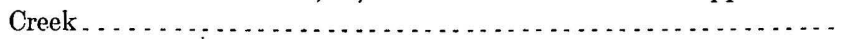

Fic. 1. Map showing structure in the Yampa field . . . . . . . . . . . . . .

2. Index map of Colorado coal fields . . .

2. Index map of Cholorado coal fields. 



\section{ERRATA.}

[Bulletin No. 297 of the United States Geological Survey.]

Page 62. Line 20 from bottom should read: "upper coal group. One of these is represented on the map as belonging to".

Plates I and III. Some changes of geologic boundary lines were made on Plate I just before printing it, which it was not found practicable to incorporate also in the smaller map, Plate III.

Plate V, opposite page 24, is the Trout Creek sandstone in Yampa Canyon; it should have been placed opposite page 26 and been numbered VI.

Plate VI, opposite page 26, is the Twentymile sandstone at Wadge ranch, Yampa Canyon; it should have been placed opposite page 28 and been numbered VII.

Plate VII, opposite page 28, is Williams Park and the lower barren hogbacks of the Mesaverde formation; it should have been placed opposite pæge 24 and been numbered $\mathrm{V}$. 



\title{
THE YAMPA COAL FIELD, ROUTT COUNTY, COLO,
}

\author{
By N. M. Fennemain and Hoyt S. Gale.
}

\section{INTRODUCTION.}

\section{LOCATION.}

The Yampa coal field lies in the eastern part of Routt County, Colo. It takes its name from Yampa (Bear) River, which is the principal stream of this part of the country. The territory within which coal is known to occur is irregular in outline and extends considerably beyond the field as described in this report, but the more valuable coal beds are limited to an area of about 1,200 square miles in the center of the valley, west of the Park Range and north of the White River Plateau and Axial basin. The field is roughly triangular in outline, its corners being, approximately, at Lay post-office, Sand Mountain, and a few miles north of Yampa village. The village of Hayden is located near the center of the field, and Steamboat Springs, the chief town of the county, is about 28 miles east of Hayden and about 10 miles east of the border of the coal field.

At present the field is far removed from railroad communication, being about midway between the Denver and Rio Grande on the south and the Union Pacific on the north. The Denver, Northwestern and Pacific (Moffat) road is now running trains between Denver and Sulphur Springs in Middle Park, and it is the announced intention to extend this road through Gore Canyon and down Yampa River to Salt Lake City. If this is done, the field will have railroad connection with both the east and west. At present the field may be reached by stage from Wolcott and Rifle, on the Denver and Rio Grande Railroad; from Sulphur Springs, on the Moffat road; and from Rawlins, Wyo., on the Union Pacific road. Steamboat Springs is 75 miles from Wolcott and about the same distance from Sulphur Springs, both routes passing through Yampa village. Craig is about 100 miles from Rifle and 112 miles from Rawlins. 


\section{GEOGRAPHY.}

The district is a part of the great upland known as the Colorado Plateau, which extends westward from the foothills of the Rocky Mountains. Although called a plateau, the general level of the upland surface is frequently interrupted by higher summits or ranges of mountains and by deep valleys and canyons carved by the streams. Much of the region may be described as open and comparatively level, while much is hilly, rising to parts that are ruggedly mountainous. The open plains along Yampa River range in elevation from 6,000 feet on the lower course of the river to about 7,500 feet in the upper valleys. Peaks of the Elkhead Mountains, which bound the field on the north, and of the White River Plateau, which bound it on the south, rise to heights of 11,000 feet. On the east the highest summits of the Park Range rise to about 12,000 feet.

The Park Range of the Rocky Mountains is here the Continental Divide, separating the waters of the Mississippi River system on the east from those of the Pacific Ocean drainage on the west. This watershed is sinuous, being broken up and offset by the various parks which lie in the heart of the mountain area. The Continental Divide is on the Front Range, in the vicinity of Denver. Thence it follows westward along the high divide, separating North and Middle parks, whence it is continued northward along the summits of the Park Range, passing into Wyoming as a smoothly rounded ridge of comparatively slight relief and gentle slopes.

Little Snake, Yampa, and White rivers drain westward through northwestern Colorado, emptying into Green River near the ColoradoUtah State line. Green River, in turn, is the principal tributary of "Colorado River of the West," or, as has been pointed out by Dr. C. A. White, "it is, more properly speaking, the northern portion of that river and ought never to have received another name." The uppermost headwaters of Yampa River consist of many mountain streams that head on the western flanks of the Park Range, the northern slopes of the White River Plateau, and the ridges and slopes of the Elkhead Mountains. As these rugged slopes are in large part forest covered, the streams contain an abundant supply of fresh, clear water. In their lower courses they enter the broad stretches of semiarid valley and prairie lands, and the smaller streams sink or dry up during the greater part of the summer. The alkaline salts that leach from the prairie soils render the waters of the smaller streams unfit for use of man, and the cattle that now range throughout the grass lands of the prairie hills pollute all but the larger flowing streams.

Yampa River flows almost its entire coürse through alternate stretches of open valleys and canyons. In its lower course, below the limits of the field here described, it flows through a succession of deep, 
sharp canyons. Below Lily Park for 25 or 30 miles of its course it occupies an almost inaccessible canyon some 1,500 feet in depth, which beyond its junction with Green River has been cut to almost twice this depth.

\section{FIELD WORK.}

The field work which forms the basis of this report oscupied from June 20 to October 20, 1905. The systematic geologic work is mainly the work of the two authors. Mr. M. R. Campbell, in general charge of coal investigations for the United States Geological Survey, spent two weeks with the party in the field. Dr. T. W. Stanton spent a like period with the party in collecting fossils and determining significant fossil horizons. The mapping of the more important roads and the topography adjacent to them is mainly the work of R. C. Allen. The office work in the preparation of the topographic map was the work of Hoyt S. Gale, assisted by William O. Tufts, topographer.

\section{TOPOGRAPHIC MAPS.}

Up to the present time the Yampa Valley has been so nearly inaccessible that there has been little or no use for accurate maps; but now with the prospect of railroad communication and the development of its coal resources maps showing the character of the country are in demand. The only maps of northwestern Colorado hitherto published are the results of three general surveys. The earliest were those of the United States Geological Exploration of the Fortieth Parallel, under Clarence King, in the years 1867 to 1872 . These embraced a strip of territory 100 miles in width extending in an east-westdirection north of the Fortieth Parallel, and thus included a considerable portion of the Yampa Valley. In the summer of 1876 field parties of the United States Geological and Geographical Survey of the Territories, F. V. Hayden in charge, mapped the territory south of the King survey in the Yampa and White River valleys. The two surveys overlapped each other along a strip about 15 miles in width. The Hayden surveys covered nearly the whole State of Colorado, extending as far north as latitude $40^{\circ} 30^{\prime}$. Maps embracing the results of these surveys were published in atlas form on the scale of 4 miles to $1 \mathrm{inch}$. The King maps, while representing well the general features of the region, were not sufficiently accurate in detail nor in the expression of topographic forms to serve as a base for the geologic mapping of the present survey. The Hayden maps are in some portions similar in character to the King maps, but in general are of much higher standard and are, indeed, most excellent maps for the scale on which they were drawn. Since the year of the Hayden survey most of the readily accessible and open lands of the region have been surveyed and subdivided by the General Land Office, and township plats have been made 
of the territory thus surveyed. From these plats and from the maps of the Hayden and the King surveys numerous State and county maps have been compiled.

In view of the lack of adequate maps it was decided to devote considerable time to the preparation of a suitable base map upon which the location of the coal beds could be shown with some degree of accuracy and which also would give to investors who are not personally familiar with the region a good idea of the appearance of the country, of the possibility of town sites, and of the accessibility of the various parts of the field from a main line of railroad down Yampa River.

The base map (PI. I, pocket) is not of equal accuracy in detail throughout. All the principal roads were traversed by plane table, with common sight alidade, the distances being measured by counting the revolutions of a buggy wheel, and the altitudes determined by aneroid barometer. This work was done with care, so that circuits of from 25 to 50 miles commonly closed within a small fraction of a mile. In all traverses control was obtained by sights to the mountain peaks used as triangulation points by the Hayden and the Fortieth Parallel surveys. After careful adjustment of data thus obtained it is believed that errors in locations along lines of travel are insignificant. The topography adjacent to lines thus traversed was sketched on the plane table, the location of the more important features being fixed by intersecting sights. Starting from points on these lines traverses of a few miles, seldom exceeding 10, were made with a Brunton compass, the distances being paced either by man or horse and the lines being plotted in a notebook. Topography was sketched and locations determined from known points, as in case of the traverse made by plane table. The selection of lines thus run was determined largely by the distribution of the coal cutcrops. From the methods here described of making the map it will appear that the degree of accuracy in its different parts is roughly proportional to the economic interest which attaches to the several parts of the district.

Owing to uncertainty as to location of section corners in a large portion of the field, it was deemed impracticable, in the present survey, to make a map that would accurately represent the township and section lines. Certain section corners adjacent to the routes that were surveyed were found by inquiry among the settlers. Fences whose direction indicated that they lay upon section or section subdivision lines were noted on the surveys, and where opportunity offered inquiry was made concerning their position. The information thus gathered was scattering, and no attempt was made to make this tie between the present survey and the Land Office surveys complete. For this reason it has been thought best to omit from the map all of this data except an approximate representation of some of the town- 
ship and range lines. Relative elevations were taken with aneroid barometers, and at best they are only approximate. Barometer elevations were corrected to data kindly furnished by the Denver, Northwestern and Pacific Railway Company, consisting of a continuous line of levels from Denver down Yampa River through the length of the field, based on bench marks established in the city of Denver.

\section{LITERATURE.}

The region was visited in 1872 by Mr. S. F. Emmons, as geologist of the Fortieth Parallel Survey, and a general map and description of the geology of the area are given in the report of that survey. ${ }^{a}$

The same territory was visited in 1876 by Dr. C. A. White, geologist of the Hayden Survey, and both geologic and topographic descriptions are contained in the reports of that survey. ${ }^{b}$

Of the reports on the economic geology of the region probably the earliest important contribution is that of $\mathrm{Mr}$. R. C. Hills in the volume of Mineral Resources for 1892. ${ }^{c}$

Other references are as follows:

Chisholm, F. F., The Elkhead anthracite coal field of Routt County, Colo.: Colo. Sci. Soc. Proc., vol. 2, pt. 2, 1887, p. 147.

Storrs, L. S., The Rocky Mountain coal fields: Twenty-second Ann. Rept. U. S. Geol. Survey, pt. 3, p. 421.

Hewett, G. C., The northwestern Colorado coal region: Trans. Am. Inst. Min. Eng., vol. 17,1889 , p. 375.

— The coal fields of Routt County, Colo.: Eng. and Min. Jour., vol. 74, Nov. 1, 1902, p. 579 .

Parsons, H. F., and Liddell, Charles, The coal and mineral resources of Routt County, Colo.: Bull. Colo. School of Mines No. I, vol. 1, No. 4, January, 1903.

Weston, Wm., Yampa coal field on the line of the Moffat Road; a pamphlet issued by Denver, Northwestern and Pacific Railroad, 1905.

Ritter, E. A., Yampa coal field; a pamphlet entitled "General Information," issued by Denver, Northwestern and Pacific Railway, 1905.

\section{ACKNOWLEDGMENTS.}

The thanks of the authors are due to the owners of coal lands and to residents who have rendered assistance of various kinds. Special acknowledgments are due to $\mathrm{Mr}$. W. Weston, mining engineer and representative of the Denver, Northwestern and Pacific Railway, Dr. W. H. Nichols, of Boulder, Colo., and Mr. James H. Crawford, of Steamboat Springs, for maps and blueprints; to Mr. George Vail, of Deep Creek, Mr. Sam. G. Adams, of Steamboat Springs, and Mr. E. Shelton, of Hayden, for various maps and records and for personal assistance in the field; also to Messrs. Charles W. Harkness, Arie Keitel, H. S. Coe, and W. L. Jameson for assistance in the field.

a U. S. Geol. Exp. Fortieth Par., vol. 2, pp. 167-189 and atlas.

$b$ U.S. Geol. and Geog. Survey Terr., Tenth Ann. Rept., 1876, and atlas. See also Ninth Ann. Rept. U. S. Geol. Survey, p. 683 .

c Mineral Resources of U. S. for 1892, U. S. Geol. Survey, 1893, pp. 319-365. 


\section{STRUCTURE.}

\section{MAJOR FEATURES.}

The Yampa field as a whole is a well-defined structural unit. It is a portion of a huge basin of coal-bearing rocks included between the uplifted area of the Park Range on the east and an area of lesser uplift extending through the White River Plateau and Axial Basin on the south. This basin narrows to an apex on the southeast and

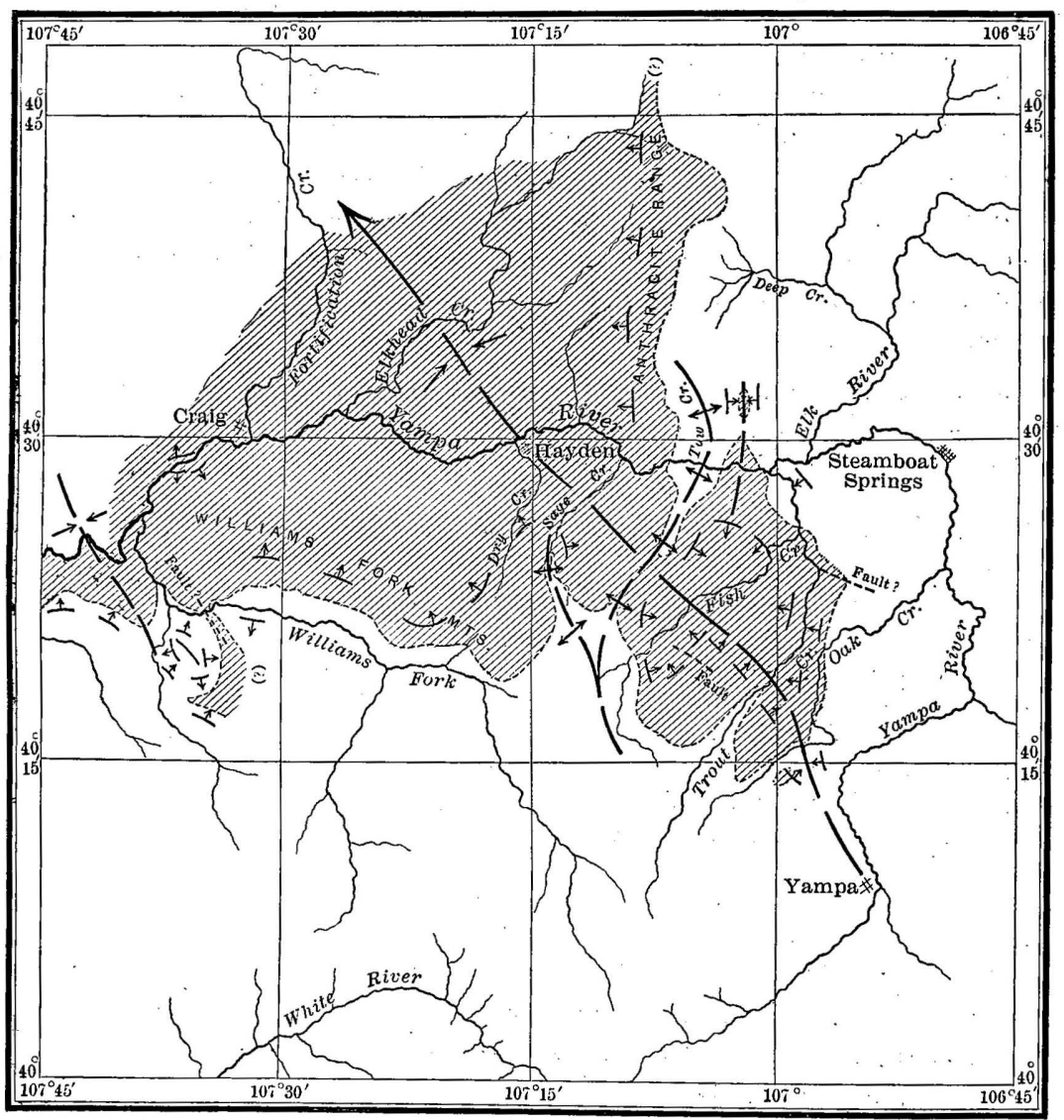

F1G. 1.-Map showing strueture in Yampa field.

broadens and deepens toward the northwest until it is lost under the cover of Tertiary rocks some miles northwest of Craig.

In fig. 1 the form of this major syncline is brought out by the shading of the area of the coal-bearing rocks, and its axis is indicated by the heavy broken line passing through the villages of Yampa and Hayden. As the rocks of the field in general dip toward the axis of the fold, and as the fold is pitching or deepening to the northwest, suc- 
cessively younger rocks show at the surface along the axial line from Yampa, where the coal-bearing rocks have been eroded, to the northwestern margin beyond Hayden, where the coal-bearing series is largely below water level, only the highest member showing at the surface. In the Williams Fork Mountains the rocks have a general dip to the north, while in the Anthracite Range the general dip is to the west, in each case toward the center of the basin. Both expose the upturned edges of the whole Mesaverde or coal-bearing formation, as is explained in greater detail in a later chapter. Rocks older than the Mesaverde occur in belts or strips of territory surrounding the upturned edges of the coal field.

Axial Basin was so called by Dr. C. A. White ${ }^{a}$ of the Hayden Survey, who used the name as a term to facilitate geologic description. As described by Doctor White it occupies a great anticlinal axis, which is the eastward prolongation of the Uinta Mountain uplift. The fold is of especial interest in the present report, since it separates the coal-bearing. strata of the Yampa field from those of the Grand River field. On both sides of this axis of uplift the sandstone ledges dip away into their respective basins, and it seems clear that recently in geologic. time these rocks probably extended continuously across from one field to the other.

\section{MINOR FOLDS.}

\section{DISTRIBUTION.}

The main basin that composes the field is complicated by a number of cross folds or wrinkles, whose axes trend approximately at right angles to that of the major fold. These are indicated in fig. 1, from which it will be seen that the most prominent of these minor folds cuts across the whole field, from Williams Park on the south to the head of "Deep Creek and Anthracite Range on the north. As the northern portion of the axis follows for some distance the valley of Tow Creek, it is referred to as the Tow Creek anticline. A branch from this same fold at its southern end extends down Sage Creek Valley and has been called the Sage Creek anticline. This latter fold plunges under the prairie lands south of Hayden and its northward continuation is lost. The Tow Creek anticline cuts off a structural basin on the southeast, whose center or deepest part lies in the open valley of Twentymile Park. It is, therefore, referred to as the Twentymile basin. West of the Tow Creek anticline and Twentymile Park are other folds and minor irregularities, some of which markedly affect the outcrop of the coal-bearing rocks and have been indicated in fig. 1. 


\section{TOW CREEK ANTICLINE.}

The fold that separates Twentymile basin from the rest of the Yampa field is a marked topographic, as well as structural feature. From its crest the soft shales of the Lewis formation have been eroded, exposing the strong sandstones of the Mesaverde formation and forming a low range of hills or mountains from 2 to 5 miles in width and rising 1,000 feet above the adjacent prairies (Pl. IV, $B$, p. 22). North of Yampa River, however, the axis of the fold has been eroded, and it is marked by the valley of Tow Creek, with high escarpment ridges of the sandstone rising sharply from the stream bed. At the mouth of Tow Creek, Yampa River cuts this fold to the base of the Mesaverde formation, and for a short distance the black shale of the underlying Mancos formation is exposed on the river bank.

The Tow Creek anticline is not symmetrical, since the strata dip at a much steeper angle on their eastern flank than on their western. The dips vary somewhat, ranging from $30^{\circ}$ to $60^{\circ}$ toward the east and rarely reaching $15^{\circ}$ toward the west. At the point where the axis of the major syncline of the field is crossed by the axis of the Tow Creek anticline, the latter sags so that the coal-bearing rocks of Twentymile basin and those of the main basin join over the crest of the cross anticlinal fold. The point is marked by a low, rounded gap, locally known as Grassy Gap, through which the wagon road passes over into Hayden Valley.

\section{TWENTYMILE BASIN.}

The structural basin southeast of Tow Creek anticline corresponds to the topographic basin whose central portion is known as Twentymile Park. This park is a prairie about 3 or 4 miles wide and some 8 miles long, of an average altitude of about 7,000 feet. In the center its surface is underlain by the Lewis shale. It has a low, rolling surface in its central part, but increases in relief around the margin as the resistant sandstone ledges of the Mesaverde rise to the surface. The inner or dip slopes are somewhat dissected and merge by degrees into the rolling prairie of the park. The hard ledges of the upper members of the Mesaverde formation stand out on the inner or dip slopes as concentric cuestas, ${ }^{a}$ among which those formed from the Trout Creek and Twentymile sandstones are usually the most prominent. As viewed from the hilltops these ridges frequently show as almost continuous escarpments for many miles, and clearly reveal to the observer the geologic structure of the field as far as they can be distinguished (Pl. IV, $B$, p. 22).

a This Spanish term, signifying a hill, ridge, or mesa, with an abrupt slope on one side and a long gentle decline on the other, is found highly convenient in describing the topography of the Colorado Plateau. 
Around the outer edges of the basin the basal sandstones of the Mesaverde formation outcrop as cuestas. The bold escarpments face outward from the basin and, in the case of the lower members of the Mesaverde sandstones, overlook on the east and south the lowlands formed upon the Mancos shale. The Tow Creek anticline has already been described as the western boundary of this basin.

Of the minor structural features of Twentymile basin the most noteworthy is an abrupt monocline which interrupts the gentle northeasterly dip on upper Trout and Middle creeks. In Trout Creek canyon the strata lie approximately horizontal from the upper end near Pinnacle post-office to near the lower end, where the beds suddenly dip at an angle of about $40^{\circ}$. Egeria Gulch has been eroded on these tilted beds along one of the weaker shaly zones.

At its northern end Twentymile basin is extended to the north in a narrowing synclinal trough. In this vicinity on the lower valley of Trout Creek the eastern border of the field is somewhat complicated by subordinate folds, which are, however; largely confined to the lower part of the Mesavierde formation. The upper strata, including the Twentymile and Trout Creek sandstones, show the influence of this subordinate wrinkling to a much lesser degree. Between Eddy post-office and Steamboat Springs much of the country is covered by a heavy mantle of coarse gravel or cobbles, which in many places completely obscures the eastern rim of the field, but it seems probable that the coal-bearing formation does not extend much beyond the limit shown on the map.

SAGE GREEK ANTICLINE.

From Williams Park, as a center or axis, two folds extend to the north. One has already been described as a portion of the Tow Creek anticline. The other is much shorter, but is the sharper and more conspicuous of the two. This latter is known as the Sage Creek anticline from the name of the stream that has eroded a canyon-like valley for some distance upon the northern end of its axis. This fold extends out into Hayden Valley, but at a point about 5 or 6 miles south and a little east of the village of Hayden, it plunges suddenly and is lost from sight. It is important as it brings to outcrop all the coals of the Mesaverde formation, and makes them readily accessible from Hayden Valley. It is more fully described on pages $54-56$.

\section{FOLDS WEST OF HAYDEN.}

Near Craig and west of the meridian of Craig certain gentle folds, while not greatly distorting the structure, have produced noteworthy topographic effects and have largely influenced the outcrop of the coal groups. A gentle arching of the strata at Craig has brought the uppermost coal seams to the surface. Another low dome of the 
strata, with apparently greatest elongation on an east-west axis, brings the coal-bearing strata to the surface in a small area about 3 miles southwest of Craig. As this latter is near the broad open valley known as "Big Bottom," it will be spoken of as the Big Bottom anticline. Near Williams Fork warping of the strata has given rise to considerable irregularity. The most marked fold is a syncline with an axis lying directly through Round Bottom (Canyon Park of the Hayden Survey), and approximately parallel to the main axis of the Yampa field. Details of the folds south of Williams Fork in the vicinity of Hamilton have not been completely worked out, but it is known that they are such as to continue the area of coal-bearingr rocks south of Williams Fork near this point.

\section{FAULTS.}

Owing to the prevailing misinterpretation of the use of the term fault, noted among local residents and prospectors in the Yampa field during the prosecution of the present survey, it may be well to explain the established usage of the word. The definition given in Dana's Manual of Geology $y^{a}$ is "Faults are displacements along fractures. There may be a few inches or less of displacement or a few feet, but the larger faults of mountain-making regions are sometimes 10,000 to 20,000 feet." A fold in the strata without a break and displacement of the two sides is not a fault. A fold is frequently eroded, so that the edges of the harder layers stand out as cliffs, as though they had been broken, but if the discontinuity of the ledges is the result of erosion, and not of displacement or movements within the crust of the earth, it can not be termed a fault.

Within the area of the coal-bearing rocks the structure of the field is influenced only in a very subordinate way by faults. Local slip. or breaks in the strata were noted at a number of points, but with two or three exceptions these disturbances were not of sufficient magnitude to produce any marked effect on the distribution or general attituds of the strata.

The chief exception to the general statement is in the vicinity of Eddy post-office. About 1 to 2 miles southeast of this place the hogbacks of the lower coal group, together with the coal seams themselves, have apparently been markedly displaced. South of this point along Oak Creek these rocks are tilted in regular structure, having a north-south trend and a uniform dip to the west. From the Eddy district northward the trend changes abruptly toward the northwest and the dips become variable. At the elbow of this bend the strata are apparently much buckled and the seeming discontinuity of the lower coal strata strongly suggests faulting on a considerable

a Dana, Jas. D., Manual of Geology, fourth ed., 1895, p. 107. 
scale: Unfortunately a mask of gravels of Glacial or earlier age covers the exposures of a large part of the lower Mesaverde series at this point and the situation can not be clearly determined. Minor faults were noted with certainty in the rocks along Trout Creek below Eddy. One of these can be seen in the old placer working on the Jones ranch and one occurs in the high mesa on the west side of Trout Creek, about 2 miles below the crossing of the road from Twentymile Park to Steamboat Springs.

An apparent break in the strata was noted on the river a short distance east of Hamilton post-office, but the exposure is not such as to make the relations clear. It is thought that the displacement does not exceed 100 to 200 feet at the most.

In Foidel Canyon the long escarpment of the Twentymile sandstone member shows a single displacement just south of the road that crosses to Dunkley. The ledge is apparently broken along an approximately northwest-southeast line with the block on the south downthrown about 75 feet. A similar occurrence was noted in the canyon of Middle Creek just east of Foidel Canyon.

\section{ROCKS.}

The greater part of the coal-bearing strata of Colorado is of Upper Cretaceous age, the Montana and Laramie formations containing most of the valuable coals. It has been the popular impression that the coals of the Rocky Mountain fields are contained almost wholly in the Laramie formation, and many statements have been published to this effect, but the geologic explorations that have been carried on in these fields within the past few years have shown that a considerable amount of the valuable coal is older than the Laramie. Owing to the present confusion in the names of the geologic formations of the Yampa and adjacent coal fields, a brief account is given of the manner in which these names were originally applied to the strata west of the Rocky Mountains and to those of the Yampa field in particular.

\section{PREVIOUS STUDY.}

The mapping of the rock formations in the vicinity of the Yampa field fell within the province of the geologists of both the King and the Hayden surveys. These investigators adopted the classification for the Cretaceous strata that had been previously established from measurements and study of the rocks in the upper Missouri River region by Meek and Hayden. In that region the classification was adopted mainly on lithologic grounds, and seemed satisfactory as applied over a considerable area of western Cretaceous rocks. Below the Laramie each of the major lithologic groups thus established was

Bull. $297-06-2$ 
found to contain a distinct and characteristic fauna. In brief, the grouping there adopted is summarized in the following table:

Classification and nomenclature adopted in previous surveys.

Tertiary.

$$
\text { Cretaceous. }\left\{\begin{array}{l}
\text { 1. Laramie. } \\
\text { 2. Fox Hills. } \\
\text { 3. Pierre. } \\
\text { 4. Niobrara. } \\
\text { 5. Benton. } \\
6 . \text { Dakota. }
\end{array}\right\} \text { Colorado group. }
$$

In the early surveys of northwestern Colorado it was found quite impossible to recognize the established groups of the Cretaceous system either by lithologic or faunal breaks. Distinct lithologic groups were clearly present, but as these did not conform to the established groups of the Meek and Hayden section they were in part ignored and in part misinterpreted. In the Yampa district several formations are distinct and persistent throughout the entire field, but the arbitrary boundaries that the early investigators adopted for the purposes of description and mapping were placed at indefinite horizons within the natural groups, to the confusion of all succeeding geologic work that has attempted comparison or correlation with this field. Doctor White, in the Tenth Annual Report of the Hayden Survey, which deals with the Yampa and White River valleys, says: "All the groups of strata that are referred to the Cretaceous period in this report are, within this district, not only strictly conformable with each other as regards their stratification, but I have never been able to fix upon a plane of demarkation between any of them with entire precision."

The difficulty that was experienced in applying the classification of the Meek and Hayden section to the Cretaceous rocks of the territory west of the Rocky Mountains was further augmented by the introduction of what was then assumed to be the Laramie problem, which had already proved a fruitful source of doubt and dispute in other fields. In fact, to the present day the limits of the Laramie formation have been the subject of much discussion, and even now can not be said to be well defined. It is generally conceded that this formation should include those beds that were laid down during the transition from the marine or salt-water conditions of Cretaceous time to the freshwater conditions of fluviatile or lacustrine deposition in Tertiary time. While fossils denoting life under fresh-water or brackish conditions occur far down in the Cretaceous system, and while it is assumed that the vegetation represented in the coal seams required fresh and shallow water for their formation, the limit accepted as marking the end of essentially marine conditions is not drawn until this change from marine to brackish-water life becomes a predominating feature of the beds. In brief, the Laramie is supposed to 
U. S. GEOLOGICAL SURVEY

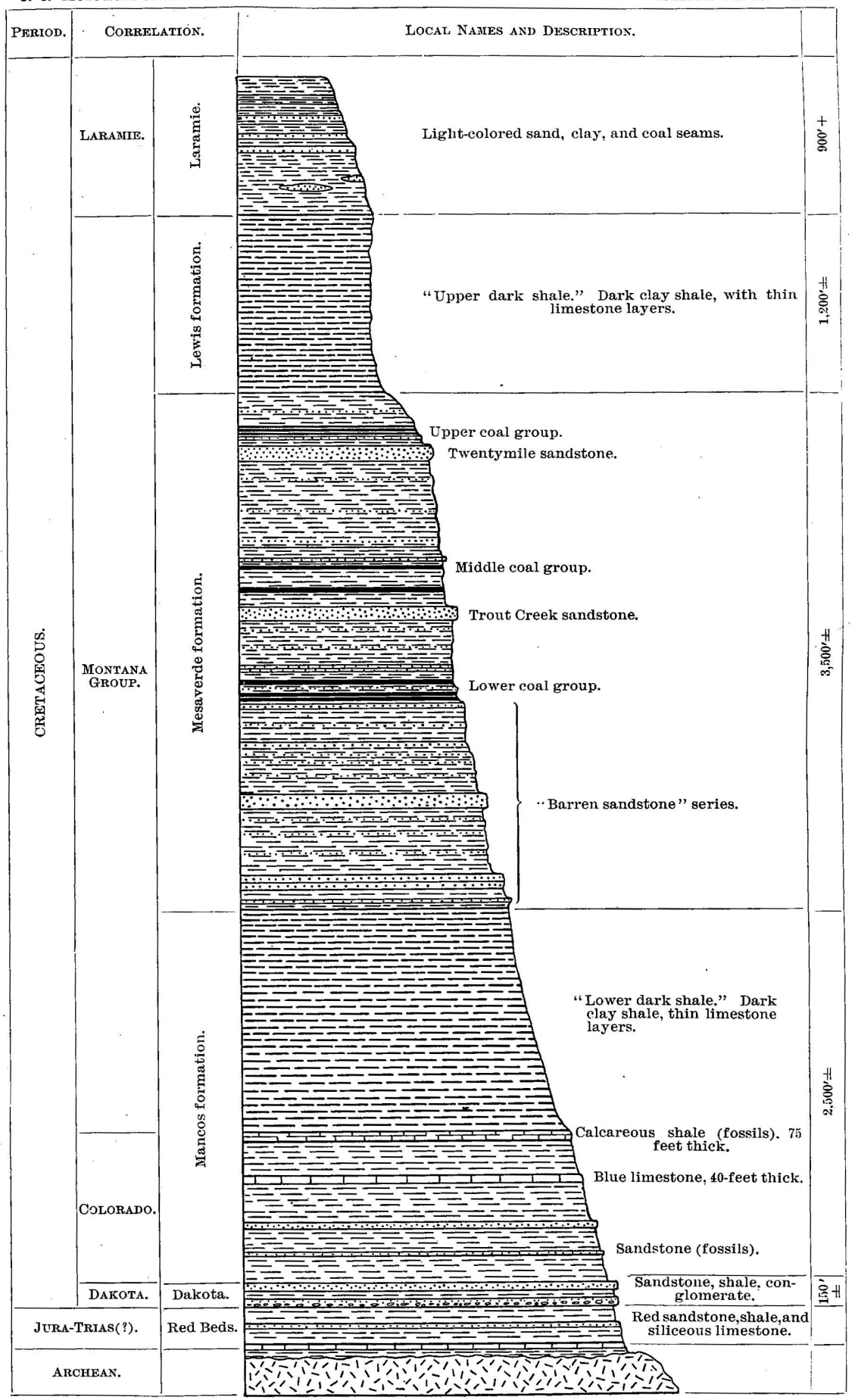

GENERAL STRATIGRAPHIC SECTION FOR YAMPA COAL FIELD, COLORADO. 

include the uppermost alternating brackish to fresh water beds of the Cretaceous period, and to be bounded above by the Tertiary beds of wholly fresh-water origin and below by the beds of the Montana group or its equivalent, which contain fossils of distinct and essentially marine types.

As has been previously stated, it has been the popular impression that the coals of the Rocky Mountain fields are contained almost wholly in the Laramie formation. Much of the early confusion of the Laramie with older formations was the direct result of the assumption on the part of geologists that, with the exception of a few coal seams discovered in or about the horizon of the Dakota formation, all beds containing coal must be classed in the Laramie. In fact, the lower limit of the Laramie rocks as mapped by the King and Hayden surveys was arbitrarily drawn just below the horizon of the lowest recognized coal seam. In the later writings and reports of geologists and mining engineers this assertion has been repeated until it has come to be popularly accepted as established. Foremost among these publications are the writings of Mr. R. C. Hills, who is a recognized authority on Colorado coal fields and who has contributed much valuable information in his descriptions of them.

Below the Laramie and above the Dakota the succession of formations as summarized in the foregoing table is not applicable to the Yampa field except in a most general and indefinite way. In the Montana group the Fox Hills sandstone and Pierre shale are not found as distinct formation or lithologic units, and similarly the Colorado group can not be said to be composed of the Niobrara limestone and Benton shale as distinguished in other fields. Moreover, the line between the Montana and Colorado groups also becomes an indefinite or arbitrary boundary as the distinction between Pierre and Niobrara is lost. There is, however, a certain fossil fauna which has been recognized as characteristic of the Montana formation, and similarly a lower fauna which is as characteristic of the Colorado. It is, however, more convenient and logical to drop the grouping as Colorado and Montana and adopt a new basis for subdivision of the combined stratigraphic interval thus represented. This has already been done by the geologists who have worked in southwestern Colorado, ${ }^{a}$ where the succession shows such marked similarity to that of the Yampa field that the names there adopted have been incorporated in this report and are shown in the general stratigraphic column represented in Pl. II.

This plate explains the relation of Montana and Colorado groups to the formations that are described in the report. It will be noted that the Mesaverde and Fox Hills formations both constitute a part a Cross, Whitman, Description of the La Plata district: Geologic Atlas U. S., folio 60, U. S. Geol.
Survey, 1899. 
of the Montana group, but that the Mesaverde occurs lower in the series than the Fox Hills, for which it was mistaken by the Hayden and King surveys. In some fields the Fox Hills lies normally at the top of the Montana, and may even be indistinguishable in the character of its rocks from the Laramie above, while in the Yampa field the thick Lewis shale separates the Mesaverde from the Laramie.

\section{STRATIGRAPHY.}

The coal-bearing rocks of the Yampa field are found in the:Mesaverde formation and in the Laramie. Between the coal field proper and the Park Range on the east are outcrops of older Mesozoic rocks, the entire section in and adjacent to the coal field being as follow's (Pl. II) :

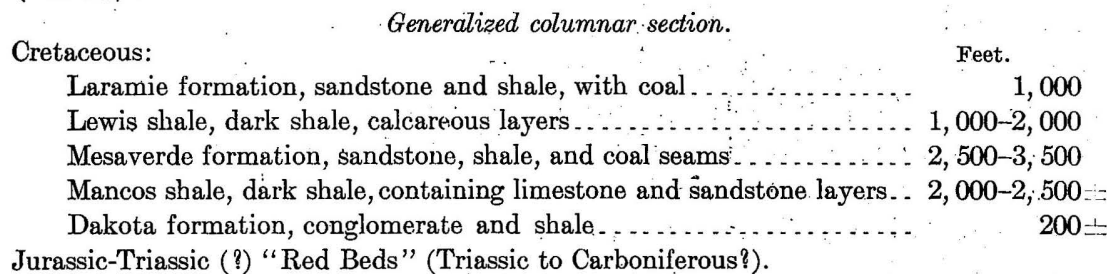
Archean (ancient crystalline and metamorphic rocks).

The rocks below the coal-bearing group were not studied in great detail. In a preliminary examination to determine the stratigraphic relations of the coal measures the lower sedimentary formations were crossed and examined along a few sections between Yampa and Steamboat Springs and also in the vicinity of Hahns Peak. A geologic map is published herewith, showing the distribution of formations both north and south of the Yampa field (Pl. III). This has been compiled from the results of the present survey, from the Hayden Atlas of Colorado, and in lesser part from the King Atlas of the Fortieth Parallel Exploration.

\section{DESCRIPTION OF FORMATIONS.}

\section{ARCHEAN.}

The main mass of the Park Range is a vast complex of granitic rocks, gneisses, and schists which have been hitherto referred to the Archean. They are probably largely of igneous origin, although some of the gneisses and schists may represent ancient and muchaltered sediments. These rocks were observed in crossing the Park Range on the stage road leading from Sulphur Springs to "Yampa. They were also observed at numerous other points along the eastern margin of the territory mapped, and débris of these rocks is scattered throughout the valley of Yampa River in the form of rounded bowlders and pebbles. 

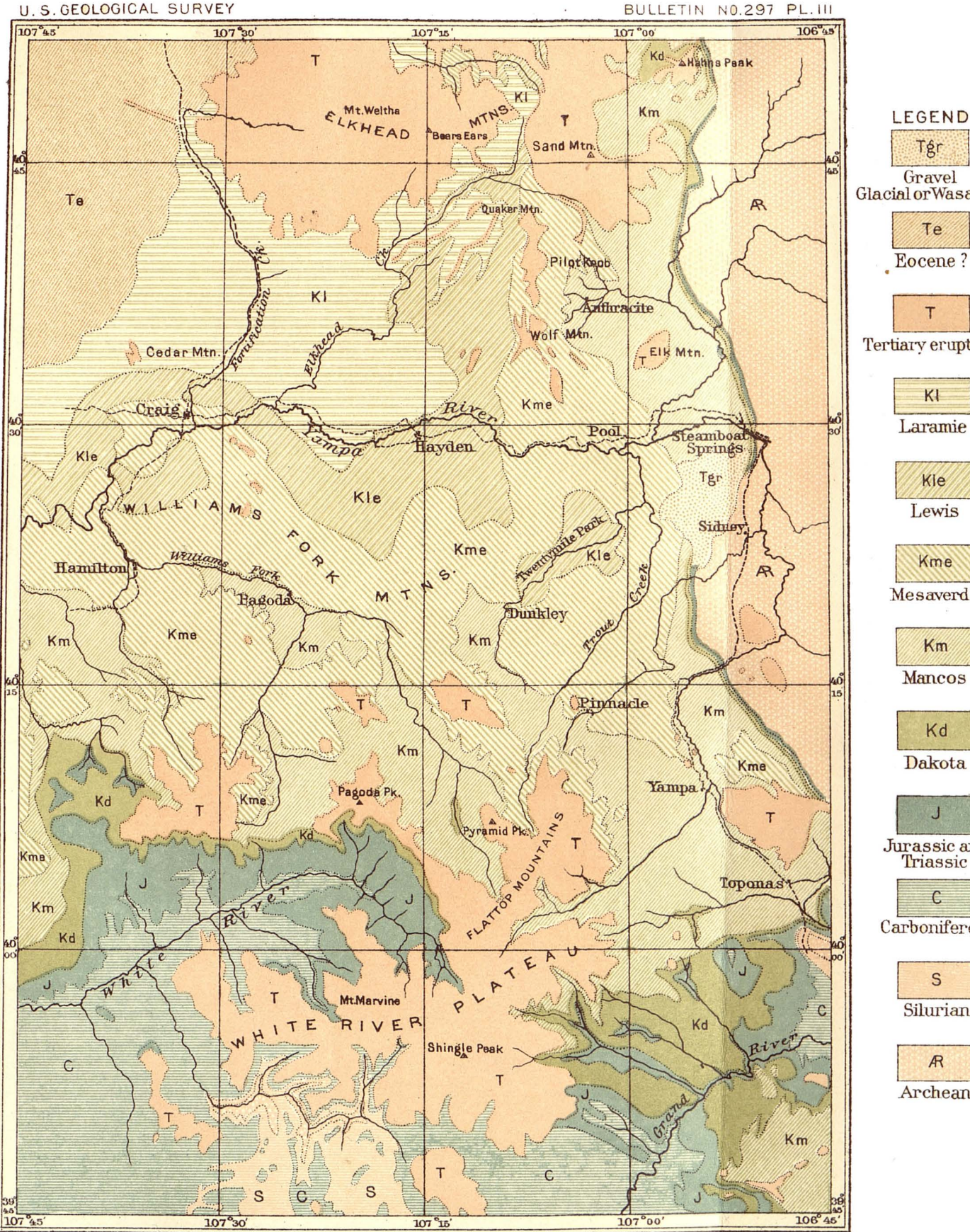

Glaciol orWasatch?

\section{Te \\ Eocene?}

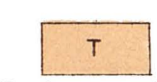

Tertiary eruptives
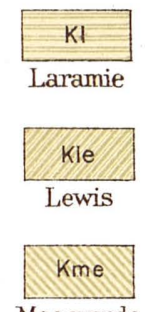

Mesaverde
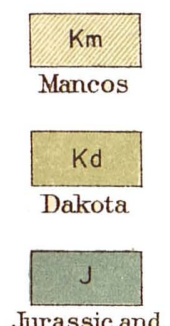

Jurassic and

Triassic
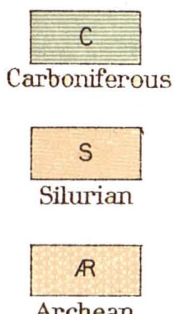

GEOLOGIC MAP OF YAMPA COAL FIELD AND VICINITY, COLORAD0

Compiled from the Hayden and King Atlases, revised to fit the present survey

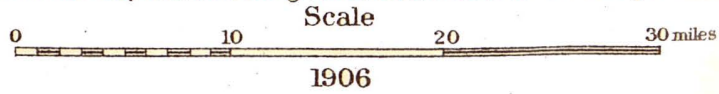



PRE-CRETACEOUS ROCKS.

Between the rocks of the Archean complex described above and the ledges of the Dakota sandstone there are strata of variable and undetermined thickness, usually much disturbed and crushed by faulting and folding. In this interval are beds showing the brightred color which characterizes the so-called "Red Beds" in many parts of the West. Thinner beds also occur of a hard blue siliceous limestone filled with a fine network of white calcite seams, yielding a bright-red or pink clay soil. The siliceous limestone and accompanying beds of viariegated shale are thought to represent the Jurassic. In the vicinity of Hahns Peak a compact blue limestone almost immediately underfying the Dakota is thought also to be of Jurassic age. "The "Red 'Beds." are supposed to be of Triassic age or in part older.

\section{CRETACEOUS.}

DAKOTA FORMATION.

The next formation showing in outcrop is the Dakota formation. It is composed in its upper portion of a white or gray even-grained sandstone and quartzite, containing also beds of sandy shale or slabby sandstone. In its lower portion there was found at places a conglomerate characterized by well-rounded pebbles of exceedingly hard material, among which may be readily recognized white and gray quartz and a dark flint. The following measurement of its thickness was obtamed from the record of the Minnie D shaft, Columbine, Colo., which was furnished by Mr. Daniel Stukey. This shaft was sunk through the formation where it lies approximately horizontal and gave a thiokness of 157 feet

Record of Minnie D shaft, Columbine, Colo.

\begin{tabular}{|c|c|c|c|}
\hline Systèm. & Formation. & Character. & Thickness. \\
\hline $\begin{array}{c}\text { Cretaceous :... } \\
\text { Jurassic (?) ... }\end{array}$ & $\left\{\begin{array}{l}\text { Benton (?) } \\
\text { Dakota } \ldots\end{array}\right.$ & 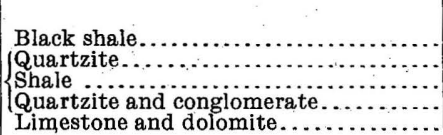 & $\begin{array}{r}\text { Feet. } \\
25 \\
42 \\
80 \\
35 \\
143\end{array}$ \\
\hline & & & 325 \\
\hline
\end{tabular}

All of these rockswere found in the dump, but the shaft was not accessible when visited.

The Dakota formation shows at intervals along the lower slopes of the Park Range on the east of Yampa field. Just below or west of the village of Steamboat Springs, Yampa River cuts through the ledges of this sandstone, which are sharply upturned; dipping $30^{\circ}$ to 
$40^{\circ} \mathrm{W}$. On the ridge just north of this point the sandstone is overturned, the ledges dipping back to the east. The distribution of the Dakota sandstone is outlined on the general geologic map (Pl. III).

\section{MANCOS SHALE.}

The shale which lies above the Dakota sandstone is here referred to as the Mancos shale, because it closely resembles the Mancos shale of southwestern Colorado and occupies a similar position above the Dakota. This formation was named by Mr. Whitman Cross from its occurrence near the town of Mancos in Montezuma County, where the formation is characteristically developed in the Mancos Valley. ${ }^{a}$ The names of this and the two succeeding formations are taken from the same general region. The Mancos shale includes essentially the same interval that was mapped as the Colorado group by the King and Hayden surveys in the Yampa field, although as more accurately defined only the lower portion of the Mancos shale should be correlated with the Colorado group.

Fossils were found at several horizons within this formation, among which Dr. T. W. Stanton identified Ostrea congesta Conrad, Inoceramus (fragments), and Lingula sp. At one locality east of Eddy postoffice a fossiliferous horizon about 200 feet above the Dakota sandstone contains Benton forms. About 600 feet higher a calcareous shale horizon containing characteristic Niobrara forms was found. Thus the division plane between the Benton and Niobrara occurs somewhere between these two horizons, but there is no lithologic break or change in this interval and the division can be made only upon paleontologic grounds. Even if sufficient fossil evidence were at hand to make the division it is extremely doubtful if it would serve any useful purpose, as no one without paleontologic training could appreciate its value when drawn.

The outcrop of the Mancos shale is usually marked by open valleys bounded on the one side by ridges of the Dakota formation and on the other by ridges of the overlying Mesaverde formation (Pl. IV, $A$ ). Where the structure is a simple monoclinal dip away from the mountains, as for instance in the valley just east of Oak Creek, this shale forms a long. narrow strike valley, but where complicated by minor folds, as in Yampa Valley below Steamboat Springs, the shale valley is much broader.

\section{MESAVERDE FORMATION.}

General description.-The name "Mesa Verde group" was applied by W. H. Holmes ${ }^{b}$ to the series of sandstone and shales forming the Mesa Verde in southwestern Colorado. The name Mesaverde forma-

$a$ Description of the Telluride district: Geologic Atlas U. S., folio 57, U. S. Geol. Survey, 1899; see also folio 60

$b$ U. S. Geol. and Geog. Surv. Terr., 1875, pl. 35, p. 244. 


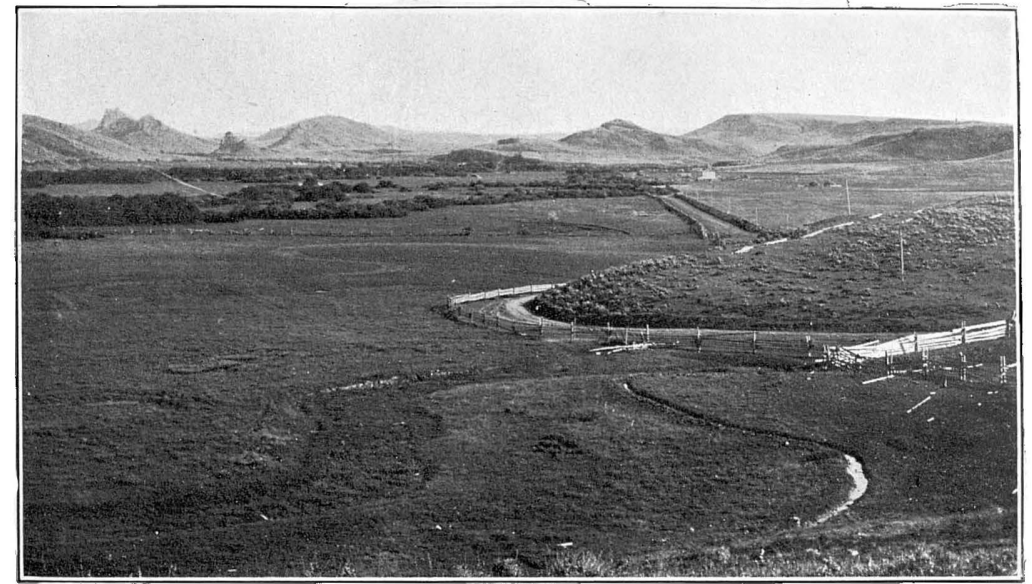

A. YAMPA VALLEY AND VOLCANIC STOCKS NORTH OF YAMPA.

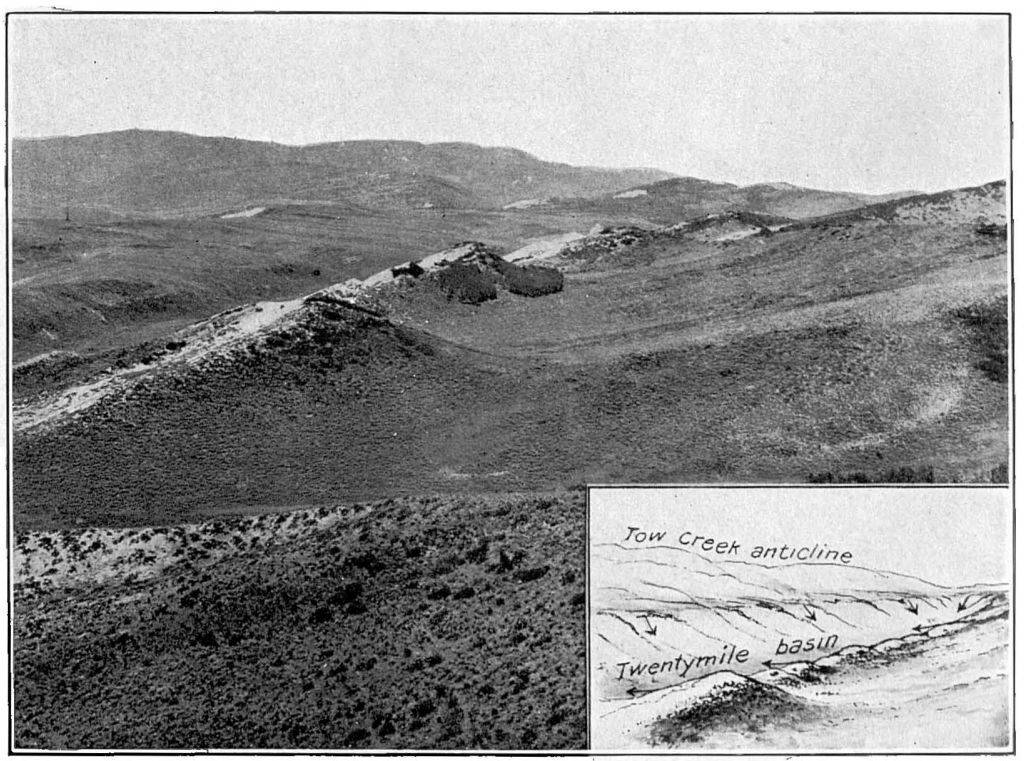

B. LEDGES OF TWENTYMILE SANDSTONE AT NORTHERN END-OF TWENTYMILE BASIN. 

tion, instead of group, was later adopted by Mr. Whitman Cross, who was engaged in detailed areal mapping in the same region. ${ }^{a}$ In the Yampa field the formation is apparently anclogous to that of the type locality both in character of its constituent members, in its position between two great clay-shale groups, and in the fossils that it contains. In the Yampa field, however, it attains a thickness of 2,500 to $3 ; 500$ feet, while in southern Colorado its maximum development is about 1,000 feet.

As compared with the formations on the east side of the Rocky Mountains the age of these beds may be called Pierre-Fox Hills, the fauna of the shales resembling that of the Pierre, while the fauna of the sandstones is more like that of the Fox Hills. This formation in the Yampa field is composed of sandstone, shale, $c$ nd coal beds, but the coals are not equally distributed throughout the formation. The more prominent members, such as sandstones and cocl beds, occur in groups, and some of these groups and even individual beds can be traced for long distances. The coal seams fall naturally into three groups, each ranging through a vertical distance of from 200 to 400 feet, the several groups being separated by from 500 to 1,000 feet of barren sandstone and shale. These groups are continuous, though individual coal beds vary in thickness from place to place, and can rarely be identified over distances exceeding a few miles. There are a few massive sandstone strata which are essentially continuous throughout the field, but for the most part individual beds, however massive or prominent locally; can not be traced far. The coal-bearing rocks may be grouped $\varepsilon s$ follows:

\section{Generalized section of the Mesaverde formation.}

Sandstones (occasionally massive) and shales, containing coal, especially in upper

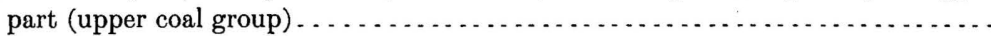

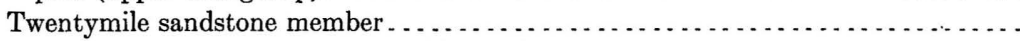

Weak sandstones and shales, with frequently a prominent ledge-making yellow sandstone about 250 feet from the top . . . . . . . . . . . . . . . . . . . . . . .

Sandstones (occasionally massive), shales, and coals of the middle group. . . . . . . .

Trout Creek sandstone member. . . . . . . . . . . . . . . . . . . . . . . . . . .

Shales and weak sandstones, with few massive beds, containing in the lower part the upper seams of the lower group of coals . . . . . . . . . . . . . . . . . . . .

Massive sandstone, with subordinate shaly sandstones and shales, containing near the top the lower seams of the lower group of coals . . . . . . . . . . . . . . .

Slabby or shaly sandstones with some shales, frequently having greater strength at 2 or 3 horizons; on erosion giving rise to hogbacks . . . . . . . . . . . . . . $\quad 750$

Since this formation contains most of the important coal beds of the field, it will be described in considerable detail. 
Lower coal group and associated strata.-The position of the lower coal group is somewhat clearly indicated by its relation to the underlying thick group of massive sandstones, which form conspicuous topographic features throughout the field. These basal sandstones outcrop in prominent scarps on the southern side of the field, facing south toward White River Plateau and overlooking the valley of Williams Fork and Axial Basin. In most places erosion at the foot of the scarp has cut into the dark shale which underlies the coal group. At the base of the group there can be traced with remarkable uniformity two ridges or hogbacks due to the stronger zones in the slabby sandstones which underlie the more massive strata. Similar relations appear on the eastern boundary of the field, where the cliffs face eastward, overlooking Yampa River, Oak Creek, lower Trout Creek, Elk River, and the valleys draining into Deep Creek. These sandstones are frequently referred to descriptively as the "barren sandstones," though within the upper 200 feet of this portion of the series there may be as many as three workable coal seams belonging to the lower group (see Pl. V).

In the next 400 feet strong ledge-making sandstones are few and local. This zone is composed of softer sandstones and shales, and where the beds are steeply upturned; as in Egeria Gulch (the southeast tributary of Trout Creek, followed by the road from Pallas), is marked by a valley. Where the beds are more nearly horizontal the position of this group is marked by a relatively gentle slope or platform separating the bold cliffs above and below. These beds include the upper members of the lower coal group. The following section, from a locality $2 \frac{1}{2}$ miles east of Pagoda post-office, illustrates the general features and is fairly representative of the group:

Section including the lower coal group, $2 \frac{1}{2}$ miles east of Pagoda post-office.

1. Sandstone and shale.

2. Sandstone and shale, much of which is colored red by burning of coal seams

3. Massive sandstone . . . . . . . . . . . .............................. 25

4. Thin sandstones and shales, containing three coal beds of unmeasured thickness

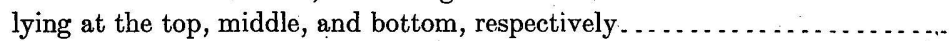

5. Massive sandstone .............................................. 35

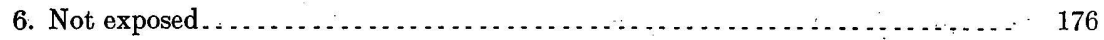

7. Thin sandstones and shales with three strong sandstone beds in the upper half. $\quad 180$

8. Group of massive sandstones................................. 149

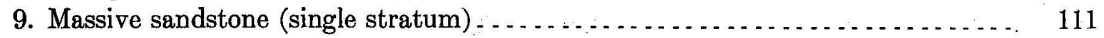

10. Débris-covered slope, probably alternating sandstone and shale .......... 371

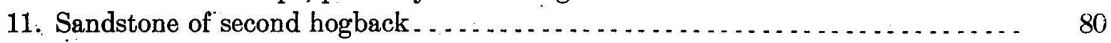

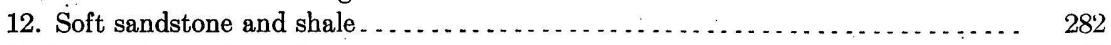

13. Lower hogback sandstone. . . . . . . . . . . . . . . . . . . . . 50

Dark shale (Mancos shale).

Thickness above the Mancos shale........................... $\overline{1,928}$ 


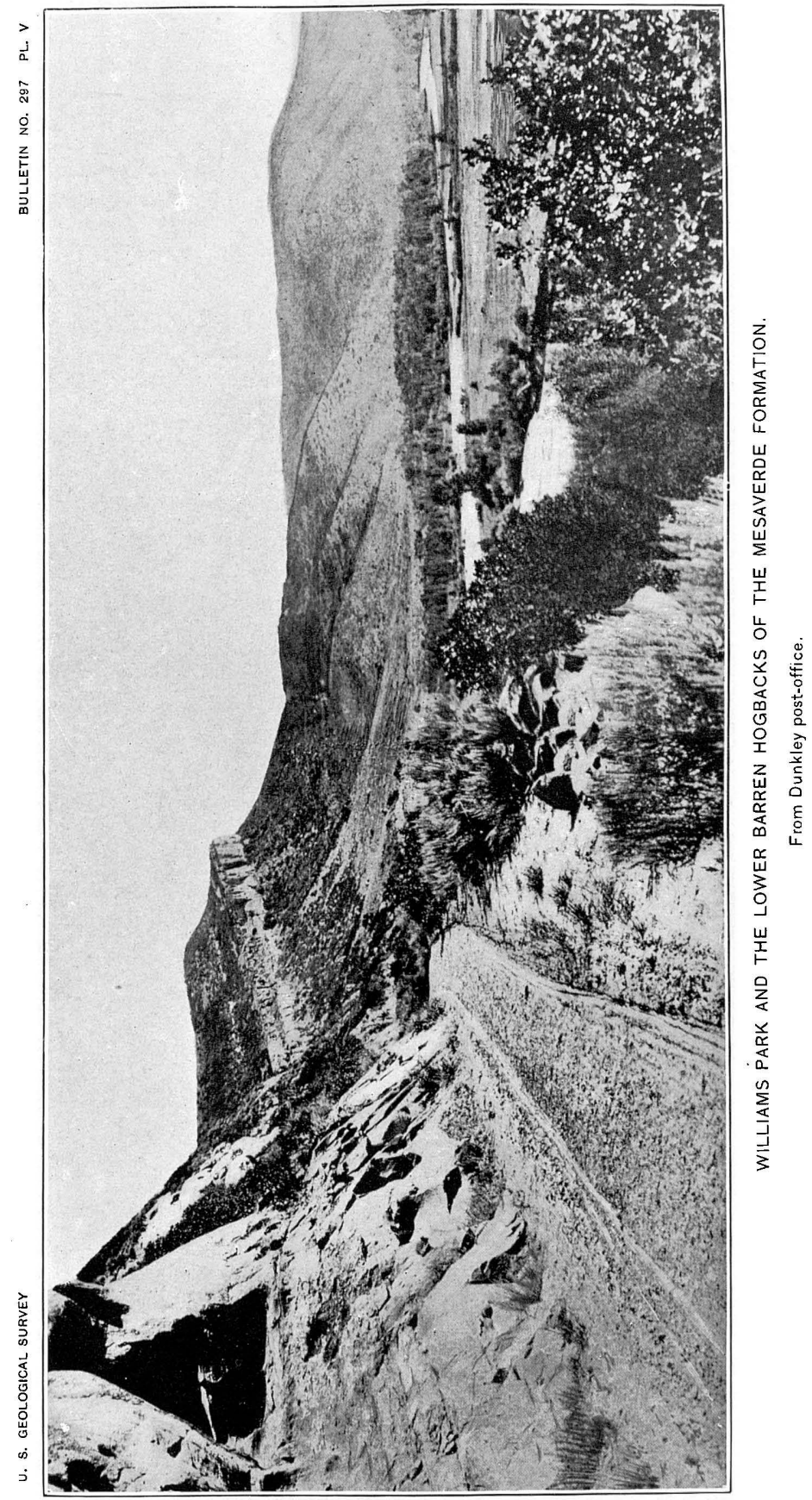


The weaker beds associated with the coal are commonly covered with talus or soil and are rarely well exposed. The following section, measured in the southeast corner of the field, doubtless represents their general character:

Section 8 miles northwest of Yampa, showing the general character of many of the beds between the ledge-making sandstones of the Mesaverde formation.

1. Coal

Feet. Inches.

2. Blue clay

3. Coal

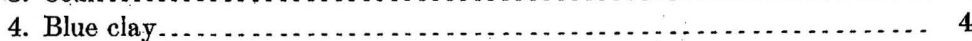

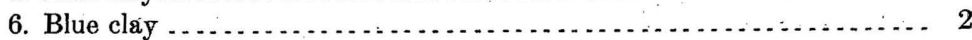

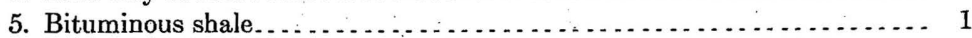

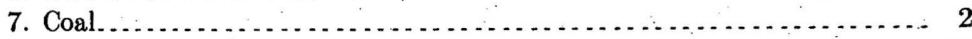

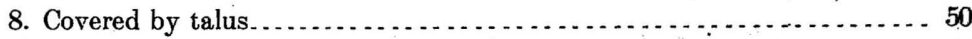

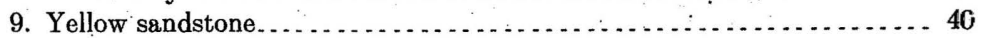

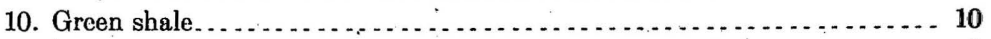

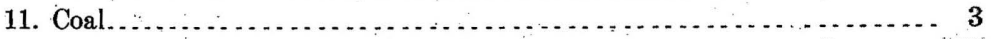

12. Massive, soft, coarse greenish sandstone ... . . $\ldots \ldots \ldots \ldots \ldots$

13. Greenish sandstone with interbedded shales $\ldots \ldots \ldots \ldots \ldots \ldots \ldots \ldots \ldots$

14. Coarse green sandstone.......................... 5

15. Coarse sandstone interbedded with clay shale $\ldots \ldots \ldots \ldots \ldots \ldots \ldots \ldots$

16. Carbonaceous clay........................................... 1

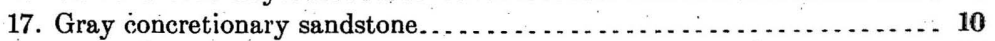

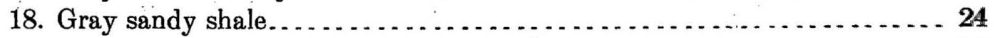

19. Shale and sandstone with concretionary structure $\ldots \ldots \ldots \ldots \ldots \ldots \ldots . . . .38$

20. Dark shale, sandy in places. . . . . . .

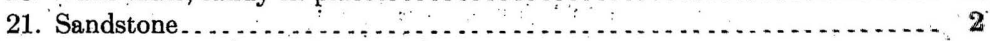

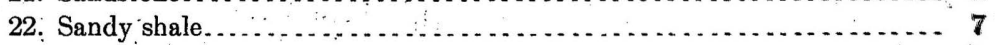

23. Sandstone .

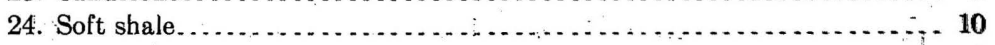

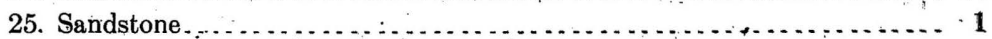

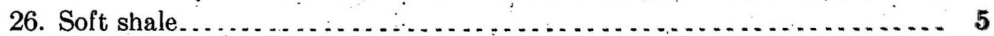

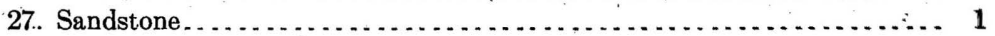

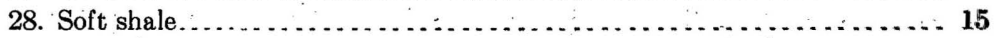

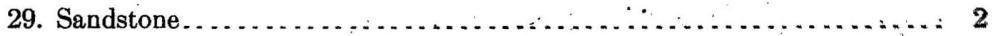

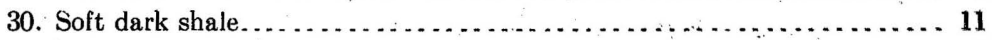

31. Gray shaly sandstone................

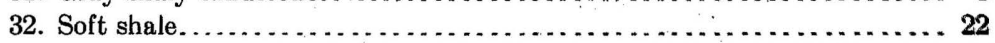

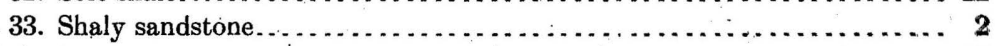

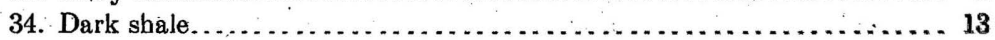

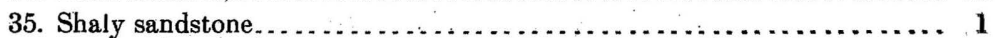

36: Interbedded brown shale and sandstone........................

454

2

As indicated above, the coal seams of the lower group are commonly found among the upper massive sandstones and in the lower part of the overlying weak sandstones and shales. No general statement can be made concerning the number and thickness of coal seams. In but few localities has prospecting been sufficiently thorough to afford accurate measurements. The following section, therefore, is not given as representative of the field; in fact, it is probable that the average amount 
of coal within the same stratigraphic limits over the whole field would fall considerably below these figures:

Section showing coal seams of the lower coal group at Lay.

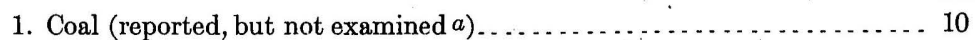

2. Soil-covered slope . . . . . . . . . . . . . 60

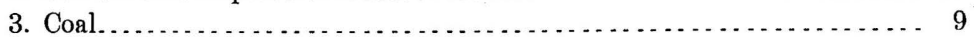

4. Bone . . . . . . . . . . . . . . . . . . . . . . . . . . . . 1

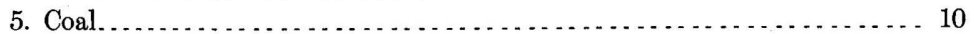

6. Shale and sandstone......

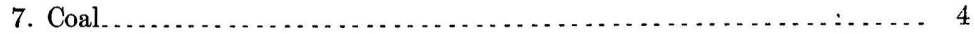

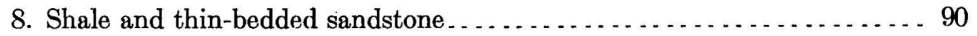

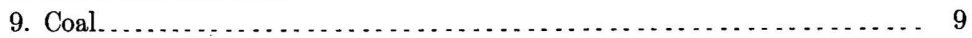

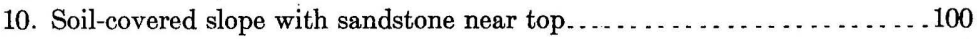

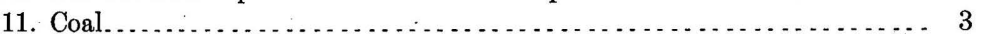

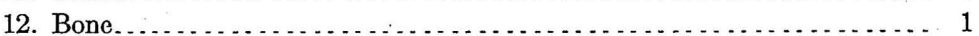

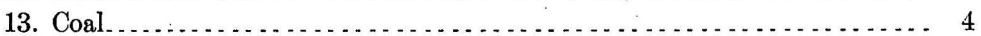

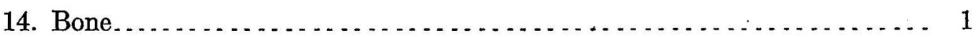

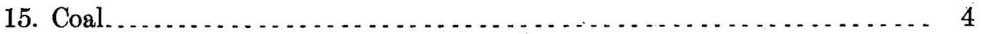

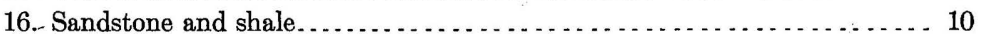

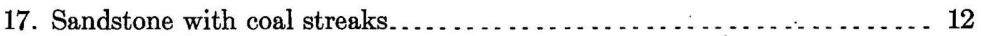

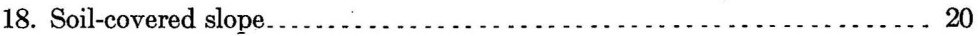

19. Coal (reported, but not examined $a$ ) . . . . . . . . . . . . . . . . . 4

Trout Creek sandstone member.-The prominent ledge-making sandstone found in all parts of the field about midway between the lower and middle coal groups has been called the Trout Creek sandstone member on account of its excellent exposure near Trout Creek on the northeast side of Twentymile Park. The rock is characteristically massive and white and is frequently more than 100 feet thick (Pl. VI). While generally a ridge maker or ledge maker, its exposed surfaces readily weather to a friable condition. Its broad exposures are frequently marked by cracks making polygonal figures a foot or more in diameter. Great concretions and stains due to oxide of iron are also common. Details of its distribution are given later in the descriptions of the various coal districts.

Middle coal group.-The coals of the middle group occur chiefly within an interval of 400 feet above the Trout Creek sandstone. Several workable seams are frequently found; in Sage Creek Canyon the thickest of these is 12 feet. On the west side of this valley, one-half mile west of the Barnes mine, the most detailed section of the middle group was obtained. In its larger features this section accords closely with that taken in Hayden Gulch. The beds marked No. 4 in the Sage Creek section appear in Hayden Gulch and generally throughout the

$a$ Where not otherwise indicated, the measurements of the coal seams named in this section were made by a member of the United States Geological Survey party. The measurements of the two seams marked "Reported, but not examined" were received from Mr. A. G. Wallahan, whose data on all the other seams were found to be correct. 


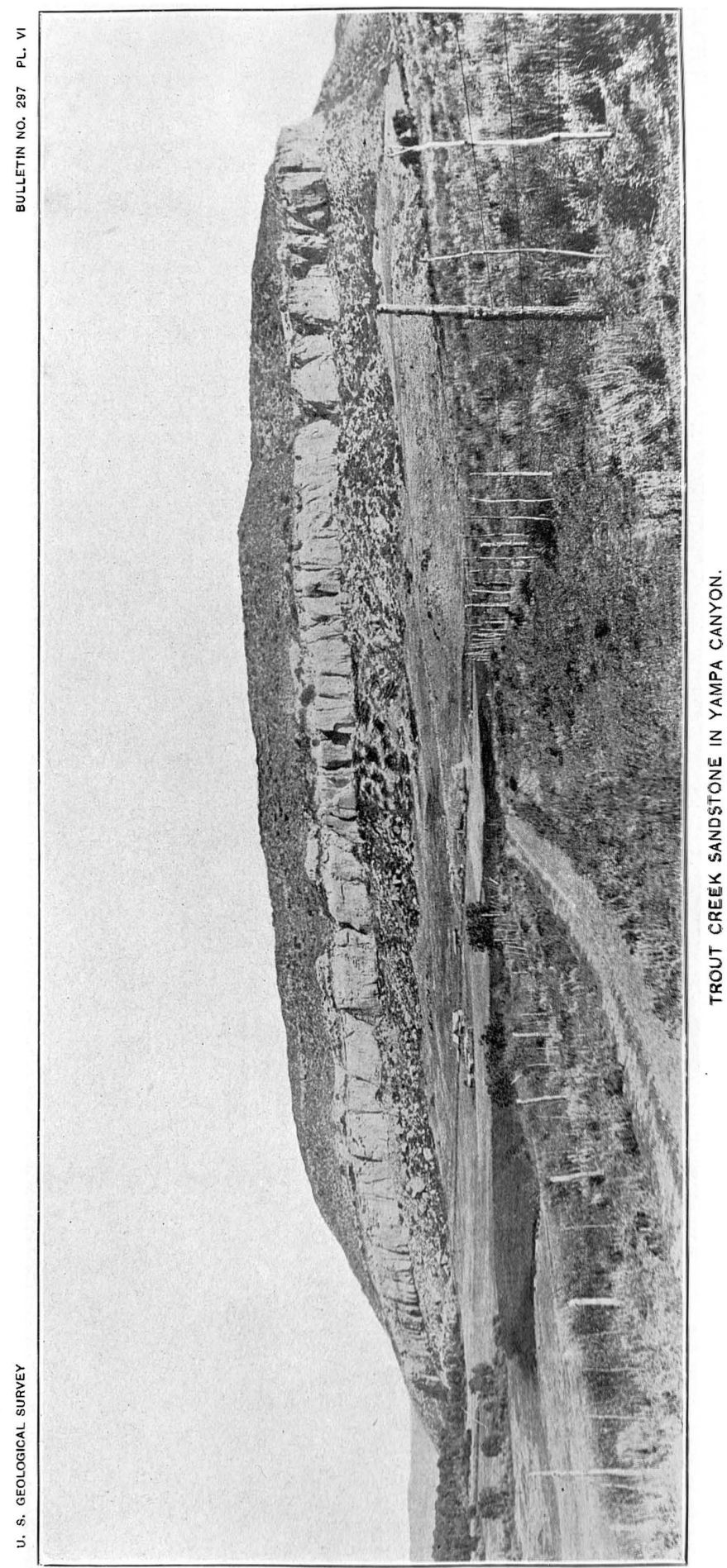



Williams Fork Mountains as a strong yellow sandstone, conspicuous as a ledge maker and almost as persistent as the Trout Creek sandstone member itself.

Section of the middle coal group in Sage Creek Canyon.

1. Talus covered, probably sandstone ............................... 50

2. Soil covered, probably shaly beds .............................. 130

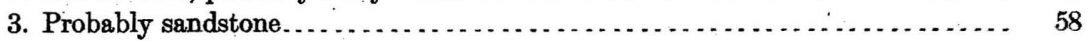

4. Series of four strong sandstones............................... 50

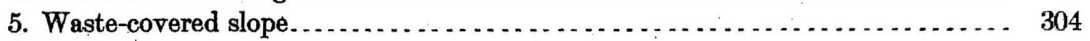

6. Sandstone . . . . . . . . . .

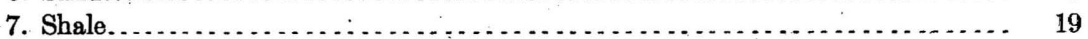

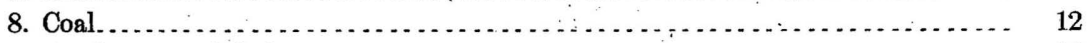

9. Sandstone and shale............................................... 22

10. Thin-bedded sandstone and shale with occasional sandstone beds . . . . . . . . . 110

11. Waste-covered slope ............................................. 10

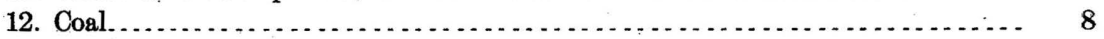

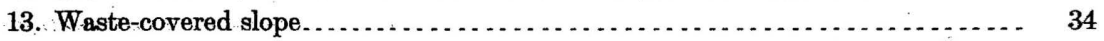

14. Shale....................................................... 2

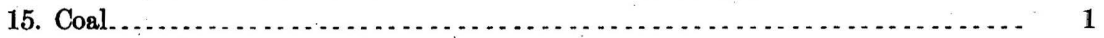

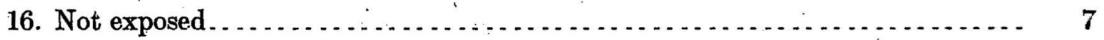

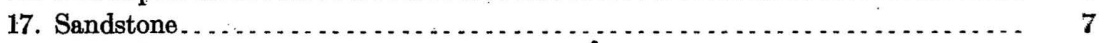

18. Not exposed.................. 22

19. Shaly sandstone.

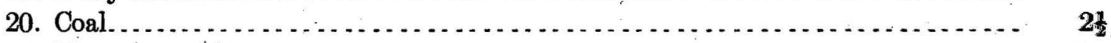

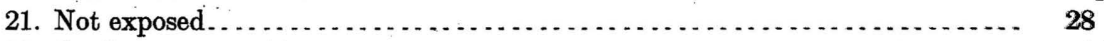

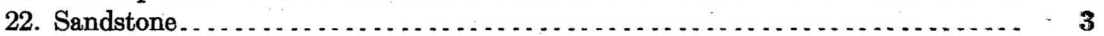

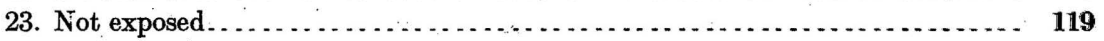

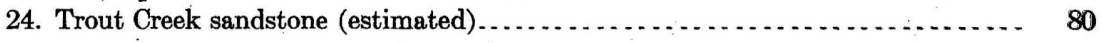

$1,091 \frac{1}{2}$

Toward the western end of the field the barren zone overlying the middle group falls off greatly in thickness. At the same time the coals of the lower group approach close to the base of the Trout Creek sandstone, so that at this place the separation of the coal into three groups depends entirely on the persistence of the prominent sandstones and not on great intervals occupied by bairen strata.

Twentymile sandstone member.-The base of the upper division is marked by a massive sandstone which has been called the Twentymile because of its typical development in and around Twentymile Park (Pl. IV, $B$, p. 22). In places it is a single bed of great thickness, but in other places it consists of a series of massive layers aggregating several hundred feet (Pl. VII). The description of the Trout Creek sandstone member applies also to the Twentymile. Locally, as in Twentymile Park, this formation weathers into conspicuous pinnacles because of the protection afforded to the friable sandstone beneath by large irregular concretions.

Upper coal group.-The coals of the upper group begin just above the Twentymile sandstone, but the thickest beds are generally found 
several hundred feet higher. The section measured in Sage Creek Canyon may be taken as typical of the upper group and the massive sandstone at its base. The higher beds of the upper coal group consist largely of shale and merge into the overlying Lewis shale.

Section of the upper coal group at the mouth of Sage Creek Canyon.

1. Coal . . . . . . . . . . . . . . . . . . . . . . . . . . . . 11

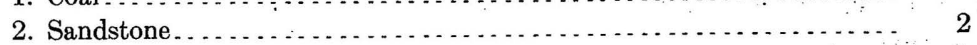

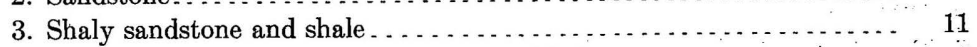

4. Coal, with carbonaceous shale above and below . . . . . 5

5. Sandstone, yellow and iron-stained . . . . . $\ldots \ldots \ldots \ldots$

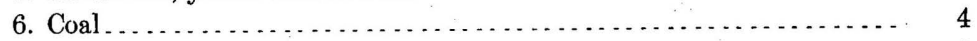

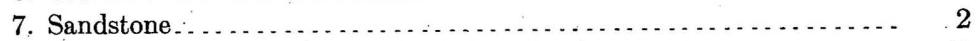

8. Waste-covered slope, probably shale and shaly sandstone $\ldots \ldots \ldots \ldots$

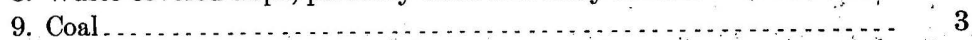

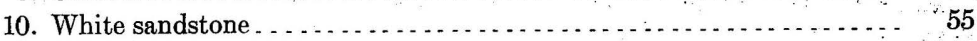

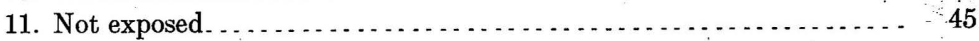

12. Coal indications.

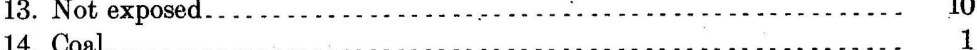

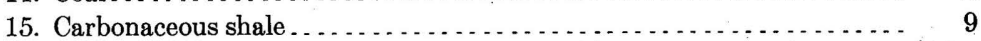

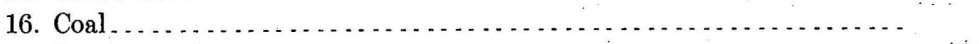

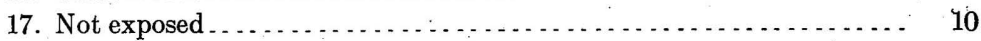

18. Sandstone, with coal indications above $\ldots \ldots \ldots \ldots \ldots \ldots$

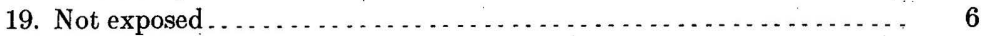

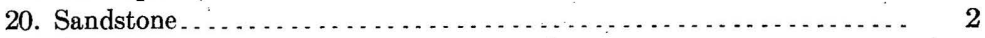

21. Shale, with coal indications below $\ldots . . \ldots \ldots \ldots \ldots \ldots \ldots \ldots . . .2$

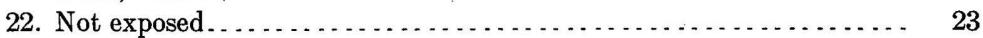

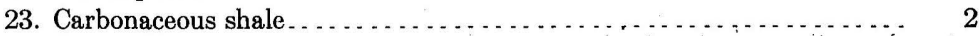

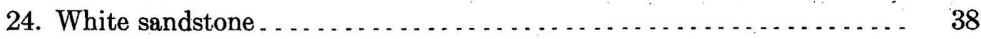

25. Carbonaceous shale, with streak of coal above ............... . 2

26. Thin-bedded dark shale, with occasional beds of sandstone . . . . . . . $\quad 45$

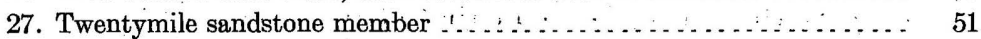

LËIS SHALE.

The thick shale that succeeds the Mesaverd 3 formation was named Lewis shale by Mr. Whitman Cross from its occurrence at Fort Lewis in the La Plata Valley in southwestern Colorado: ${ }^{a}$ The formation in the Yampa field is thought to be entirely analogous to that of the locality cited, and the name is provisionally adopted as in the case of the Mancos shale and Mesaverde formation, in the expectation that future geologic work will definitely establish the correlation between the two. The Lewis shale is somewhat indefinitely bounded below by the lighter colored sandy beds of the Mesaverde, between which and the dark Eewis shale there is a rather rapid transition. "At the top of the Lewis shale there is a similar rapid transition into light sandy strata, which are considered in this report a part of the Lara- 


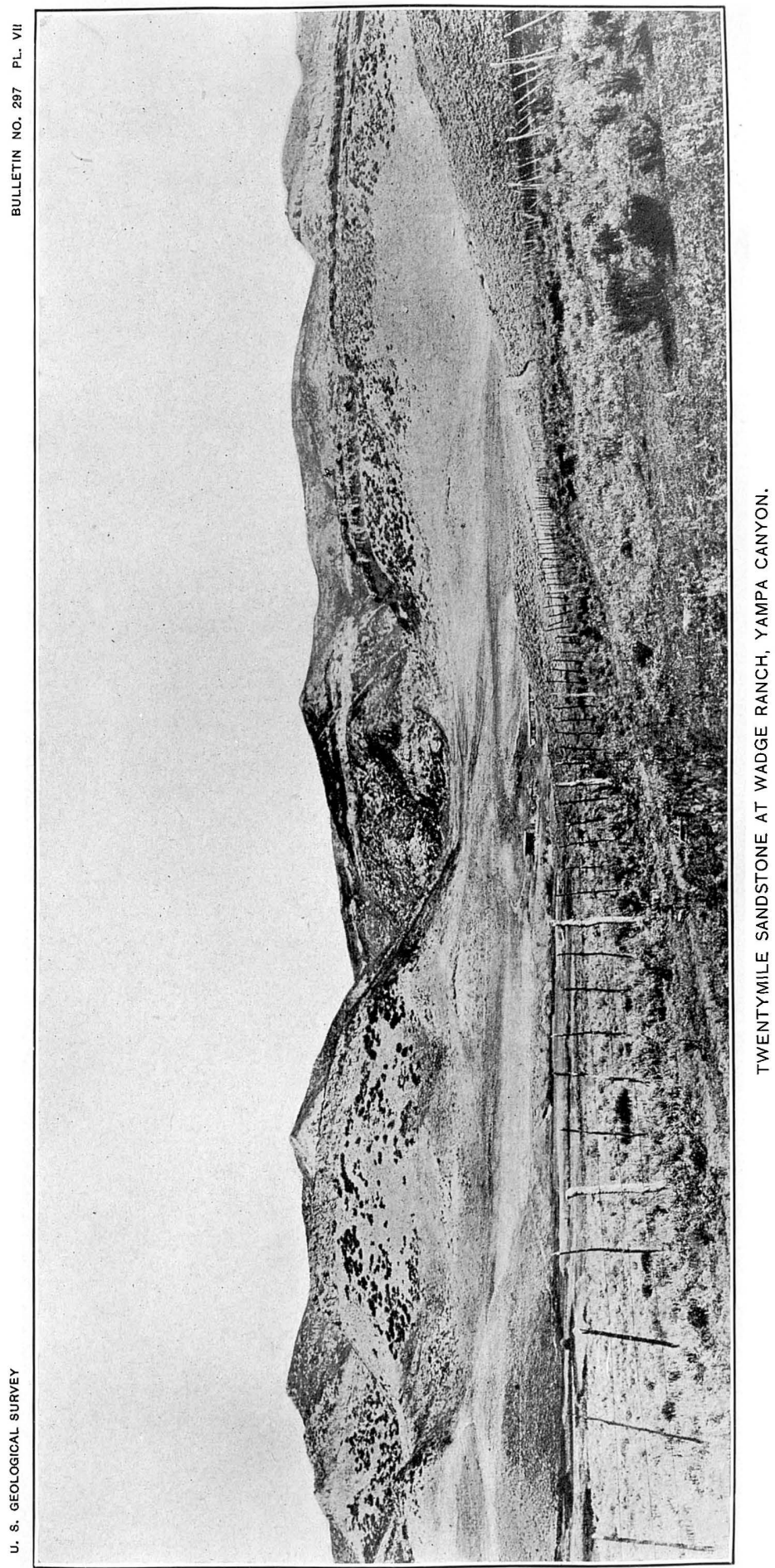


mie formation. The thickness of the Lewis shale is estimated at 1,000 to 2,000 feet, although here, as in the case of the Mancos shale, it was impossible to find a section that would give a reliable measure. This is partly due to minor folds in the shale itself and partly to the poor exposures which generally characterize the outcrop of such a soft formation. The Lewis shale is composed of soft dark-gray or black clay shale, with layers or lenticular beds of a: compact blue limestone and secondary calcite seams. In the soil which forms upon these rocks are found scattered fragments of this limestone and of the calcite; seams: These fragments frequently weather to bright red and yellow on the surface. The more impure oalcareous layers often show cone-in-cone structure.

A few fossils were collected from this formation, among which Scaphites nodosus Owen was identified by Doctor Stanton. In California Park and near the camp known as the "Cottonwoods,". on Dry Fork of Elkhead Creek, the dark shale contains abundant fish scales as well as other fossil forms.

As in the case of the Mancos shale, this formation is usually characterized by open valleys, bounded by sandstone ridges of the Mesaverde formation on one side and usually limited by the escarpment ridges of the Laramie beds on the other.

\section{LARAMIE FORMATION.}

Above the Lewis shale is a thick group of sandstones and shales, generally softer than those of the Mesaverde, and in places unconsolidated. Locally, however, there are massive sandstones very similar in physical characteristics to the Trout Creek and Twentymile sandstone members, as well as to the massive Laramie sandstones of the Denver basin. ${ }^{a}$. The beds also contain seams of subbituminous ${ }^{b}$ coals. Nine hundred feet or more of these rocks appear in the bluffs on the north side of Yampa River near Hayden. At the base of this section near water level these beds rest in apparent conformity upon the Lewis shale, the transition from the dark clay shale into the lighter sandy beds above being apparently rapid. At this point the beds have a uniform low dip to the northwest, this being, as has been explained, approximately the axis of the pitching syncline of the whole Yampa field. The total thickness of thisformation is probably much greater than is shown in this section, as the outcrop extends over a large territory between Yampa River and Elkhead Mountains, dipping away to the northwest. It is supposed that in turn they are covered by beds of Tertiary age.

On the maps of the Fortieth Parallel Survey these beds, including the underlying beds, as far down as the lowest recognized coal seam

$a$ Eldredge, G. E., Geology of the Denver basin: Mon. U. S. Geol. Survey, vol. 27, 1896, p. 73. $b$ See pp. 87-90 for discussion of the introduction of this new term. 
of the Mesaverde formation, were defined as of Laramie age. At that time it was assumed that all of these coals must be of that age, and therefore this one formation was made to include them all. As has been explained, however, the fossils collected during the present survey indicate definitely that the more important coal-bearing series, already described as the Mesaverde formation, is to be correlated on this paleontologic evidence with the Montana group of other fields, and therefore is older than the Laramie. No distinctive fossils were obtained from the rocks that are designated as Laramie in this report, but as these strata are clearly a part of a formation next succeeding and are conformable to the Lewis shale (which is the position occupied by the described Laramie of other fields) the name has been provisionally accepted for these rocks in this field, pending further investigation upon this subject. In age this series can not be later than Laramie, as a few marine-shells were found in these beds north of Hayden, and the Tertiary formations succeeding the Laramie in this part of the United States are of fresh-water origin.

Detailed sections of the Laramie formation can rarely be obtained, because of the softness of the rocks and the consequent abundance of waste. Aside from the thick, massive sandstones, the general character of the formation is believed to be fairly represented by the sedimentary portion of the following section exposed by recent landslides in the canyon through which Elkhead Creek leaves California Park:

Section of part of the Laramie formation in Elkhead Canyon.

1. Igneous sheet

Feet. Inches.

2. Sandstone and sandy shale $\ldots \ldots \ldots$

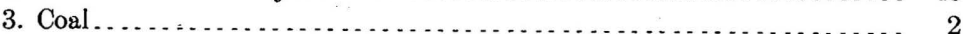

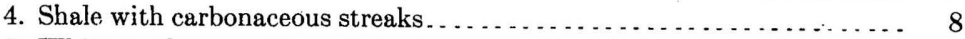

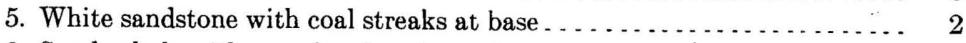

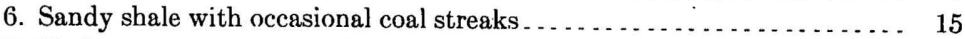

7. Shale somewhat sandy in lower portion . . . . . . . . . . . . . . 7

8. Sandstone strongly cemented with iron in upper portion . . . . . . . . . 4

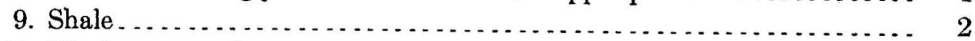

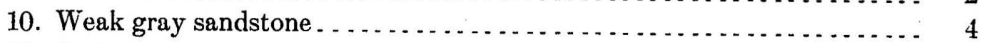

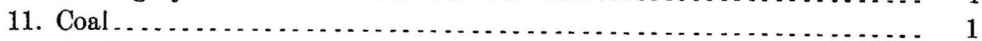

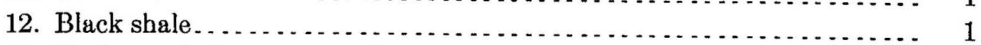

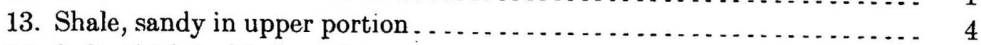

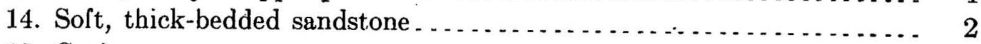

15. Coal . . . . . . . . . . . . . . . . . . . . .

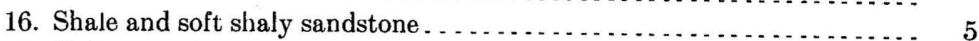

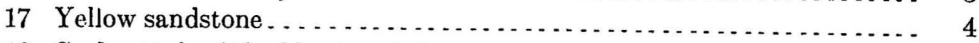

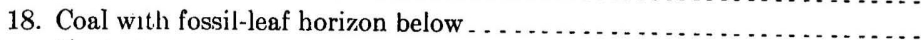

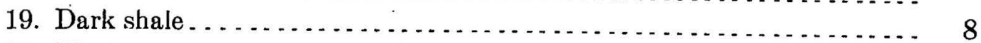

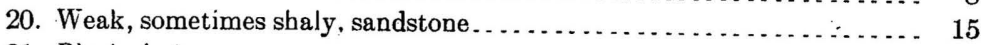

21. Black shale ... . . . . . . . . . . . . . . . . . . . .

22. Coal . . . . . . . . . . . . . . . . 10

23. Shale, sandy near middle and carbonaceous near top $\ldots \ldots \ldots \ldots$

24. Soft, yellow, thick-bedded sandstone . . . . . . . . . . . . 
Feet. Inehes.

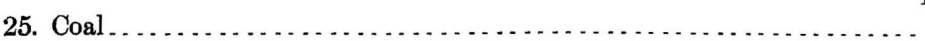

26. Shale, dark and lignitic at top ........................ 4

27. Sandstone with iron-stained concretions.................. 5

28. Carbonaceous shale ..................................... 10

29. Coal. ............................................... 10

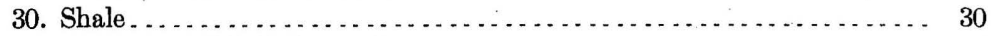

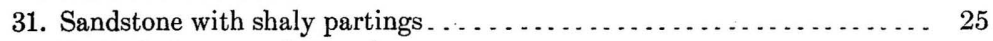

32. Dark shale, somewhat carbonaceous . . . . . . . . . . . . . . . . . 4

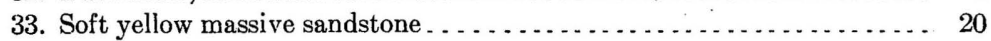

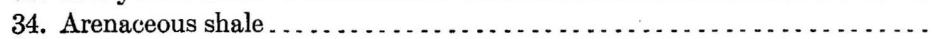

To the northwest the Laramie is undoubtedly covered by later beds of Tertiary age, as described in the King reports, but as this region was not included in the area studied and mapped no statement can be made as to the nature or disposition of the succeeding beds. With the exception of the single patch described in the next paragraph the beds of the Laramie formation were the highest examined.

\section{TERTIARY OR LATER GRAVELS.}

Between Eddy post-office and Steamboat Springs is an upland composed of smooth, rounded slopes and (where preserved from more recent stream cutting) open, well-graded valleys. This rises at its higher points to 800 or 1,000 feet above the river level. It is especially notable in that its surface is covered by a mantle of loosely consolidated bowlder and gravel beds resting unconformably upon the older rocks beneath and obscuring their structure. For the most part these gravel beds are rarely exposed so as to reveal their composition or attitude, being represented at the surface merely by bowlder débris scattered over the hill slopes. Northeast of Eddy, however, a bare scar on the mountain face exposes a clear section of at least 75 feet of these beds. In the main they are composed of a very coarse, loose conglomerate, the material of which is almost wholly granitic. Among these were noted coarse pegmatite and granite, a red feldspar and epidote granite, vein quartz pebbles, biotite-mica gneiss and schist, diorite, and a more basic hornblende rock. Interbedded with the coarser beds are thin layers of clay and beds of soft sandstone full of small flakes of biotite mica. At this particular locality the beds show a dip of $30^{\circ}$ to the northeast, but it is probable that on the whole they are approximately horizontal and that this apparent dip is marked cross-bedding.

No decision was reached as to the probable age or manner of formation of these beds. They may be correlated with the "Wasatch" beds of the Eocene (Tertiary), as shown along the western flanks of the Park Range north of the Colorado-Wyoming State line. On the other hand, they may be the deposits of an early glacial epoch. 


\section{RECENT IQNEOUS ROCKS.}

Intrusive igneous rocks of several different types cut the sedimentary beds at many points in the Yampa field. In composition these intrusive rocks appear to belong to two fairly well-defined groups or classes, possibly representing two periods of eruptive activity, both of which are later than Cretaceous. By far the more common of the two is the basalt that composes Pilot Knob, Wolf Mountain; Hooker Mountain, and many lesser peaks and ridges in this vicinity, as well as a large area in Elkhead Mountains. It is thought that the basaltic peaks southeast of Craig, the small volcanic stock near Eddy, and the larger stocks and dikes near Pinnacle and Yampa probably belong to the same period of eruptive activity, including possibly also the great basaltic mesas of Flat Top Mountains.

The sharp basaltic peaks, such as Pilot Knob and Wolf Mountain, have the appearance of huge dikes, probably representing the fissures through which the molten rock ascended. Smaller dikes of approximately vertical position radiate from the larger masses, and sills of the same material are found interbedded with the sediments in many places. These sills are the important factors in the anthracization of the coal seams. Two reasons may be given for the fact that many of the intrusives have taken the form of sills-that is, of sheets lying parallel to the bedding of sediments and coal seams: (1) The basalt when molten is a more fluid magma than that of the acidic rocks, and is therefore more readily forced into narrow crevices, and before cooling and hardening is forced to greater distances from the central stock; (2) such crevices would more easily open between the beds of a sedimentary series than across them. Where the dikes of basalt cut across the beds no extensive dislocation seems to have taken place, even in the case of so large a mass as Pilot Knob. On either flank of this peak the general westward dip of the coal-bearing rocks seems scarcely to have been interrupted.

The other type of eruptive rock is that found in Elk Mountain, Sand Mountain, Quaker Mountain, in the center of the Tow Creek anticline, and in smaller dikes at a number of other places. It is somewhat doubtful whether these should be classed with the Hahns Peak eruptive or not, although the rocks are evidently related, both as to the manner and general period of their intrusion. They are quite distinct from the basalt, being as markedly acidic in character as the basalts are basic. The acidic eruptives do not seem to be concerned in the anthracization of the coal seams, probably because in their intrusion they have usually taken the form of huge rounded or bluntly lenticular masses, and are more rarely found in thin dikes or sheets. The masses which they compose usually form the centers of uplifted areas and the sediments are tilted against these cores, indicating that the 
process by which these rocks came into place was a general doming of the strata rather than intrusion along a break in the rocks. Elk Mountain illustrates this; Hahns Peak is a most perfect example of such an intrusion, being a laccolith of rhyolite-porphyry with remnants of the uplifted sedimentary beds on its flanks; and the rocks are steeply tilted in apparently similar structure against the west flank of Sand Mountain.

\section{COAL.}

\section{COLORADO COAL FIELDS.}

\section{AREA.}

The total area of the coal fields of the State of Colorado has been estimated as 18,100 square miles, ${ }^{a}$ of which area 50 per cent is estimated as workable. The State ranks fifth in the area of its coal fields and eighth in the tonnage of its production, according to the reports for the year $1904, b$ the total production in Colorado in that year amounting to $6,658,355$ short tons.

\section{DISTRIBUTION.}

As shown on fig. 2, the coal fields of Colorado lie on both flanks of the Rocky Mountain Range. The South Platte River field, the Raton field, and the Canyon field lie along the eastern edge of the mountain ranges, the Middle Park and North Park fields lie within the great mountain area, and the Yampa, Grand River, and Durango-Gallup fields lie on the western flanks of the mountains. With this latter group should be classed the Carbon-Hanna, Rawlins, and Rock Springs fields in southern Wyoming.

\section{CHARACTER.}

The general character of the Cretaceous coals of the Western States is subbituminous, but owing to conditions of mountain building and volcanic action they have been metamorphosed locally into the higher grades of bituminous coal and anthracite. This form of metamorphism is frequently designated "regional," as contrasted with "local." By regional metamorphism is meant those changes in rocks that are wrought by the forces of heat and pressure accompanying deep burial and mountain-building upheavals. Local metamorphism includes those changes effected by igneous intrusion, which are largely the result of the heat of the molten rock, but also includes the chemical changes brought about by the hot gases and solutions

a Hayes, C. W., The coal fields of the United States: Twenty-second Ann. Rept. U. S. Geol. Survey, pt. 3,1900-1901, p. 13 .

$b$ Mineral Resourees of the United States for 1904, U. S. Geol. Survey, 1905, p. 459.

Bull. 297-06-3 
which accompany such processes. As these names indicate, the former is comparatively uniform and far reaching in its effects, while the latter is restricted to the immediate vicinity of the eruptive masses which cause the change. The anthracite coals of Pennsylvania are

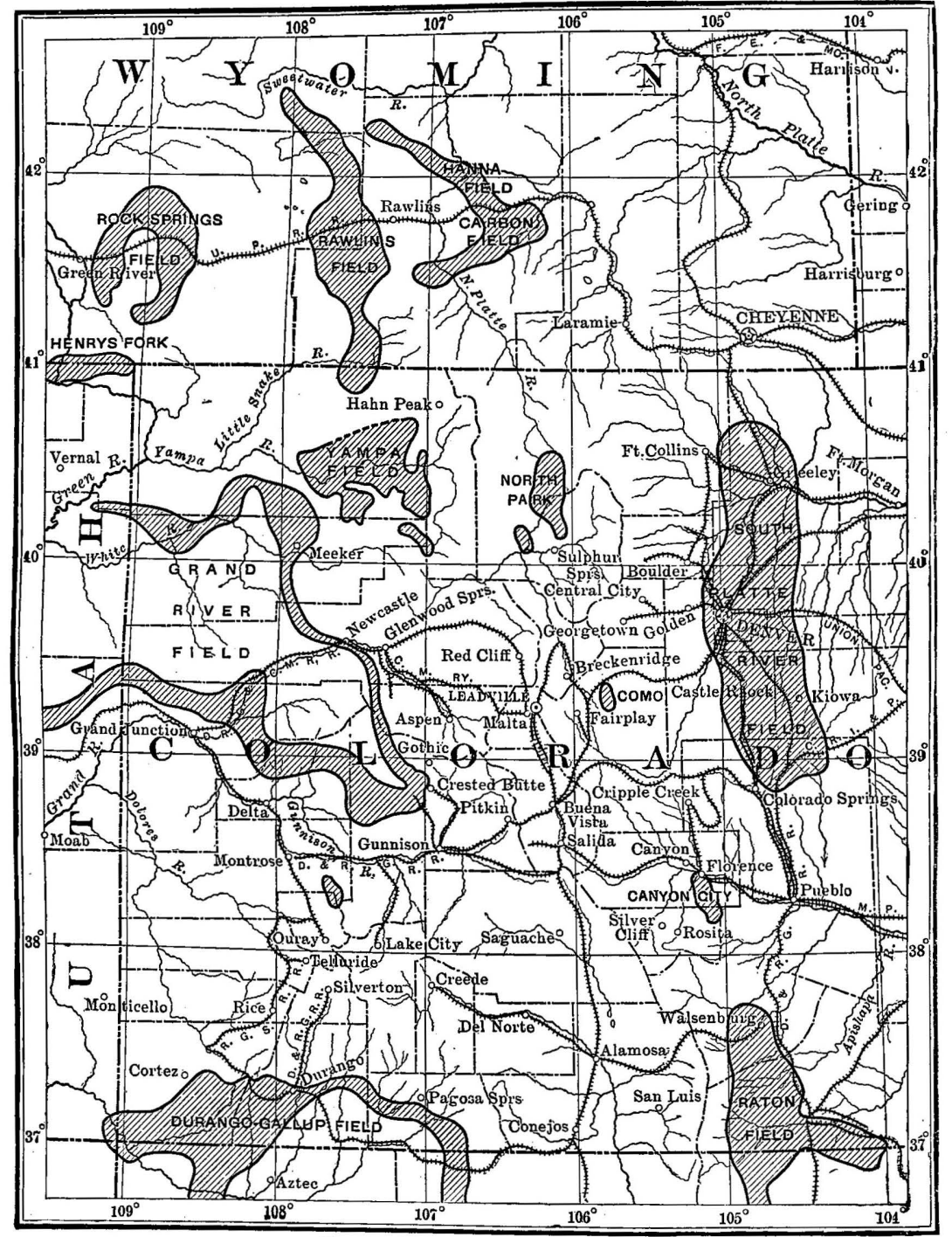

FIG. 2.-Index map of Colorado coal fields.

the product of regional metamorphism of original or normal bituminous coals just as the bituminous coals of the Rocky Mountains are the product of regional metamorphism of original subbituminous coals, but the anthracites of the Rocky Mountains are the product of local metamorphism. 
In general it may be said that in close proximity to the mountains the coal is changed to bituminous and at some distance it retains its original subbituminous character. East of the Rocky Mountains the subbituminous coals in general occur in the central and eastern parts of the fields, while bituminous varieties are found along the flanks of the ranges. North and south of the region as a whole a similar change can be noted, from the high-grade coals near the mountain masses to subbituminous in Wyoming and New Mexico. On the west, also, the low-grade coals are found in fields farther removed from the great mountain masses which constitute the core of the Rocky and San Juan mountain ranges.

On account of this metamorphism in the vicinity of the mountain masses, and also on account of its variability from place to place, the State of Colorado contains representatives of almost all grades of coal that are known. Anthracite is found only in limited areas, and at present is mined only at Crested Butte, in Gunnison County, where approximately 50,000 short tons were produced in $1904 .{ }^{a}$

Bituminous coal is much more common, occurring in the Raton, Durango, Grand River, and Yampa fields in large quantity, and probably in other fields to some extent. Subbituminous coal occurs in almost all of the fields of the State.

There are a great number of classes of bituminous coals, but perhaps the most important is the class of coking coals. These are indispensable in the modern practice of iron making, and consequently they are in great demand. So far as known at the present time the Raton, Durango, and Grand River fields are the only ones containing good coking coal. From time to time reports are current regarding the discovery of coking coals in other fields, but the quantity has always proved too small to be of commercial value, or the quality such that the product could not be marketed. Las Animas, Gunnison, Pitkin, and La Plata counties now produce coal that is utilized for coking, and coal from Garfield County has been coked in the past. Of the $6,600,000$ tons of coal produced in Colorado in 1904, about $1,100,000$ tons were made into coke, this product being largely from the Raton field in Las Animas County. ${ }^{b}$

The general principles outlined above apply fully to the conditions found in the Yampa field. Anthracite occurs in regions in which extensive eruptive activity has taken place since the time in which the coals were formed. The bituminous beds lie within the folded and broken strata of the Colorado Plateau, where these beds now lie tilted against the old uplifted core of the Rocky Mountains. The stresses that produced the folding were transmitted from the center of uplift through the resistant sandstone members that form a part of this

$a$ Mineral Resources of the United States for 1904, U. S. Geol. Survey, 1905, p. 417. $b$ Ibid., p. 462. 
bituminous coal-bearing series. The coal seams within these beds were at that time buried under the tremendous weight of many thousands of feet of sediments which have now. been eroded wherever the coals are exposed. Thus, confined between beds of massive and resistent sandstone, buried under the weight of thousands of feet of sediments, these coal seams were compressed vertically and lateraliy into folds and broken by faults. The forces that accomplished this were transmitted through the beds in which the coals were container. The weaker shaly beds above and below conformed themselves to the structures determined in the sandstone series. The Laramie beds not only supported a comparatively lesser weight of overlying sediments, but by reason of their weaker constituent members accommodated themselves to shifting positions by minor internal crumpling and breaking, and their coal seams were not so unusually compressed.

\section{MARKETS.}

The eastern Colorado coal fields have the advantage of accessibility to the markets of the open prairie States. For the present the Denver and Pueblo markets are the main objective points from most of the Colorado fields in the northern half of the State. The western fields are all at more or less disadvantage on account of the circuitous rout's and heavy grades that must be traversed to transport their product to the East. With the development of additional transportation facilities it is thought that markets west of Colorado, even to the Pacific coast, will become important factors in the development of the Colorado fields; however, the existence of good coal fields in Utah and Wyoming must not be overlooked.

\section{YAMPA FIELD.}

For convenience in describing the Yampa field, it has been divided into four main structural divisions as follows: (1) Twentymile basin, which includes the extreme southeast point of the major syncline, and is bounded on the northwest by the Tow Creek anticline (p.14); (2) Williams Fork Mountains, which includes the southern rim of the main basin west of the Tow Creek anticline and Twentymile Park and also the outcrops in Yampa Valley in the vicinity of Craig; (3) Wolf Creek district and Anthracite Range, including the coal beds expose' $d$ along the eastern rim of the main basin from Twentymile Park as far north as the coals have been traced, and (4) Elkhead and Quaker Mountain district, including the subbituminous coals of the Laranie formation, which lie in the structural center of the main basin of the Yampa field. 
TWENTYMILE BASIN.

\section{STRUCTURE AND SUBDIVISIONS。}

The southeastern end of the main field is a complete structural basin. Although this basin is far from being symmetrical, the strata have a general dip from all sides toward the center, which is represented by the rolling prairie land of Twentymile Park. This structural basin includes the coal districts on Oak, Trout, Middle, and Fish creeks, the coals exposed about the rim of Twentymile Park, and also a small area north of Twentymile Park extending across Yampa River about 2 miles west of Pool post-office.

The lowermost strata exposed are those about the outer rim of the basin, and these dip beneath successively higher and higher beds toward the cenuer. The most complete stratigraphic section of this part of the field is therefore represented by the beds that underlie Twentymile Park. The topmost of these beds is the soft dark calcareous Lewis shale, which forms the surface of most of this park. The dark shale itself rarely shows in outcrop except in the banks of streams or in gullies on steep slopes. Its easily eroded surface is usually covered by a mantle of soil and vegetation. However, a large part of the surface is strewn with irregular gray to bluish fragments of limestone, showing rounded edges and frequently weathering to brilliant red and yellow on their faces, or filled with seams of pure white calcite. Some of these show. cone-in-cone structure. These fragments are known to be derived from harder layers of the Lewis shale.

Between the topmost shale and the lowermost sandstone exposed along the rim of the park there is contained the complete coal-bearing series of the Yampa field, exclusive of the Laramie beds described in a later chapter.

For the purpose of describing the various mines and outcrops, each of the four main structural divisions is further subdivided into districts, more especially with reference to economic considerations of distribution rather than to geographic location or structural situation. Each creek valley usually forms a distinct district or commercial unit, for the developments in a single valley are commonly subject to similar conditions of accessibility and convenience to market, and these conditions are usually different from those of adjacent valleys in the same structural district. In this way the Twentymile basin will be considered as comprising the following districts:

1. Twentymile Park district.

2. Dunkley Canyon district.

3. Oak Creek district.

4. Trout Creek Canyon district.

5. Eddy district.

6. Pool district. 


\section{TWENTYMILE PARK DISTRICT.}

This district is intended to include coal exposures or such openings as may be made in or about the open prairie lands of Twentymile Park. The general features of this park have already been described under the heading "Structure." It will suffice to repeat that the open prairie land represents the uppermost beds of the Mesaverde formation and the beds of the soft Lewis shale, and that below this surface should be found the whole coal-bearing series with the exception of the Laramie beds. The part of the Mesaverde formation lying above the Twentymile sandstone member constitutes the upper coal group. It is composed of a variable thickness, probably averaging 300 or 400 feet, of light-colored sandy and shaly strata with coal beds. It is defined above by the black shale of the Lewis shale, and below by the massive Twentymile sandstone member. As the rocks that form the northwest side of the Twentymile basin plunge under at a much steeper angle than do the gently dipping beds on the southeast side, it is probable that the bottom of the structural basin lies near the western side of Twentymile Park, and that the upper coal group there sinks to its greatest depth below the overlying shale.

On the southeast side of the park the seams of the upper coal group lying, as this group normally does, on the back of the dip slopes of the massive Twentymile sandstone member show in many places in natural outcrop, some of which are indicated on the map (Pl. I, pocket). A measurement at the mouth of Foidel Canyon of an exposed coal seam and the strata lying between it and the Twentymile sandstone, all dipping northwardly at an angle of $17^{\circ}$, gives the following result calculated to stratigraphic thicknesses:

\section{Section at mouth of Foidel Canyon.}

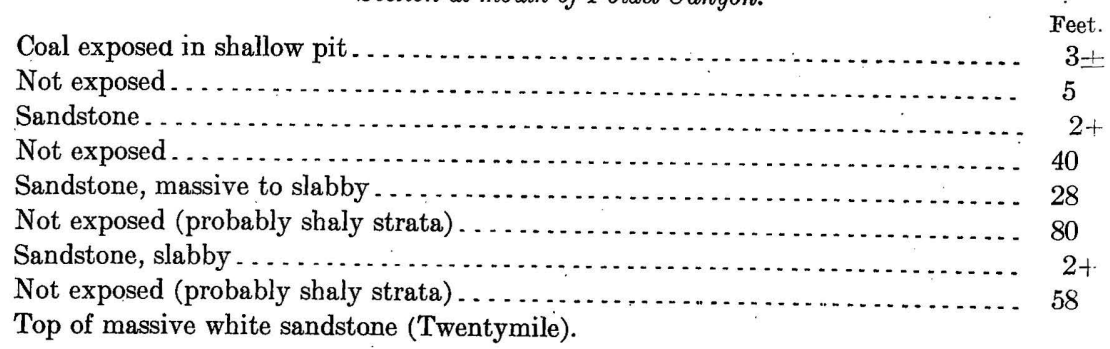

The coal seam shown at the top of the above section was exposed in natural outcrop and appeared to be $2 \frac{1}{2}$ to 3 feet thick. Other exposures of coal of similar character and at approximately the same horizon appear northeast and southwest of this point. In these natural outcrops the coal seemed to have a thickness of 3 to 4 feet; but it 
is thought that these estimates are likely to fall below the actual thickness of the seams, as is known to be the case in other localities where coal lies at the surface among strata broken down by surface weathering.

The representation of the outcrop of the upper coal group on the map is only approximate. These coals lie above the massive ledges of the Twentymile sandstone and are themselves covered by beds of soft and easily eroded shale. As both the upper coals and the overlying shale occupy in many parts of the field an approximately horizontal position, slight undulations of the strata may bring these coals to outcrop almost anywhere in the shale valleys, and, on the other hand, may also carry the same coal seams to a considerable depth under the shale cover without necessarily showing any surface indication of this structure in the sagebrush prairie of the valley lands. This is true of the upper coal group throughout the field, with the exception of the few districts in which these rocks are tilted at such high angles as to make their outcrop a fairly definite line. The inferior quality of some of these coals that have been prospected is probably due to lack of sufficient cover to afford protection from atmospheric agencies. The probability is, however, that under large areas this coal group is sufficiently buried to have preserved the coal from such deterioration. Naturally the seams more deeply buried are not the ones most readily discovered in prospecting.

The coals of the middle and lower groups in all probability underlie the upper coals of Twentymile Park in normal succession. They would thus be encountered by sinking shafts or drilling test holes to sufficient depth. Perhaps the best estimate of this depth without drilling would be obtained from a careful measurement of the stratigraphic column at some point as near as possible to the locality in question. For this purpose the strata must be traced to where they emerge in order that their eroded edges may be measured. The Twentymile sandstone will often furnish a convenient datum plane to which these measurements may be tied. Below this sandstone stratigraphic thicknesses may be counted on as fairly constant over limited areas, but the estimate of the thickness of the Lewis shale overlying is a much more uncertain problem. The coal seams themselves are not strictly continuous, but they persist as groups of fairly definite horizons. As a general statement it may be said that the middle coals would probably be encountered 600 feet and more below the Twentymile sandstone and the lower coals 600 feet or more below the base of the middle group. 


\section{DUNKLEY CANYON DISTRICT.}

As has been stated, Twentymile Park is bounded on the west by ridges of steeply upturner strata. Fish Creek cuts through this wall a little north of Dunkley post-office in a sharp canyon in which a section of nearly the whole Mesaverde formation is well exposed in a short distance (see Pl. VIII). The rocks dip to the east-northeast at angles ranging from $50^{\circ}$ to $63^{\circ}$. Williams Park above the canyon is eroded on the soft Mancos shale that underlies the Mesaverde formation, while Twentymile Park, at the other end of the canyon, is opened on the soft Lewis shale above. As the canyon is cut almost directly across the strike of the immediate coal-bearing beds, it affords an excellent opportunity for a study of the succession of beds. Old coal openings near water level show that seams of both middle and lower groups have been mined, probably for local use. The following measurements, calculated to stratigraphic thicknesses, were obtained at this place:

\section{Section of coal-bearing strata in Dunkley Canyon.}

Twentymile sandstone: Massive white ledges at the top of the series; no upper coals were noted at this point.

Interval of less resistant beds, probably mostly shaly strata, with here and there thin sandstones.... . .................................. 900

Coal, one large and several small seams (see next table)............... $12+$

Shaly beds . . . . . . . . .

Sandstone, massive . . . . . . . . . . . .

Shaly beds. . . . . .

Sandstone, massive (Trout Creek member) ............................ 18

Shale, forming marked valleys . . . . . . . . . . . . . . . . . . . . . . . . . . . . 800

Sandstones, massive. Two beds, between which is a 6 -fort coal seam belonging to the lower group . . . . . . . . . . . .

Total (not including upper coal group nor lower barren sandstones) $\ldots \ldots .1,175$

Measurement at 12-foot seam of middle group in Dunkley Canyon.

Clay . . . . F . Feet.

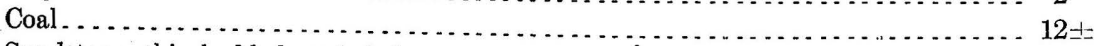

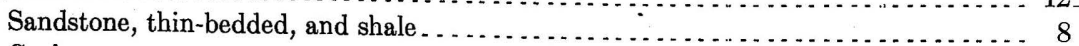

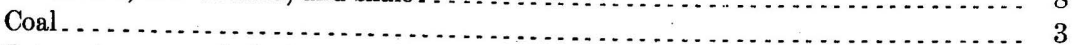

Interval not recorded, shale and thin sandstone beds $\ldots \ldots \ldots \ldots \ldots \ldots \ldots \ldots \ldots$ (?)

Coal . . . . . . . . . . . . . . .

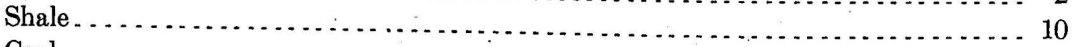

Coal . . . . .

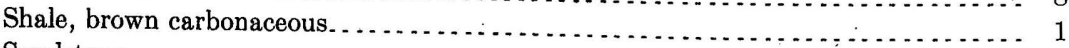

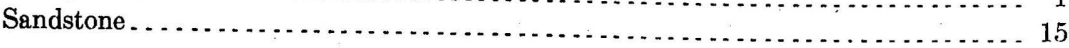

The principal coal mine of the distriet is opened on the south side of the valley in the 12-foot seam belonging to the middle coal group. 


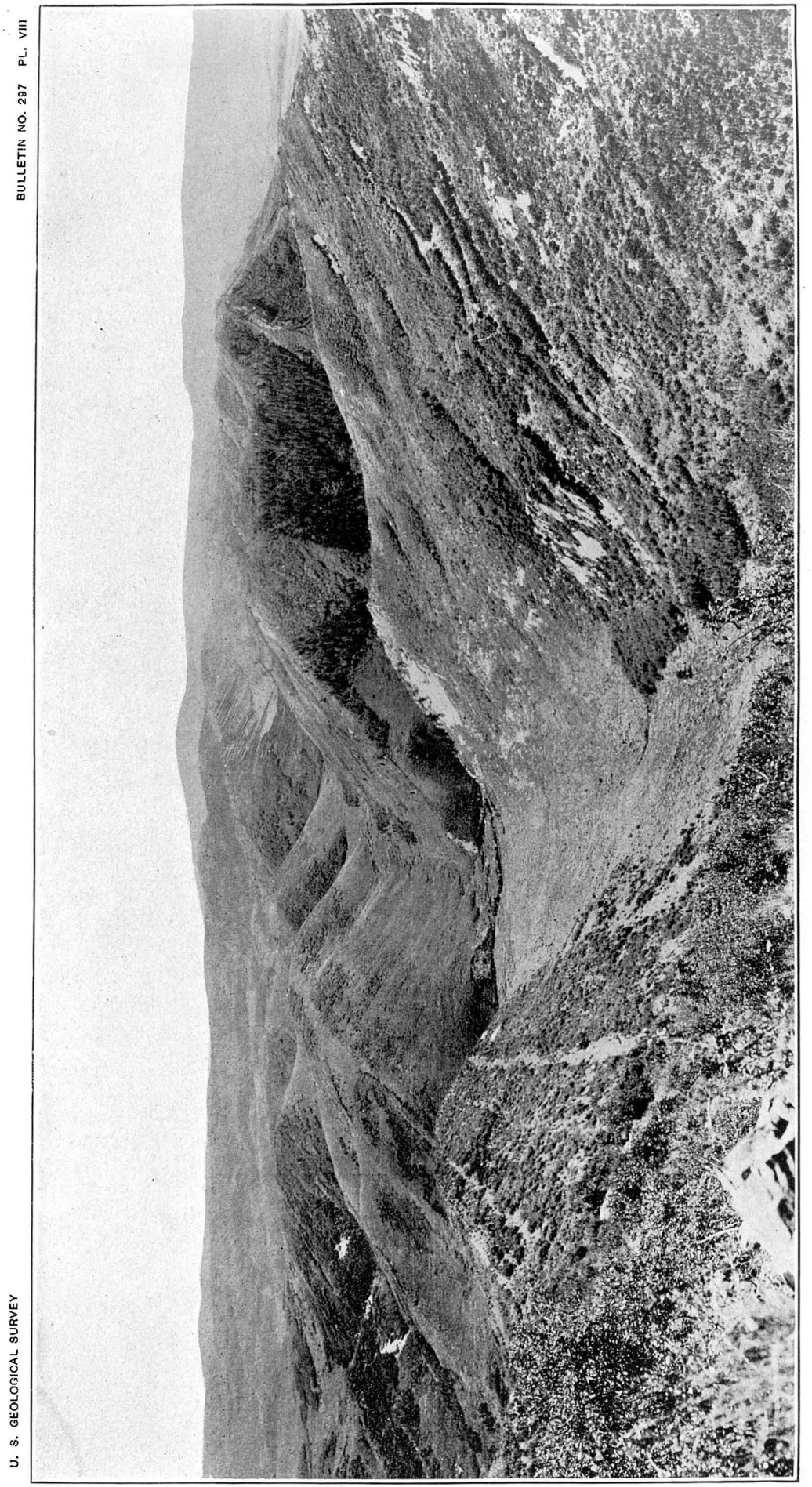

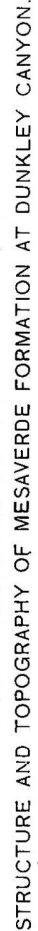



The 6-foot seam of the lower group has been mined on the north side of the valley, but the roof being of shale much timbering was required and the mine is in bad condition. It is not being worked at present.

\section{OAK CREEK DISTRICT:}

Occurrence.-Oak Creek heads under the north end of the Flat Top Mountains, west of the village of Yampa. From its head it flows in a general northeasterly direction, cutting across the southeastern point of the coal field and joining Yampa River a few miles south of Steamboat Springs. Coal seams outcrop along its middle course for a distance of about 10 miles. In this part of its course the creek bed practically outlines the extreme southeastern limit of the coal field. Coal beds occur in the high bluff north of Pinnacle post-office, and, although not examined, they probably are continuous along the bluff on the north side of the creek to the vicinity of Pallas post-office, from which point the creek and the coal outcrops take a more northerly course. This valley, by reason of its accessibility to the markets of Yampa and Steamboat Springs, has received much attention as a portion of the Yampa field and has been perhaps as extensively developed as any other single district of the field. No mine, however, has been opened to a distance of more than a few hundred feet. Of the openings the more important are the James mine, the Shuster mine, and the mine of the Steamboat Springs Electric Company. The coals in all of these are thought to be of the lower group.

James mine.-The openings known as the James mine are situated on a small tributary valley of Oak Creek, about 2 miles west of Pallas, and by the side of the road that runs from Pallas post-office by way of Foidel Canyon to Dunkley post-office. Openings have been made on three seams, separated by stratigraphic intervals of about 35 feet each. The beds dip about $10^{\circ} \mathrm{NW}$. The principal mine is on the uppermost of these three. An entry has been driven in on the coal for some distance and considerable coal has been mined for local use. The mine was not in operation at the time it was visited and a complete section could not be obtained. The exposed part of the bed is as follows:

Section of upper coal bed at James mine.

Shale, dark ............... Feet. Inchẹs.

Coal

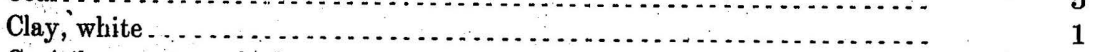

Coal (base not reached) $\ldots \ldots \ldots \ldots \ldots \ldots \ldots+7+$ 
The next or middle coal seam was not accessible and consequently was not measured. An incomplete section of the lower seam, as shown in the principal opening at this point, is as follows:

Section of lower coal seam at James mine.

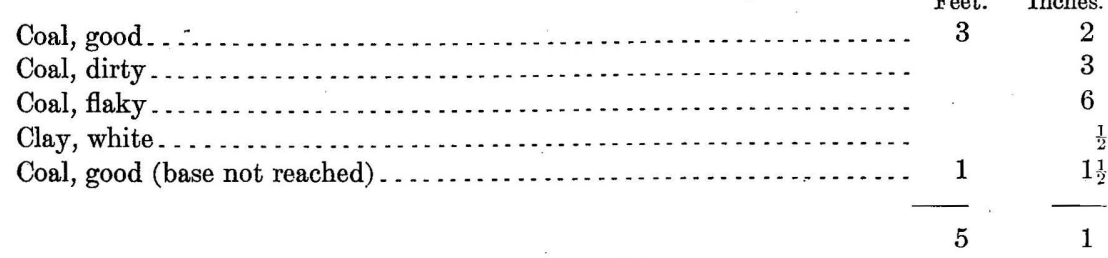

Shuster mine.-The entry known as the Shuster mine is on the west side of Oak Creek, about 2 miles north of Pallas post-office. An entry has been driven in on the coal bed for several hundred feet and a large amount of coal has been taken out for local use. At the time of visit the coal was being hauled from this point to Steamboat Springs for use in the Electric Light Company's plant. The mine is on the lowest seam exposed, which is regarded as being the same as the thickest bed at the James mine. There are indications of at least four other seams on the hill slope above, all of which are exposed by prospect holes within a mile of the Shuster mine. The section of the coal bed in this mine is as follows:

Section of coal bed in Shuster mine.

Roof, sandy shale.

Feet. Inches.

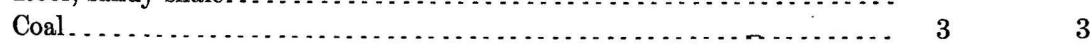

Shale, carbonaceous.................................... 1

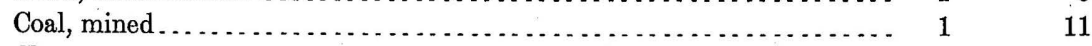

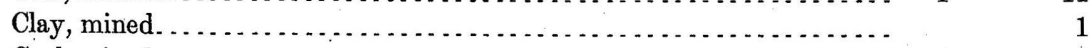

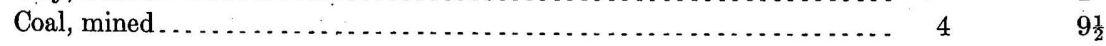

$11 \quad 6 \frac{1}{2}$

A less detailed section showing all the coal seams recorded in this locality is as follows:

General section of coal beds near Shuster mine.

Coal Feet. Inches.

Interval 5

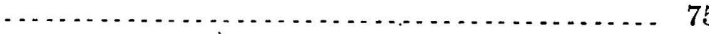

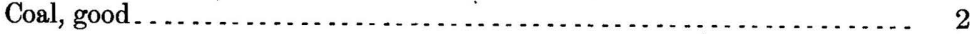

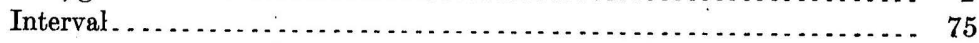

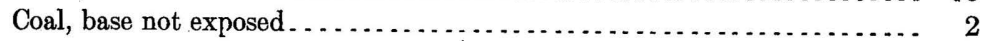

Interval . . . . . . . . . . . . . . . . . . . .

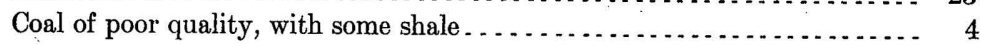

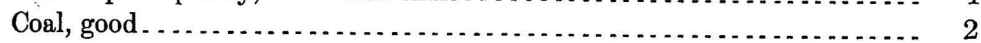

Interval . . . . . . . . . .

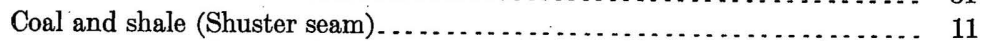

Sandstone, massive or thick-bedded.......................... 22

Shale and thin sandstone .................................. 22 


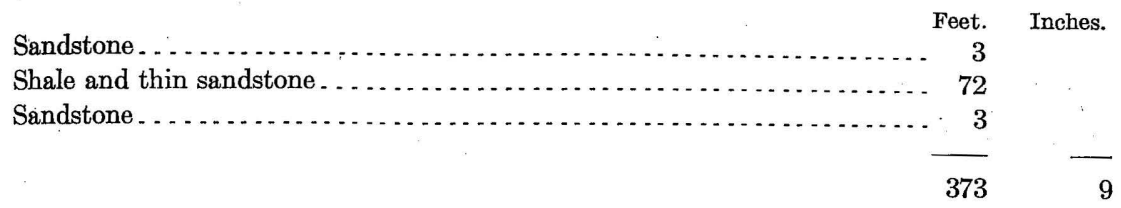

The Shuster seam dips about $20^{\circ} \mathrm{NW}$. From the structure of the country it is known that the dip rapidly flattens to the northwest. A sample was taken at this mine for chemical analysis. It was obtained by making a cut across the seam where freshly exposed in the mine, saving only the good coal, as indicated in the two lower benches of the section above, and rejecting the clay seam. This large sample was pulverized, quartered to a convenient size, and sealed at the mine for transmittal to the chemical laboratory. (Analysis A, p. 84.)

It is not to be expected that the individual coal seams retain their characteristics throughout the length of the district, although it is not impossible that this will be found to be so in the case of some one of the larger seams. For this reason any present correlation of the Shuster seam with the larger seams of the James or Electric Light Company's properties is very uncertain. From the Shuster mine northward the outcrop of this group of coals as a whole is readily traceable along the valley of Oak Creek to a point several miles north of the property next described.

Steamboat Springs Electric Company mine.-At the point where Oak Creek turns to the northeast and leaves the Yampa-Eddy road developments have been made on several seams exposed on both sides of the creek. A measurement was made at this point in the bluff on the north side of the creek. The beds are dipping a little north of west at an angle of $45^{\circ}$. Calculated to stratigraphic thicknesses the result is as follows:

Section of lower coals at Steamboat Springs Electric Company mine, on Oak Creek.

\begin{tabular}{|c|c|}
\hline Sandstone, massive & $\begin{array}{c}\text { Feet. } \\
35\end{array}$ \\
\hline Covered (probably shaly beds) $\ldots \ldots \ldots \ldots \ldots \ldots \ldots \ldots$ & 70 \\
\hline Coal, old working $\ldots \ldots \ldots \ldots \ldots \ldots$ & $6+$ \\
\hline ndstone. . . . . . . . . . . . . & 30 \\
\hline Shale . . . . . . . . . . . . . . . . & 10 \\
\hline ................ & \\
\hline Interval (probably shaly) $\ldots \ldots \ldots \ldots \ldots \ldots \ldots \ldots$ & 25 \\
\hline Coal. .. & $2 \pm$ \\
\hline Shale $\ldots \ldots \ldots$ & 50 \\
\hline Coal (equivalent to seam of old mine on south side of creek) $\ldots \ldots \ldots \ldots$ & $(?)$ \\
\hline Interval (probably shaly beds) $\ldots \ldots \ldots \ldots \ldots \ldots$ & 60 \\
\hline 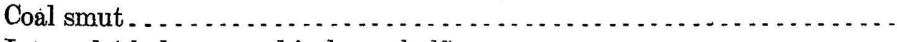 & $(?)$ \\
\hline Interval (shale exposed in lower half) $\ldots \ldots \ldots \ldots$ & 40 \\
\hline Coal (old mine), thought to be equivalent to Shuster seam . . . . . . . . . & $6+$ \\
\hline
\end{tabular}

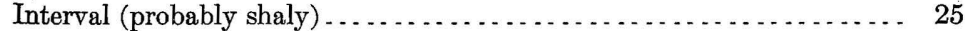

Coal ........................................... $2 \pm$

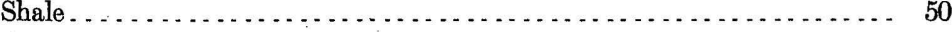

Coal (equivalent to seam of old mine on south side of creek) .......... (?)

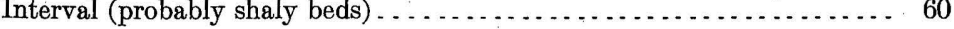

Coal smut................................................ (?)

Coal (old mine), thought to be equivalent to Shuster seam ........... $6+$

Sandstone, massive . . . . . . . . . . 
As shown above, coal shows at six horizons within a thickness of 230 feet of strata. The coal in these seams is said to be much crushed.

Miscellaneous prospects.--Southeast of Oak Creek (secs. 12 and 13, T. 3, R. 86) several coal seams were found on the edge of a high mesa at the top of a conspicuous bare scar visible from the stage road. The following is a portion of a stratigraphic section measured at this point:

Seam of the lower coal group as exposed on high mesa south of Oak Creek.

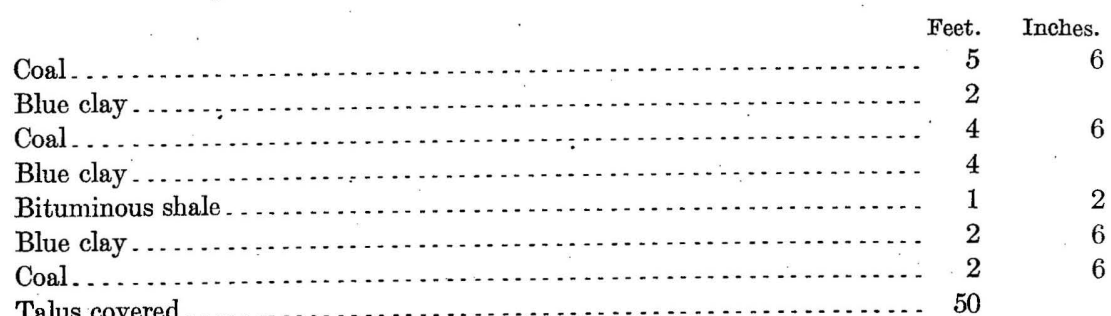

Judging from this measurement it seems likely that a number of the thicker seams of the lower group are to be found in this part of the field. The area of the coal strata is, however, of limited extent, being cut off from the main field by the canyon valley of Oak Creek. The coals are not so accessible as the seams along the lower valley of Oak Creek, lying as they do at considerable elevation above water level.

Prospect pits have been opened at many points along Oak Creek below the Shuster mine, both along the roadside near creek level and on the hillsides above the road. All of the seams near the road are thought to be of the lower group and similar to those already described.

Beyond the mines of the Steamboat Springs Electric Company the lower coal group was traced along a nearly due north course for about 3 miles. Its extension in this direction is readily recognized by the outcrops of the coal seams and also by prominent hogback ridges until within a short distance of Eddy post-office, where all trace of the group was lost, as is explained in the description of the Eddy district (p. 47). Along the top of the high bluff on the west side of the creek are prospects on seams whose position indicates that they belong to the middle group of coals. The few openings on these upper seams that were visited did not seem to indicate such valuable seams as those of the lower group in this vicinity, and are not so readily accessible. This group was readily tracecble to -where it joins with the seams of the same group of the Eddy district, as explained later (p. 50) and as indicated on Pl. I (pocket). 


\section{TROUT CREEK CANYON DISTRICT.}

Trout Creek flows in a narrow and steep-walled canyon across the upturned edges of the massive sandstone beds which underlie or embrace the lower group of coals. (See general section, p. 23.) This canyon begins at a point about 2 miles northwest of Pinnacle post-office and extends to Male's ranch, at the mouth of Egeria Gulch, a little over 5 miles above Eddy post-office. As has been stated, coal seams are known to outcrop in the face of the high bluff north of Pinnacle post-office, and these are almost certainly of the lower group. The high plateau east and west of Trout Creek Canyon was not visited, and the position of the coal groups there mapped is inferred from the general structure. As the sandstone beds follow down Trout Creek in approximately horizontal position from near Pinnacle post-office, it is thought that the coal beds would be found outcropping along the summits of the ridges adjacent to the canyon. About 1 mile above Male's ranch, however, the beds suddenly dip to the northeast (see p. 15), and the coal seams of the lower and middle groups are brought down and pass beneath the level of the stream. Several openings have been made on these seams as they approach water level.

About 1 mile above the mouth of the canyon a 40-foot entry on the west side of the creek has been opened on a seam of about $6 \frac{1}{2}$ feet of coal. This coal is without constant character near the entrance, containing lenses of sandstone up to 8 inches in thickness, which vary markedly from point to point. At the breast of the drift the following measurement was made:

Measurement at breast of upper opening on Trout Creek Canyon.

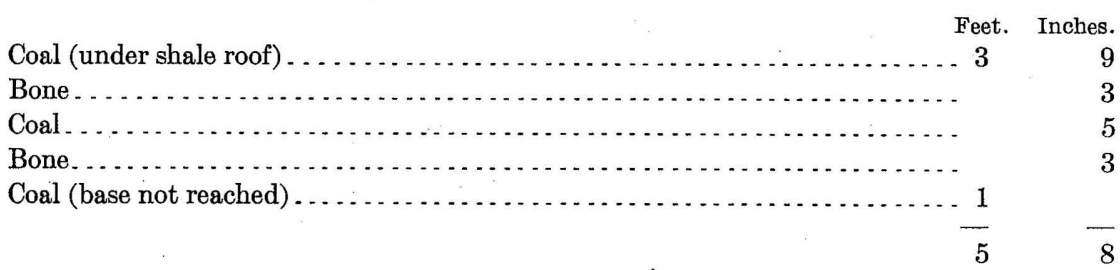

Although this coal had been exposed for some time and appeared to be somewhat weathered, a sample, including all the good coal in the section detailed above, was taken for analysis (analysis B. p. 84).

About three-quarters of a mile downstream from the opening just described, also on the west side of the creek, is an entry driven in about 100 feet on a seam also belonging to the lower group and apparently about 200 feet higher stratigraphically than the seam last named. It dips due northeast at an angle of $32^{\circ}$. The following measurements were taken in the entry: 
Section measured at entry one-fourth mile above mouth of Trout Canyon.

Feet. Inches.

Sandstone, slabby

Coal $\ldots \ldots \ldots$
Clay, blue $\ldots \ldots \ldots \ldots \ldots \ldots$

Coal . . . . . . . . . .

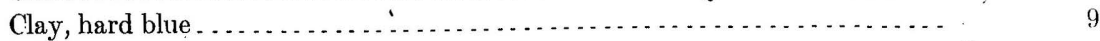

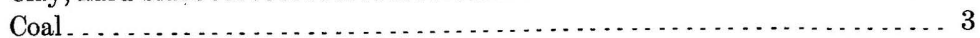

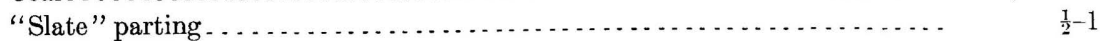

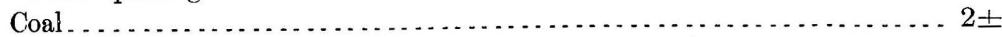

On the east side of the canyon, nearly opposite the tunnel, is an exposure of at least 2 feet of coal, but the entire thickness of the seam could not be ascertained. Stratigraphically it is intermediate between the two seams, which have been opened on the west side of the canyon.

All the seams exposed in the canyon of Trout Creek are included in the group of massive sandstones, and do not therefore represent the uppermost seams of the lower group, which are characteristically associated with weak sandstones and shales (see general section, $p$. 23). These latter should come to the surface beneath Egeria Gulch.

On the northeast side of this gulch are found the coals of the middle group, the strata containing these being continuous from the high bluff west of Oak Creek on the Yampa-Eddy road.

On the east bank of Trout Creek, opposite Mr. Male's house, several seams of coal show in an irrigating ditch. On one of these an entry has been opened near Mr. Male's stable. The drift is in about 30 feet and is well timbered, the latter being necessary on account of a poor roof. The following measurement was made:

Measurement made at Male mine, Trout Creek.

Clay - Feet.

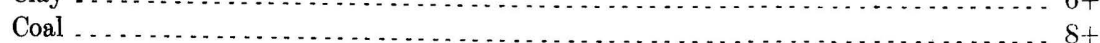

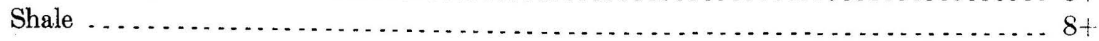

The total coal seam was not exposed in the mine, where but 5 feet of coal had been taken out, 3 feet being left for roof. A few inches at the base of the seam are shaly.

To the east and north of the Male mine and the mouth of Trout Creek Canyon the middle coal group is probably continuous, joinin with the corresponding group in the Oak Creek district, and thence, as has been stated, extending northward to meet the coals of the Eddy district on lower Trout Creek. It was not possible to trace the exact location of the outcrops of these middle coals, but as they are known to exist near the crest of the ridge between Oak and Trout creeks they have been mapped along this divide. From the Male mine westward the outcrops of the middle coals extend approximately parallel to the old county road leading toward Dunkley. The seams outcrop in the canyon of Middle Creek, where the road crosses this stream, and a 
single exposure was found near the same road in Foidel Canyon still farther west. In the southern portion of Foidel Canyon, known as Eckman Park, the mapping of the outcrop of the middle coal group is a rather indefinite problem, for this park is an open valley eroded on the weaker shaly strata that occupy the interval between the Twentymile and Trout Creek sandstones, and that also contain the seams of the middle group. Difficulty will be found in an attempt to determine what seams still remain in this district and what have been eroded, and it is thought likely that they may be found outcropping almost anywhere in this prairie land. From Foidel Canyon the coals extend continuously around the southwestern end of Twentymile Park to where they are so admirably exposed in Dunkley Canyon (see p. 40).

\section{EDDY DISTRICT.}

General description.-Eddy post-office is situated near Trout Creek, about 8 miles above its junction with Yampa River. It lies on the eastern border of the coal field, immediately surrounded by the outcropping strata of all three coal groups. The geologic structure of the district surrounding Eddy, while simple and readily understood in a part of the area, is extremely irregular at other places. 'The recognized presence of a number of faults of somewhat uncertain magnitude in the rocks exposed, together with the difficulty experienced in tracing with certainty the outcrops of the various coal groups and associated sandstones, leads to the assumption that the district has been subjected to considerable faulting. Where faults were actually observed or were inferred with some certainty, they are indicated as such upon the map. They are, however, for the most part so obscure that no attempt has been made to place a definite interpretation on the details of structure observed, and the lower coal group at this point has been mapped in discontinuous patches for want of more definite information. The outcrop of the middle coal group was traced with less difficulty. Both groups carry a number of large coal seams in this district, and many entries and prospects have been opened upon the seams.

Lower group.-The lower sandstones of the Mesaverde formation can be readily traced for about 3 miles in an almost due north direction from the mine of the Steamboat Springs Electric Light Company on Oak Creek. Beyond this the hogbacks and ledges suddenly disappear, their extension being apparently occupied by a broad open valley 1 mile due southeast of Eddy post-office. Prospects on coal seams were found a mile or more farther north, but the strata containing them are of various attitudes of dip and strike. From the rather meager evidence at hand it seems probable that a fault develops near Mr. Whetstone's house and extends to the southeast up the open valley that lies in that direction and that the coal-bearing strata north of this fault have been dropped with reference to the rest of the field. 
Such a fault would explain the abrupt ending of the outcrop of the lower groups of coals on the road from Eddy to lower Oak Creek and would explain the presence of coal beds belonging to the lower group in the hill east of Mr. Whetstone's house on the north side of the county road. At one time efforts were made to develop this coal for the Steamboat Springs market, but the seams were irregular in thickness, and the quality of the coal is not the same as that on Oak Creek, from which at present Steamboat Springs draws its supply. After considerable work the mines east of Eddy were abandoned.

The coal beds showing in the hills mentioned above are continuous with the coal showing along Trout Creek below Mr. Whetstone's house. These coal seams measure from 2 to 4 feet in natural outcrop in the creek bank and near water level. On the north side of the creek and near the base of the volcanic stock there is a seam showing at least 2 feet of coal in outcrop.

These coal beds continue to the 'west, their most important development being at the Jones mine, on the north side of the creek and about $1 \frac{1}{4}$ miles below Eddy. This mine is opened near water level, where the rocks are nearly horizontal, the dip being to the southeast and very light. When visited, the entry was so badly caved that the measurements were taken at the outcrop. The following section was recorded:

Section of coal bed at Jones mine, Eddy.

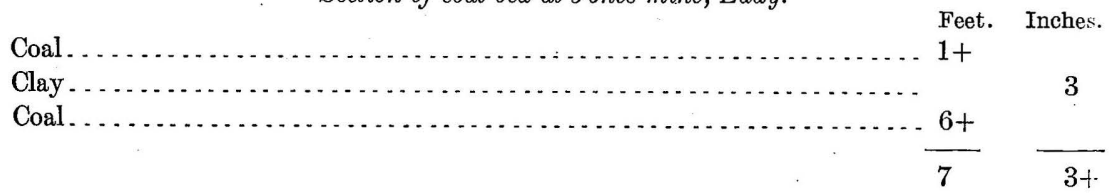

No sample for analysis was taken on account of the condition of the mine.

West of the Jones mine the position and extension of the lower coal group are somewhat uncertain. The rocks of the region show evidence of considerable faulting, and it seems possible that the block of strati containing the lower coal group east of Mr. Whetstone's, just described, may be faulted off toward the west and have no direct connection with the coal beds in the principal part of the field.

Lower down along the course of Trout Creek, near the mouth of Fish Creek, 2 or 3 miles nearly due north of the Jones mine, coal seams dipping in a southerly direction and continuous with the seams so well exposed along the road up Fish Creek were identified with certainty as representing the lower coal group. If there were no dislocation in the strata between these seams and those at the Jones mine, the dips would carry this lower group to a great depth below the coal of the Jones mine. It therefore becomes necessary to postulate another fault north of the Jones mine by which the outcrop of the lower coal group is duplicated in the direction of the dip. If, then, the 
coal at the Jones mine and the seams east of Mr. Whetstone's house belong to the lower group, they must be separated from the main basin to the south by one or more faults. Evidence in support of this hypothesis was found in the old placer pits on the Jones ranch near the mouth of Middle Creek, where displacement of the strata along a northwest-southeast line is clearly shown, but the amount of which could not be determined. The westward extension of all these faults is uncertain, but should be carefully studied and mapped by anyone attempting to mine coal in this disturbed region, for such displacements are likely to end a coal seam at any point.

The lower coal group, after crossing Trout Creek, is well exposed on the county road along Fish Creek, near the junction of Fish and Trout creeks. The beds dip toward the south. The following section, starting with this point as a base and extending southward so as to include the strata up to the middle coal group, is here given as illustrating well the character of the members that include the middle and lower groups of this district:

Section of coal-bearing strata taken along county road near junction of Fish and Trout creeks. $a$ Top.

Shales with thin bands of brown sandstone, containing Corbula undifera, Unio(?),

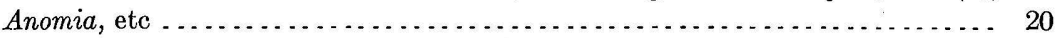

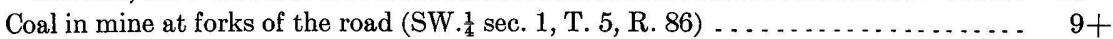

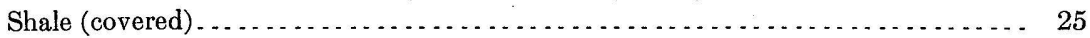

Talus with several heavy ledges of brown sandstone exposed . . . . . . . . . . . . . 100

Estimated interval of soft beds (mostly covered) . . . . . . . . . . . . . . . . . . . . 500

Sandstone, massive, soft light-gray, with bands of shale in middle portion and hard brown sandstone concretions near top . . . . . . . . . . . . . . . . . . . 40

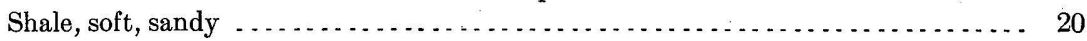

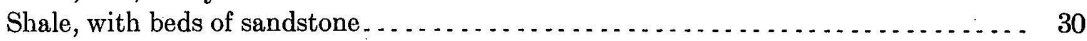

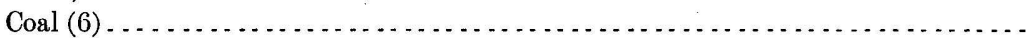

Shale, with nodular sandstone containing conifers, ferns, and dicotyledons ....... 8

Coal (5) . . . . . . . . . . . . . . . . . . . . . . . . . . .

Shale . . . . . . . . . .

Coal (4) . . . . . . . . .

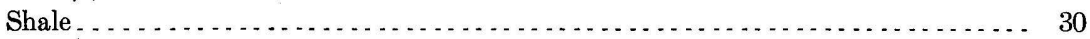

Sandstone, gray, weathered brown, alternating with shale . . . . . . . . . . . . 40

Shale . . . . . . . . . . . . . . . . 20

Sandstone, argillaceous, with fragmentary plant remains . . . . . . . . . . . . . . 8

Coal (3) . . . . . . . . . . . . . . . . .

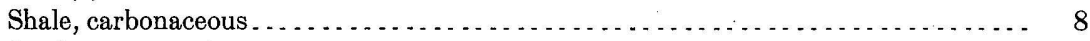

Sandstone, massive, gray ........................................ 8

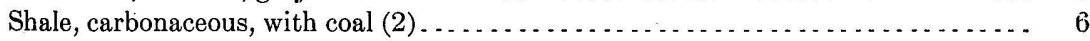

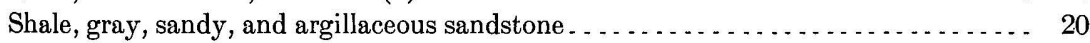

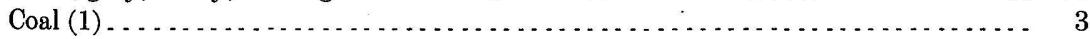

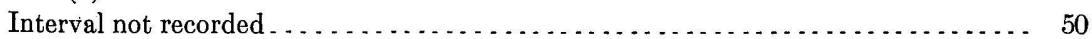

Sandstone, massive gray . . . . . . . . . . .

Soft (probably shaly) beds represented in talus slope .................... $200+$

$a$ Except the coals and other thin beds, which were measured as accurately as the exposures would permit, the thicknesses here given a re a.l estimates. Measurements by Dr. T. W. Stanton.

Bull. $297-06-4$ 
The coal near the top of this section belongs to the middle group and is mentioned later with the description of the seams of the Hutchinson property. The seams of the lower group continue northwestward along the eastern margin of the field, and the next developments of importance found along this belt are those on Yampa River in the vicinity of Pool.

Middle group.-From the Eddy district the middle group was followed southeast along its outcrop to where it joins with the same group of the Oak Creek district, as is indicated on Pl. I (pocket). To the northwest its direction was traced both by the coal prospects and outcrops and by means of its relation to the conspicuous outcropping ledges of the Trout Creek and Twentymile sandstone members.

This group of coals has been opened in many places. Probably the best known of these is on the Hutchinson property on Middle Creek just above the crossing of the public road west of Eddy. Here the principal seam shows a thickness of 9 feet 6 inches of clear coal in the mine near Mrs. Hutchinson's house. A sample for analysis was taken at a new opening a few rods down the creek. This sample was obtained by making a cut across the lower part of the seam, and it represents a thickness of 5 feet (see analysis C, p. 84). Another seam 25 feet below the Hutchinson seam has been opened a little farther down the creek, and judging from the appearance of the dump heap, considerable coal has been taken from it. This bed has a thickness of 6 feet 2 inches of clear coal.

To the north and northwest of the Hutchinson mines the middle coals are readily traceable along the county road. A mine already referred to in the section just detailed has been opened in a low gap at the intersection of roads from Eddy, from Dunkley, and from Steamboat Springs, which is about $1 \frac{1}{2}$ miles north a little west of the Hutchinson mines. A measurement of this seam gave 9 feet 10 inches of hard, shiny coal. The same group has been opened in a number of places near where it crosses Fish Creek, not far from the mine just mentioned. One of these openings north of Fish Creek exposes $4 \frac{1}{2}$ feet of clear coal, but the base of the seam is not shown. This seam lies stratigraphically about 250 feet above the Trout Creek sandstone, and may represent one of the seams shown in the Hutchinson openings. From the crossing of Fish Creek the middle coal group continues northward, and passing along this northeastern margin of Twentymile Park joins with the corresponding group in the Pool district, where the coals have also been opened in the valley of Yamp: River.

Upper group.-The coals of the upper group also outcrop in this end of Twentymile Park. One seam was found near the bank of Fish Creek across the hill west of the Hutchinson mine, but as exposed 
in natural outcrop it did not appear to be of importance. The distribution and outcrop of the upper coals in Twentymile Park has already been discussed (p. 39).

POOL DISTRICT.

General description.-At the mouth of Trout Creek the Twentymile basin extends to the north in the form of a narrow syncline (Pl. IV, $B$ ), and the coals of the middle and lower groups cross the Yampa River Valley. The situation will be best understood by reference to the map. There is thus available and accessible from the valley of Yampa River a district of somewhat limited extent, although known to contain some thick seams of good coal. Both coal groups have been opened. The properties locally referred to as the McCrosky, the Chrisney, the Hitchens, and the Brooks mines are probably the best known, and owing to their situation, which renders them readily accessible to the settlers of Yampa Valley, have been worked to a considerable extent, as compared with most of the development work that has been done in the Yampa field.

Middle group.-The middle coal group is mapped as extending continuously northward from both the eastern and western limbs of the Twentymile basin and, crossing Yampa River, as ending a half mile or so north of the McCrosky mine. The coal outcrops were not traced continuously along this belt, but the position of the coal group is inferred from the structure that was observed in the hogback ridges and the relationship of known coal seams to the strata that compose these ridges.

In crossing northward from Twentymile Park the first development encountered on this coal group is the Hitchens mine. This is situated on a side gulch entering Trout Creek from the southwest near its junction with Yampa River. It is a half mile farther up the gulch than the Brooks mine, to be described later, and is about 250 feet above the creek valley. This is a seam of the middle coal group and measured 10 or 11 feet in thickness. When visited, the entrance was locked and the roof in bad condition. There is no difficulty, however, in tracing the horizon of this seam along the face of the hill above the Brooks mine, where it is seen to be separated from the lower group of coals by an interval of at least 600 feet, composed mostly of the shales and weak sandstones which usually constitute the uppermost members of the lower division of the coal measures. Just 70 feet above the seam of the Hitchens mine was found a fossiliferous bed in the sandstone, carrying, among other fossils, Corbula undifera Meek., which has been found at a number of other localities overlying the principal coal seam of the middle group (see section, p. 23). From the Hitchens mine the outcrop of the middle coals extends northward around the face of the bluff and probably descends to water level on the banks of Yampa River. 
North of the river valley the middle coals were found in the vicinity of the property now owned and operated by Mr. Z. McCrosky and his son. At the time of visit the McCrosky mine was the only one in operation in the district. It is located in the SE. $\frac{1}{4}$ sec. 9, T. 6 N., R. 86 W. on the north side of the stage road $1 \frac{1}{2}$ miles west of Pool post-office. The coal is one of the lower seams of the middle group. It is used for domestic purposes and is hauled as far as Steamboat Springs. An entry had been driven in 400 feet, and the following measurements were made:

Section of coal bed in McCrosky mine, Yampa River.

Feet. Inches.

Sandstone roof

Coal, bony. $2 \frac{1}{2}-3$

Coal, good $4 \quad 8$

Coal, bony.

Clay.

Coal, good.

Coal; bony

Sandstone floor.

Total below upper bony coal.

A sample representative of all the good coal of this seam and another cut from the lower bench and representing only the 3 feet 11 inches. were taken (see analyses D and I, p. 84). The lower bench of coal was reported to be a good quality of blacksmithing coal.

This coal is one of several seams of the middle group showing in the face of the hill just north of the road. The sharp tilting up of the strata a short distance north of the McCrosky mine terminates the field containing the middle coal group, cutting off the seams in a flattopped triangular block, as indicated on Pl. I (pocket). The lower coals extend in outcrop in a narrow rim around this block. To the southwest of the McCrosky property the middle coals again cross Yampa River in outcrop. The Chrisney mine, on the south side of Yampa River, was not visited, but judging from the reports of it:; location it is thought that it may be opened on these coals. At this point the strata are tilted upon the east flank of the Tow Creek anticline, and in this relation their outcrop extends south to southwestwardly toward Grassy Gap.

Lower group.-The lower coals extend northward from the Eddy district, and the first development of consequence along this line is found at the Brooks mine, situated on the same gulch as the Hitchens mine, which has already been described. This has been opened on the uppermost of at least four seams exposed within a vertical interval. of 120 feet of massive sandstone beds. The coal seams of this group are here found interbedded with the most prominent sandstone ledges of the district. The Trout Creek sandstone, which has been 
described as occurring between the lower and middle coal groups of the usual stratigraphic section, does not show in this locality, and it is not certain whether it is absent or happens to be obscured by the débris on the hillsides. The coal bed measures slightly over 5 feet in thickness at the entry, and dips about $20^{\circ} \mathrm{W}$. A 4-degree slope runs down 100 feet, more or less, to the north and then turns along the strike of the bed. At this turning point the roof seems to drop about 2 feet, giving the appearance of a small fault. The roof is composed of a bed of white clay about 2 inches thick, overlain by a massive white sandstone. The seam shows a face of solid bright coal.

The lower coals on the north side of the river are well exposed in the tilted sandstone and shale beds outcropping on the stage road just east of Tow Canyon. Five or six seams show in the section, some having been burned at the outcrop. The following section was obtained from measurements along the stage road. It starts at the base with the sandstone ledges exposed near the house at the eastern end of the Tow Creek meadows, these ledges being assumed to represent the lowest hogback sandstone of the Mesaverde formation. The rocks dip uniformly east at an angle of $40^{\circ}$, and the horizontal distance across their outcrop having been obtained by pacing, the thickness of the beds is calculated.

Section of lower coal group and lower barren sandstone near Tow Creek.

Lower coal group: Five or six seams showing, including one massive sandstone ledge.

Strata below the lower coal group: Five distinct massive sandstone beds, or groups

of beds, with shaly intervals; thickness to the lowest sandstone exposed . . . . . 1,400

The river valley narrows at this point, continuing so for a half mile below, and then widens again for a mile or so, forming the broad meadows and terraces at the lower end of Tow Canyon.

Prospects north of Pool.-A small structural basin of coals of the lower group lies on the summits of the ridges a few miles northwest of Pool post-office. These coals have been recently prospected by drifts in a number of places, but the openings were not visited. A number of seams of workable thickness are reported, but the basin is a comparatively small one, and is not so readily accessible as are the coals in many other parts of the district.

\section{WILLIAMS · FORK MOUNTANNS.}

GENERAL DESCRIPTION.

The divide between Williams Fork and Yampa River is an upland, rising at its highest points, some 1,400 feet above Yampa Valley, at Craig, to an elevation of about 7,600 feet above sea level. The north slope is comparatively gentle, being approximately that of the rocks underlying it, although furrowed by drainage gullies. The top is 
covered by a dense growth of scrub oak and the lower slopes by sagebrush. On the south slope the eroded edges of the sandstone beds in the coal-bearing series stand out as cliffs and ledges, across which sharp narrow gulches cut back from Williams Fork. As explained on page 15, the Sage Creek anticline is a cross buckle of the strata that form the southern rim of the Yampa field, and as such interrupts the prevailing northward dip in the Williams Fork Mountains. Other irregularities in the structure occur in the vicinity of Craig. Southeast of the town several large masses of basalt have been thrust up through the sediments. There are also a number of subordinate folds or domes in the rocks that bring the coals to the surface in the river valley on both sides of Craig, but it is not known whether these domes owe their origin to igneous intrusions or to folding caused by lateral compression.

Near the junction of Williams Fork and Yampa River the structure is again complicated by cross folds, which are repeated within the next 8 or 10 miles west of the area shown on the map and which finally disappear beneath the overlying strata in the vicinity of Lay post-office.

This structural division of the Yampa field has been subdivided for convenience of description into various districts. These are:

1. Sage Creek Canyon.

2. Dry Creek district.

3. Hayden Gulch.

4. Other gulches north of Williams Fork.

5. Hamilton district.

6. Deer Creek district.

7. Yampa Valley below Craig.

8. Yampa Valley near Craig.

9. Lay district.

SAGE CREEK CANYON.

A little over 5 miles south of the town of Hayden, Sage Creek emerges from a canyonlike valley eroded on the axis of a prominent anticlinal fold. This fold, like the one on the west of Twentymile Park, is not symmetrical, having a steep dip on the east flank, and a much lighter dip to the west. The erosion of this valley has exposed an unusually complete section of the coal series, and all three groups outcrop as represented on the map (Pl. I, pocket).

At this point coal seams belonging to the upper coal group immediately overlie the lower ledges of the Twentymile sandstone member. From this horizon upward through the next 400 feet of strata coal indications occur at intervals, and at least four workable seams in the upper part of the group are exposed at the mouth of the canyon. 
The section of the upper coal group therefore presents considerable variation from the section observed at Foidel Canyon in Twentymile Park, where the coal was noted only some 200 feet above the main ledge of the Twentymile sandstone. It is evident that the upper coal group is an economically important member of the Mesaverde formation in the vicinity of the Sage Creek anticline. The topmost or 11-foot seam of the upper group has been mined at a point on the north slope of the anticline, outside of Sage Creek valley, but the mine was not visited.

Two thick seams of the middle group have been opened a short distance above the mouth of the canyon. One of these entries is known as the Barnes mine. The other is about 100 yards farther west. The remaining openings in this district are mainly in the nature of surface prospects.

The Barnes mine is a drift which runs in to the south-southeast for 300 feet, following the strike of the coal seam. The seam dips $28^{\circ}$ northeasterly. At the time of visit Mr. J. J. Barnes was working in the mine and the coal was being hauled to Hayden. He explained that work had recently been abandoned at the breast of the drift on account of a "slack streak" which had been encountered at this point and which he connects with a break or slump showing on the surface of the ground above. With his help a sample was taken from the upper end of the stope, where a fresh face had just been exposed by blasting. The seam measured 6 feet 10 inches. A 50-pound sample cut from this face was carefully pulverized and quartered for analysis (see sample N, p. 84). An apparently local bony streak of 2 or 3 inches about a foot from the base of the seam was thrown out.

Underlying the Barnes seam by about 75 feet stratigraphically is another thick coal seam, which is believed to be the same as that measuring 12 feet, one-half mile farther up the valley (see section, p. 27). This second seam is opened by a drift of about 40 feet, and was reported to be 11 feet 5 inches thick. This measurement was apparently correct, although at the time of visit it was found difficult to determine the exact thickness. Five feet of shale composing the roof was exposed at the entrance. This seam was also sampled, and the analyses show the two seams at this point to be of very similar composition. These openings are on the eastern or steep side of the anticline. On the west side the same seams and a third seam of the same group have been opened by prospect pits one-half mile farther up the creek. The outcrop of this group of coals can readily be traced southward along the canyon walls, rising higher as one goes upstream and exposing lower and lower rocks at water level.

Lower group. - A mile or more south of the prospects last mentioned are openings on three or four seams of the lower group. One of the seams was reported as 10 feet thick, but could not be measured at the 
time of visit. These were on a small side gulch, and were also on the eastern or steep side of the anticline, dipping $35^{\circ} \mathrm{NE}$. A rough measurement of the thickness of the strata intervening between the middle and lower coal groups gave an interval of 650 feet.

\section{DRY CREEK DISTRICT.}

Dry Creek flows northward in a course approximately parallel to that of Sage Creek, but 2 or 3 miles farther west, entering Yampa River at the village of Hayden. It drains the west flank of the Sage Creek anticline, and as its name indicates, it is dry during the summer season.

The coals exposed along Dry Creek are of the upper group and lie against the west flank of the Sage Creek anticline. These seams have been opened at a number of places. In the NE. $\frac{1}{4}$ sec. 4 , T. 5 N., R. 88 W., three entries have been made, one of which, known as the Dry Creek bank, was being worked at the time of visit by Mr. S. A. Adair, to supply the Hayden market. This mine was opened by a slope driven down on a seam that dips $14^{\circ}$ to $15^{\circ} \mathrm{NW}$. The face of the mine showed 7 feet 10 inches of good coal, separated by a small parting about 1 inch thick from some 3 feet more of coal above, which, however, was left to serve as a roof. A sample of the seam as mined was taken for analysis (see analysis P, p. 84).

An abandoned drift near by had been driven in the direction of the dip of the seams, and starting below the outcrop of the coals had cut through the three large seams of the upper group in this district. This drift gave an excellent opportunity to measure the seams and the intervening strata. The uppermost of the three seams was the one opened in the Dry Creek bank just described. The following section was obtained:

Section of upper coal group on Dry Creek.

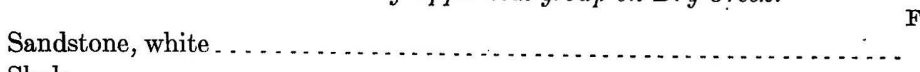

Shale . . . . . . . . . . . . . . .

Coal . . . . . . . .

Parting . . . . . . .

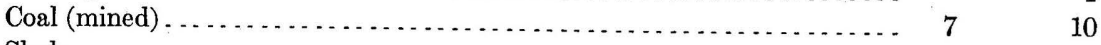

Shale . . . . . . . . . . . . . . . .

Coal . . . . . . . .

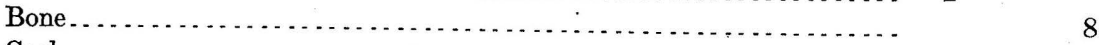

Coal . . . . . . . . . . .

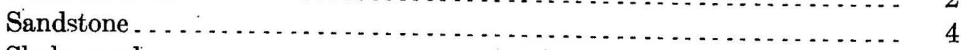

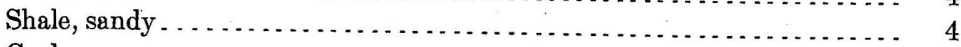

Coal. . . . . . .

The third or southern entry of the three was reported to contain gas and to be caving dangerously, and therefore was not entered. These openings are all just north of Mr. W. M. Carlyn's ranch. A little over 
one-half mile farther north the outcrops of these seams cross the creek valley and pass along the north face of the ridge to the mouth of Sage Creek canyon, already mentioned.

All along Dry Creek from these coal banks southward to the head of the creek the massive white ledges of the Twentymile sandstone that mark the base of the upper coal group are conspicuously exposed. The coal seams themselves are marked by reddened shale and sandstone resulting from burning of the outcrops. No reason is known why coal banks opened at any point along this gulch should not show seams as thick as at the few points already developed. The burning at outcrop is not thought to extend to any considerable depth, probably never beyond ground-water level.

\section{HAYDEN GULCH.}

After crossing from Dry Creek to the drainage basin of Williams Fork the county road follows down Hayden Gulch. Here a complete section of the three coal groups, together with the series of barren sandstones below the coals, is well exposed in outcrop. The trend of the outcrop here changes from its north-south direction on the western flank of the Sage Creek anticline to nearly due west.

About one-half mile south of where the road passes through the gap at the head of Hayden Gulch, on the west side of the road, two or more seams show in small prospect pits. These are clearly members of the upper group of coals overlying the very massive white Twentymile sandstone member. Below this sandstone a prospect pit shows one of the seams of the middle group, while the presence of others of the same group is indicated by a belt of burned shale and sandstone. Still lower and about 1 mile from the mouth of the gulch the lower coal group crosses the road. Two openings̀ of considerable size have been made, one known as the Green mine, on the west side of the road, and the Scott mine, on the east side.

The Scott mine is opened on a thick seam and shows a face of 9 feet 2 inches of good coal overlain by 4 feet of shale. The coal has been worked out in a broad chamber, the roof of which had caved badly and was in a dangerous condition when visited.

The Green mine was opened by an entry ending in a large chamber and exposes a fine face of coal 10 feet thick. The roof is formed by a strong sandstone 2 feet thick. It is estimated that this seam is 100 feet stratigraphically below the Scott seam. A sample was taken from the breast of this entry. (See analysis Q, p. 84.)

OTHER GULCHES NORTH OF WILLIAMS FORK.

Hayden Gulch is typical of many other gulches that head back toward the Yampa River divide from Williams Fork. The public road down Williams Fork follows along almost directly below the lowest 
sandstone hogback of the barren series, which can be traced continuously for a number of miles. Thus the side gulches cut back across the strike of sandstones and coals, and as most of them are deep and sharp and their stream beds of fairly easy grade they afford ready access to the coal seams exposed along their courses. Few of these gulches were explored in detail, as each was very like all the rest. Berry Gulch, just below Pagoda, leads back to an old working on one of the coal seams of the lower group, which had apparently been abandoned for some time.

In Deal Gulch, which is followed by the mail route between Pagoda post-office and Craig, openings have been made on two seams of the lower group. On one of these a drift has been run in 50 feet on the lower seam. The section of the coal bed exposed by this drift is as follows:

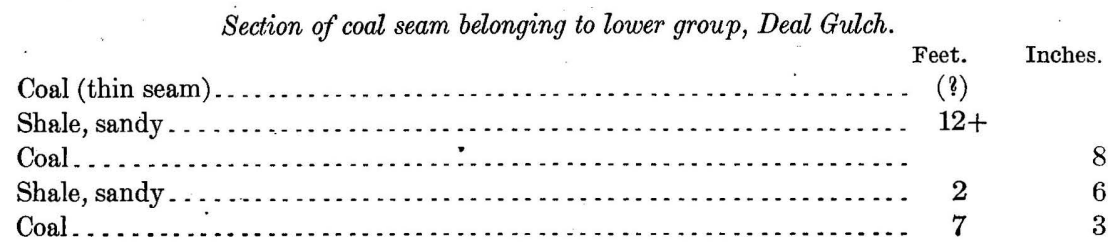

\section{HAMILTON DISTRICT.}

In the vicinity of Hamilton post-office shale and sandstone, reddened by burning coal seams, show in the bluff on the north side of the river. All of these seams are evidently lower coals, as the usual hogbacks of lower barren sandstones were observed to underlie them in normal succession, although the apparent sequence is somewhat distorted by folding.

Before the present stage road to Craig, following down the canyon of Williams Fork, was built, the route of travel was by way of a gulch opening opposite the mouth of Morapos Creek, just below Hamilton. A short distance up this gulch coal seams of the same horizon as those noted at Hamilton are exposed in a number of prospects, but none of any considerable thickness were noticed, although it is quite probable that they exist. Two miles below Hamilton, on the west bank of Williams Fork, is another prospect apparently on this same coal group.

Between the seams at Hamilton and the strata outcropping in Axial Basin there are five distinct, and in most cases massive, ledgemaking sandstone members, showing as hogbacks with shale valleys intervening and conformably underlying the coals. The sequence of the lower "barren" sandstones at this point is apparently similar to the development of this group in other parts of the field, even to the details of its ledge-making sandstones, as observed, for example, all along the valley of Williams Fork and at Dunkley Canyon. 
There is, however, some uncertainty as to the definite limits of the lower coal group in this portion of the field, and it seems likely that the coal is here distributed through a greater vertical range of strata than has been noted in other portions of the field. The section measured in the canyon of the Yampa below the mouth of Williams Fork (p. 61) shows coal seams for an interval of at least 400 feet. The following tentative note was recorded at this place: "There seem hère to be two coal groups in what has been previously called the lower coal group. The upper (burned) group shows well on the north side of the river west of the bend and reaches almost up to the Trout Creek sandstone, which is again capped by a burned group."

Two miles aast of Hamilton post-office coal seams outcrop on both sides of the public road and of Williams Fork. Folding of the strata south of this region brings down the coal-bearing strata into one or more subordinate basins outside of the main coal field. From the mouth of Deal Gulch westward the hogbacks of the lower barren sandstones sag until the lower coal group is brought down to water level. The coal seams were found outcropping on the sides of Badger Gulch, which opens into Williams Fork from the south at this point, some 2 miles east of Hamilton. Where the coal seams cross the river at least three seams are exposed, ranging in thickness from 2 to 3 feet. One of these seams thickens toward the east and affords a good mine in the mouth of Badger Gulch on the south side of the river. The seam is here 5 feet thick and except for a thin lens of bone all the coal is hard and bright. The tunnel has been driven about 50 feet and a broad room is opened beneath a good roof.

\section{DEER CREEK DISTRICT.}

Thick coal seams and much prospecting are reported on Deer Creek, which is a tributary to Morapos Creek, situated in the east end of Axial Basin. Deer Creek Valley was not visited by any of the party and is not represented on the map, but a number of prospects just over the divide to the north of Deer Creek were visited and mapped. All of these prospects are thought to lie within the subordinate structural basins or troughs of the folds already mentioned (p. 15) as occurring in this part of the region. The openings visited are clearly a part of a narrow synclinal basin just deep enough to include coals of the lower group, but evidently widening and deepening toward the east.

The most important of these openings is the Kellog coal bank, which was being worked for domestic use in Axial Basin at the time of visit. An entry had been driven in 200 feet, showing a clear face of coal at least 15 feet thick with coal roof and coal floor. It is thought that the seam itself may be several feet thicker, as at present only 
such portion of the coal as can be conveniently reached has been mined out. The rocks here dip about $5^{\circ} \mathrm{NE}$., while scarcely onefourth mile down the gulch in about the direction of this dip a similar very thick seam of coal is found dipping back $34^{\circ} \mathrm{SE}$. These are possibly the same seam; at least they are evidently on opposite sides of a syncline.

Other properties near by are opened alongside of the old Government road that was originally built to cross by way of these gulches from the Ute Indian Agency at Meeker, passing down Badger Gulch to Williams Fork, and thence to Yampa Valley. These coal properties are now being exploited by Messrs. Thomas H. Hamilton and W. L: Jameson. An opening on the uppermost seams is not now accessible, but, according to Mr. Jameson, when opened it exposed a seam over 23 feet thick with a small bony parting showing about 4 feet from the top. The strike of the rocks is N. $25^{\circ} \mathrm{E}$., with an easterly dip of approximately $20^{\circ}$.

An opening a short distance farther down the gulch on the south side of the old road gave the following measurement:

Section of coal at opening on Hamilton-Jameson properties near Deer Creek.

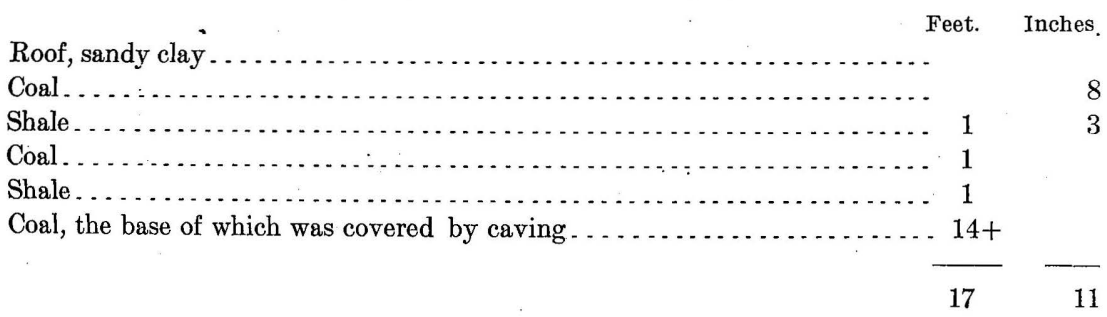

There are several small partings which are not constant. The rocks strike $\mathrm{N} .75^{\circ} \mathrm{E}$., with a southerly dip of $34^{\circ}$.

It is thought that the seams of this district would be found conthuous with those of the openings at the mouth of Badger Gulch on Williams Fork, as the trend of the formations was seen to swing in that direction, but this can not be stated positively without more complete knowledge of this portion of the field.

\section{YAMPA VALLEY BELOW CRAIG.}

Near the junction of Williams Fork and Yampa River there have been opened a considerable number of prospect pits and drifts and several well-developed coal banks to supply local demand. These expose seams of all three coal groups. The properties are locally known as the Greeley prospects, the Wise bank, the Ratcliff bank, the Haubrich bank, and the Wood mine.

Lower group.- In the canyon of the Yampa just below the mouth of Williams Fork there are a considerable number of drifts opened 
on seams of the lower coal group and known as the Greeley prospects. Measurements that were made at this place indicate that at least seven different seams of coal were exposed, all within the lower group and distributed through a stratigraphic interval of 350 feet. Rough measurements of these seams from the uppermost down were as follows:

Section of lower group on Greeley property in lower canyon of Yampa River.

Trout Creek sandstone.

Feet. Inches.

1. Interval, estimated.

$250-300$

2. Coal, burned in outcrop.

3. Interval 75

4. Coal

5. Interval 4

6. Cogl, indeterminate $50 \pm$

7. Intervol . . . . . . .

8. Coal

9. Sandstone and shale

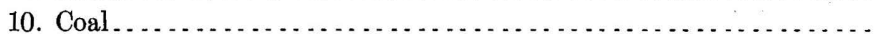

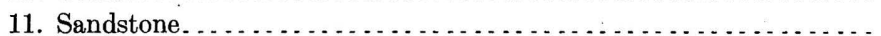

12. Coal

13. Sandstone, thick-bedded

14. Coal.

15. Sandstone, massive

All of the openings were in very bad condition owing to caving, and thus the measurements are somewhat uncertain.

Middle group.-Ascending the small gulch on the northwest side of Yampa River, opposite the Wise farm, the middle group of coals is found in natural outcrop just above the massive ledges of the Trout Creek sandstone. Six coal seams show at this place, one of which appeared to be at least 7 feet thick and another about 10 feet thick. No work has been done in the development of these upper seams, and the measurements are therefore very uncertain.

The Wise coal bank is situated close to Williams Fork, about 1 mile due south of the mouth of this stream. The mine is opened on a seam of the middle coal group and was not in operation when visited. The opening showed 8 feet of coal under a shale roof. The actual thickness of the seam may be somewhat greater.

The Ratcliff bank opens a seam also of the middle group, but evidently overlying the Wise seam by a considerable interval. This opening is on a school section, and, when visited, was being worked under lease by Mr. Joseph S. Blamey. Most of the coal taken out was being hauled to Craig. The opening was driven in 400 feet; it is timbered with long poles set about 3 feet apart, but the roof has caved badly in places. The mine is fitted with a 1-ton car and a 
small wooden-frame tipple. Measurements of the seam showed 10 feet 7 inches of coal without partings, of which, however, the lower 16 inches was not mined. A 4 -foot seam is reported about 50 feet below this seam.

Upper group.-The Joseph Haubrich bank, on Yampa River, just above the mouth of Williams Fork, was opened for private supply. The bank showed a thickness of 6 feet 4 inches of coal and has a shale roof. This coal lies just above the massive white Twentymile sandstone that marks the base of the upper group.

Middle coals at Big Bottom.-Near Wood's ranch, or "Big Bottom," on Yampa River, about halfway between the mouth of Williams Fork and the town of Craig, the river bed cuts through a low anticlinal fold, exposing along the river bank coals thought to belong to the middle group. Some six seams outcrop here, several of which appear to be of good workable thickness, although no good measure could be obtained from the present exposures. A large seam outcropping in the river bank near an engine house has evidently been used to furnish steam coal for the boiler of this pumping plant. The plant was said to be intended for the irrigation of the large meadows on Big Bottom.

\section{YAMPA VALLEY NEAR CRAIG.}

Two mines, namely the Walker and Kimberly banks; have been opened on coal seams that were at first assumed to belong to the upper coal group. They are represented on the map as belonging to the upper group of the Mesaverde formation. There is, however, a strong probabilty that these coals and associated strata should be classed in the Laramie formation and not with the Mesaverde coals at all. Massive sandstones in the vicinity of Craig show in many escarpment ledges which strongly resemble the typical exposures of the Twentymile sandstone.

The Walker bank is on the south side of the river, about 4 miles southeast of Craig. The seam measures 8 feet, and possibly more, of good solid coal. The coal breaks out in cubical blocks and is without partings. This bank was opened sixteen years ago and is úsually worked during the winter season. Another seam, exposed about 25 feet lower, is apparently about 4 feet thick.

The Kimberly bank is on the north side of the river and about 2 miles east of Craig, near the stage road. The opening shows 8 feet of solid coal, but the seam is probably slightly thicker, as neither roof nor floor is exposed. It dips $14^{\circ} \mathrm{N}$. and has been opened by a slope starting from the surface outcrop. The coal is much weathered near the entrance, but distinctly improves in quality toward the end of the 150-foot slope. 


\section{LAY DISTRICT.}

Westward from the mouth of Williams Fork the intervals between the several coal groups decrease notably. A short distance east of Lay the three groups are embraced within a vertical range of 800 feet. The middle and upper groups have been prospected but little. Near Lay post-office, within a vertical range of 250 feet, three coal seams have been opened whose aggregate thickness is 41 feet. An additional 4-foot seam is believed to exist in the same interval and a 10-foot seam 60 feet higher, making in all 55 feet of coal within a range of 320 feet.

An entry (called the Sweeney tunnel) on the lowest seam exposes 7 feet 10 inches of coal, separated into two nearly equal parts by a 12-inch streak of bone. Beneath a thicker layer of bone, now used as the floor of the mine, another bench of good coal 4 feet thick is reported. One hundred feet above the Sweeney seam is the so-called Peacock seam. Here are 9 feet of coal, unfortunately covered by a poor roof of clay. A 4-inch layer of bone appears near the top and locally another is found near the bottom. The coal is otherwise clear, bright, and very tough. One hundred feet higher is a double seam, containing 20 feet 3 inches of coal, divided into two nearly equal parts by a 15-inch layer of shale. Mr. A. G. Wallihan, of Lay, the local representative of the Wisconsin Fuel and Mining Company, has driven a broad tunnel about 200 feet into the lower part of this seam. Blacksmith's coal is sent from this mine as far as Hayden, a distance of 45 miles. Simple tests made by Mr. Wallihan lead to the hope that this will prove to be a coking coal.

\section{WOLF CREEK DISTRICT AND ANTHRAGITE RANGE.}

\section{GENERAI. DESCRIPTION.}

The third structural division of the Yampa field may be roughly defined as extending from the vicinity of Wolf Creek Valley, northward through the Anthracite Range. This is the eastern rim of the main field and includes a belt of territory of almost due north-south trend, from 2 to 4 miles in width and about 28 miles long. The coal seams outcropping along the eastern rim of the main structural basin of the Yampa field have the same structural relations as those of the Williams Fork Mountains along the southern rim. The region thus described lies between Grassy Gap and Twentymile Park on the south and Sand Mountain and California Park on the north. The coal-bearing rocks and the coal seams dip to the west, passing beneath the younger rocks that occupy the center of the field, and are in all probability continuous beneath Hayden Valley with the formations of the Williams Fork Mountains. 
The southern half of this district, which is that included between Grassy Gap and Wolf Mountain, is a simple structural unit, namely, the western flank of the Tow Creek anticline. At the head of Wolf Creek the outcrops of coal seams are interrupted by the basaltic intrusions of Wolf Mountain. The coals appear again north of Wolf Mountain, but the upper and middle coal groups are again interrupted by the intrusive masses about Pilot Knob. The lower coal group appears to outcrop continuously along the east flank of the Pilot Knob intrusion, having the normal westward dip of this portion of the field. It seems probable also that representatives of all three groups could be found again north of the Anthracite Range, but this has not been satisfactorily established.

For convenience these coals will be described under two headings:

1. Yampa Canyon and Wolf Creek district.

2. Anthracite Range.

\section{YAMPA CANYON AND WOLF CREEK DISTRICT.}

Upper group.-All three coal groups are represented by the seams outcropping in the vicinity of the canyon of Yampa River, 7 miles or more above Hayden. Just north of the steel bridge across the river at the mouth of the canyon is an abandoned mine opened on a seam of the upper group. A dump heap showing a considerable amount. of slack and an old wooden chute leading down to the roadside show that coal has been mined for use from this seam. Measurements at this mine are as follows:

Section of seam of upper group at mouth of Yampa Canyon.

1. Roof, clay shale.

Feet. Inches.

2. Coal. 8 to 12

3. Shale, yellow sandy 1

4. Shale, blue-gray . 11

5. Shale, fine brown . . . . . . . . . . . . . . . .

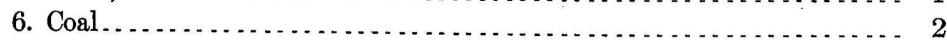

7. Parting -

8. Coal.

The seam mined was 3 feet, including the $\frac{3}{4}$-inch parting. An entry was driven in 100 feet or more, but is now badly caved, letting down the bowlders and gravel of the surface slope above and showing that the seam itself is poorly covered.

Middle group.-A fairly complete section of the middle group is exposed in the canyon at the mouth of Wolf Creek. There are at least four seams exposed, with the probability that more small seam. are concealed. The uppermost is a small seam known as the Lennox seam. Under this are about 70 feet of sandstone and shale, then the 
coal known as the Wadge seam. About 90 feet stratigraphically below the Wadge seam is a thick coal known as the Wolf Creek seam. Approximately 100 feet lower still is a small seam of unknown thickness partly exposed at the top of the TroutCreek sandstone by the side of the public road.

The Lennox seam is opened by a shallow prospect on the south bank of the river a short distance downstream from the Wadge openings. This coal was reported by Mr. Sam G. Adams to be of exceptional quality, but no sample was obtained for analysis. The seam measured something less than 3 feet in thickness. The entry receives its name from its location on a property known as the Lennox tract, which is situated on the south side of Yampa River in this vicinity.

The Wadge seam has been opened by two entries on the south bank of the river directly opposite the mouth of Wolf Creek. This coal reeeived its name from the man who first exploited the district, and who owns the ranch on the river bottoms near by. A mine on this seam has been worked for domestic use in the vicinity. The old drift was driven to a depth of about 250 feet. At the time of visit, however, another drift on the same seam was being driven in a short distance west of the old entry. A sample for analysis was taken from the face of each entry (see analyses $K$ and $O, p .84$ ). The seam measured 8 feet 3 inches of clean, hard, bright coal, apparently without partings. The coal is reputed to withstand weathering and transportation exceptionally well, and is locally known as one of the most perfect seams in the field.

On the north side of the river an entry has been driven beneath the stage road opening up a thick seam of coal nearly opposite the Wadge bank. At the time of visit this mine was not in such shape that an accurate measurement of the coal could be made, but the bed has frequently been referred to as a "20-foot" seam. The face exposed showed a lower bench of coal upon which the entry had been driven, and an upper bench of 8 feet of coal, the two separated by a 15-inch sandy parting, making a total thickness of 16 feet 3 inches, as nearly as it was possible to measure. As the face exposed did not appear fresh, no sample was taken for analysis.

Lower group.-A little over a mile northwest of the Wolf Creek and Wadge banks several seams of the lower group outcrop by the side of the public road. The Trout Creek sandstone member stands out conspicuously near the top of the bluff above; the stratigraphic interval between it and these lower coals was roughly estimated as 400 or 500 feet. At least five seams show very close together in a road cut. One measures approximately 4 feet in outcrop and the others are apparently small. Here, as at other points near water level, it is

Bull. $297-06-5$ 
recognized that outcrop measurements may be very unreliable regarding the actual thickness of a coal seam, and that the coal may appear to be thinner than it actually is. It is possible that the less resistant coal may be squeezed out by the weight of overlying rocks or weathered out, allowing the rocks above to sink down. There is some reason to think that this has taken place where the Wolf Creek seam outcrops on the bank of Yampa River, for this coal, which shows in the entry near by more than 16 feet in thickness is said to show as a 1 or 2 foot seam near the river bank. The same principle may explain the thin seams that represent the lower group where they cross the stage road, as described above, for in a near-by locality the lower group is known to contain a number of seams thicker than those here reported. The coals are frequently burned along the outcrop, and then their exposures are very deceptive. An old entry on the south side of the river was opened on one of these seams, and is reported to have gone in along a streak of ashes and cinders for some distance and then to have struck a thick seam of coal.

Butcherknife Creek.-The outcrop of the lower coal group extends north from the Yampa Canyon, crosses a small ridge, and follows up the valley of Butcherknife Creek. A wagon trail up this gulch crosses at the head and passes down to the west into the Wolf Creek Valley. In the upper valley of Butcherknife Creek Mr. F. H. Gartman has opened a number of prospect drifts, and from one of these a sample for chemical analysis was taken (see sample L, p. 84). This seam measured in all 6 feet 4 inches, including a 4-inch bony streak, which separated 6 inches of coal below from the rest of the seam. This entry was about 30 feet in length, showing the rocks to be striking nearly north and south and dipping $15^{\circ}$ westwardly. A section measured near by is as follows:

\section{Section in the lower coal group, upper Butcherknife Creek.}

Not exposed above.

1. Coal poorly shown, top not certain.

Feet. Inches.

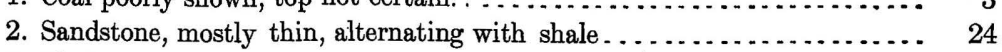

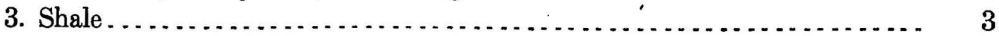

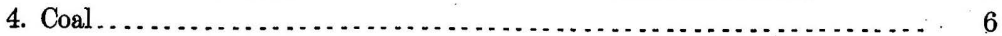

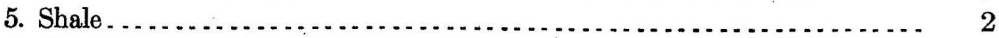

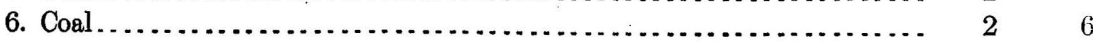

$41-4$

A 3-foot coal seam showing in the opening on the opposite side of the gulch was estimated to lie 85 feet below the base of the above section.

Wolf Creek Valley.-Wolf Creek drains soutb from Wolf Mountain and joins Yampa River 7 miles east of Hayden. In its upper course it flows in a narrow canyon through the massive sandstones underlying the coal groups. Below this canyon it cuts diagonally across the 


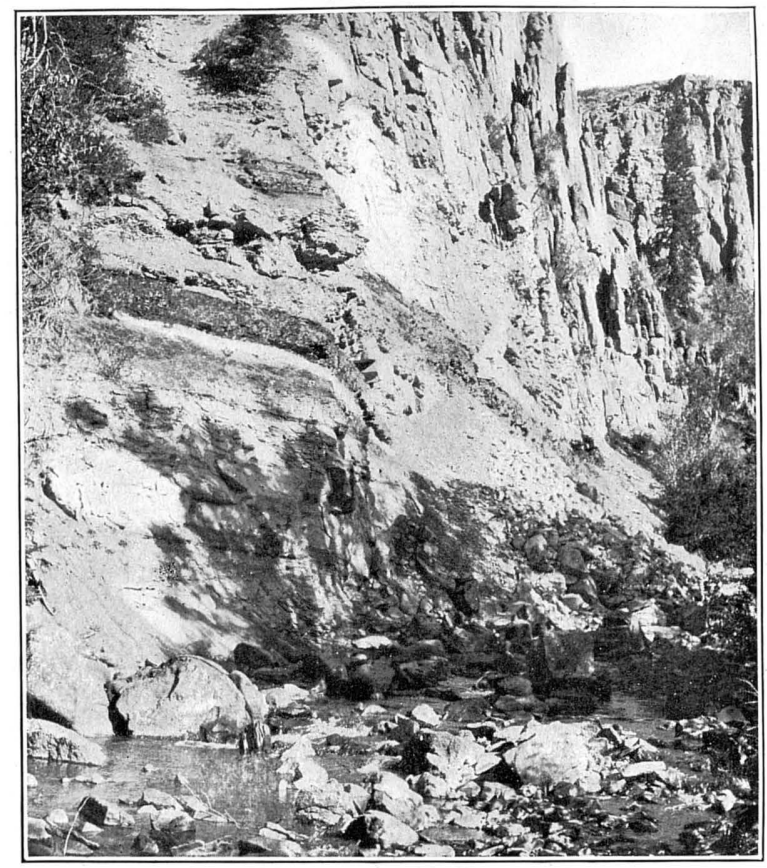

A. ANTHRACITE COAL SEAM AND OVERLYING IGNEOUS SHEET AT "THE POTHOLES" ON ELKHEAD CREEK.

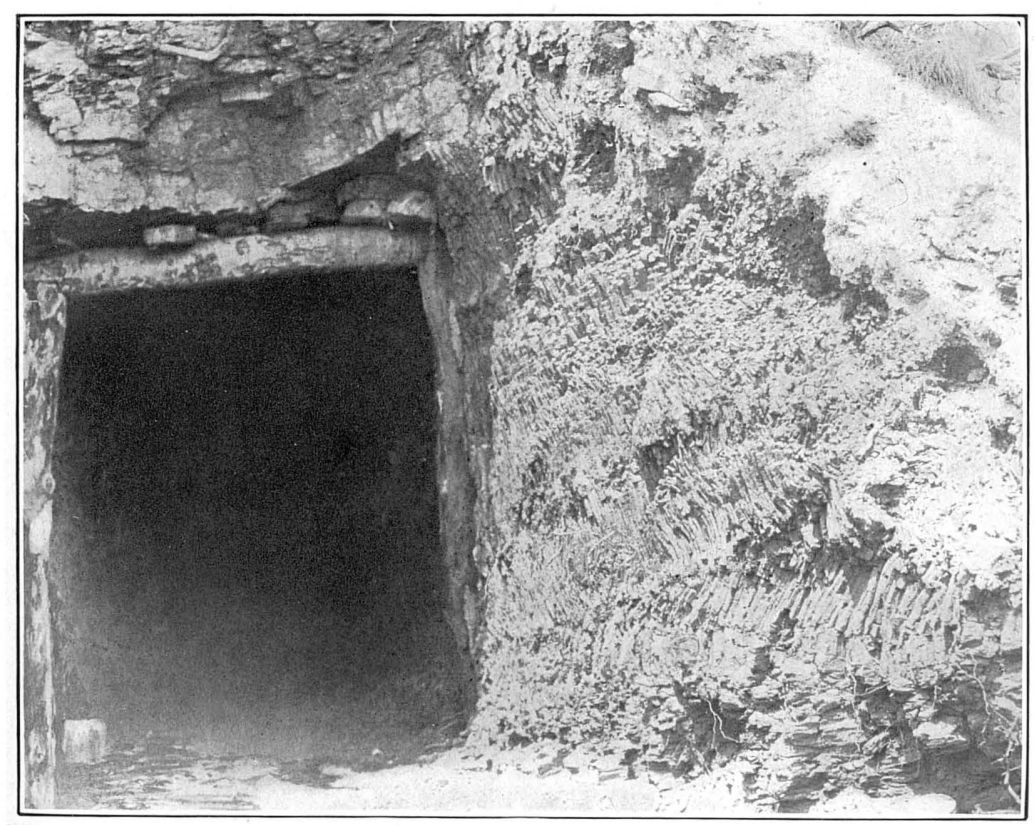

b. COLUMNAR COAL SEAM ON UPPER WOLF CREEK. 

outcrop of the lower coal group, and these coals have been recently opened in a number of prospect drifts. One entry about 40 feet in showed a face of 4 feet 2 inches of good coal between clay-shale roof and floor. The dip is $8^{\circ}$ or $9^{\circ} \mathrm{SW}$. Another entry near by shows either the same seam or one very close to the same horizon, measuring 6 to 8 inches of coal above a thin parting and 3 feet or more of coal below.

Between the outcrop just described and those of the lower coal on Butcherknife Creek there were found two or three prospects on this same group on a gulch which is tributary to Wolf Creek, and which is followed by the wagon trail from Butcherknife Creek. One drift had been opened on the north side of the gulch, showing a seam at least 6 feet 4 inches thick, including two or three thin partings. This was separated by 8 inches of clay shale above from another seam of coal 1 foot or more in thickness. The roof was not firm and required much timbering. The drift runs into a small spur between two gulches in a direction about $\mathrm{N} .35^{\circ} \mathrm{E}$., and rises slightly with the rise of the seam.

Throughout this portion of the field the positions of the various coal groups are distinct'y marked by the conspicuous escarpments of the Trout Creek and Twentymile sandstones, which may be followed in almost unbroken continuity throughout the district.

In the lower 4 miles of its course Wolf Creek follows almost directly upon the outcrop of the coal seams of the middle group. Openings along this course show seams of coal apparently resembling the seams described at the mouth of Wolf Creek, both in character and position, and it is thought that several of these seams could be traced through continuously.

Under the flanks of Wolf Mountain on a west fork of Wolf Creek a number of prospects on coals of the middle group were also found. One of these is of especial interest on account of the peculiar structure of the coal that it shows. The entry is abuut 100 feet in depth, exposing a seam about 5 feet thick, jointed with a most perfect columnar structure. This has been called the "reed seam" through a fancied resemblance of these joint columns to reed stems (Pl. IX, $B)$. The jointing is of the hexagonal type and stands approximately vertical, that is, perpendicular to the walls of the seam. Near the mouth of the entry the whole seam shows the jointed structure, and the columns or prisms average perhaps 1 inch in diameter. As the drift passes in upon the seam, however, the jointing is seen to be more perfect in the upper half, while the whole seam has the minutely vesicular, glistening appearance of coke. In spite of considerable search no igneous rock was found above or below the seam, but it seems certain that this must be the result of proximity to a lava intrusion, which must have been at no great distance and lying above the coal seam. 
An occurrence so similar that hand specimens from the two localities could scarcely be distinguished was noted by Mr. J. A. Taff in eastern Utah. In this latter instance a dike of igneous rock cut directly across the coal, the columnar jointing being developed for a distance of 2 or 3 feet from the contact.

\section{ANTHRACITE RANGE.}

Volcanic phenomena.-The northern border of the Yampa field, including a portion of its eastern margin, has been the seat of a great amount of eruptive activity. Eruptive rocks compose, to a large extent, the high peaks of the Elkhead Mountains and the lesser peaks of the Anthracite Range. Pilot Knob and Wolf Mountain are the most prominent points of the Anthracite Range and form a rather high and rugged divide separating the waters of Deep Creek and Elk River on the east from the drainage of Elkhead and Morgaz creeks on the west. In the Anthracite Range the principal intrusions have occurred at the horizon of the coal-bearing series, and it is to this relation of igneous rock and coal seams that the coal owes its character and the district its name.

The heat accompanying the intrusion of molten rock has influenced to varying degrees the character and composition of the coal seams that lay adjacent." In general the effect of this baking process on the coal seams has been to drive off the volatile hydrocarbons more or less completely. In this way all grades of coal, ranging from bituminous to anthracite, have been formed. So far as observed, dikes cutting across a coal seam do not seem to have altered the coal farther than a few feet on either side of the contact. The maximum effect probably resulted where the igneous sheet lay parallel to the coal seams. Naturally the amount of alteration would vary with the distance of the coal from the basalt, as well as with the size and thickness of the sheet which afforded the heat. It is claimed by observers who have studied this process in other fields that the baking is extended to a greater distance, and is more complete above a horizontal igneous sheet than below it. Instances in which close observation of these relations could be made in this field were so scattered, and apparently included such a number of variable factors, that the law as stated above was not clearly corroborated.

So far as is known the intruded lava sheets have not exerted any marked influence through more than 50 to 70 feet of intervening strata, and probably not often so far as this. A contact of coal and lava would probably have resulted in burning or complete coking of the coal. Beyond this zone of burning there is probably a range from maximum anthracization near by to little or no alteration at a distance. In order that any given seam may be changed to good anthracite there is necessary a comparatively delicate adjustment of this 
relation of coal seam and lava sheet, the achievement of which depends upon purely accidental circumstances. Thus, while the coalbearing rocks have been disturbed by volcanic intrusion to a considerable extent over a large area extending from the vicinity of Wolf Mountain to the northern extremity of the field, and while this whole district is designated the anthracite field, it is known that a large part of the coal within this area is not changed to anthracite, and it is not probable that the exact combination of conditions necessary for such change was very general throughout the area. The most extensive igneous sheet observed and known to lie close to an important coal horizon is that which outcrops as the great "rim rock" (p. 72) on the east side of the range extending from California Park to near Deep Creek, a distance of about 4 miles. As described on page 72, this sheet is overlain in part at least by anthracite coal.

The anthracite field is now divided into a considerable number of private holdings, details relating to the ownership of which were not investigated. It is convenient, however, to make use of certain local names, by which the various tracts have been known in the past, although they may not now be significant as to present ownership. The best known of these districts are: The Crawford tract,the Morgan tract, and the Shelton tract. Besides these there are also the properties at the head of Miller Gulch, extending north to Ducey tunnel, and the property in California Park, on the flanks of Sand Mountain.

Crawford tract.- The property known as the Crawford tract is situated on the public road that crosses the Anthracite Range west of Anthracite post-office. The seams of this tract are thought to belong to the middle coal group, and are so shown on the map (Pl. I). Openings on the seams of this tract are perhaps the best known of any in the anthracite field. Three entries are located close to the public road. The two uppermost on the roadside and another on a small side gulch to the north of the road appear to be on the same seam, which measures approximately 11 feet in thickness, including a parting of 6 to 8 inches near its middle. A massive sheet of basalt is plainly exposed on the north side of the creek, dipping under the lower seam at an interval computed as 43 feet. This coal seam may correspond to the lowest thick seam of the middle coal group as exposed at the mouth of Wolf Creek. This correlation is suggested by the similarity in details of its measurements and by its position near the base of the group of coals. Two samples for analysis were taken at these openings (see analyses E and G, p. 84).

As is explained later in the discussion of the analyses, one of the openings on this seam shows coal which is a high grade of anthracite, so far as its percentages of fixed carbon and volatile matter are concerned, but which contains such a high percentage of ash that its commercial value is materially impaired. On the other hand, the 
sample from an opening on the same seam only 40 rods distant shows that the coal should be properly classed as bituminous of good quality, but in no sense an anthracite.

A smaller seam measuring about 28 inches in thickness has been opened in a number of places a short distance beneath the large seam. just described. Reports of analyses of this coal (not made by the United States Geological Survey) indicate an anthracite of excellent quality, containing only a normal percentage of ash. No statement can be made as to the extent of this smaller seam.

An entry 300 yards farther west; also near the public road, is on a seam about 150 feet stratigraphically higher than the thick seam. described above. This seam measures 6 feet 2 inches, without parting, at the face of a 140-foot drift. On account of its stratigraphic position it may be supposed to represent the Wadge seam, though it is recognized that such correlations are very uncertain. A sample for analysis was taken at the opening and shows a composition very similar to that of the Wadge bank.

Morgan tract.- To the south and east of the gap east of the Crawford mines through which the road passes, and near this road, are a number of openings on coal seams that are referred to the middle group. These were all so badly fallen in that the coals were not measured. These seams are thought to be of the same group and probably to represent the same beds as those opened on the Crawford tract. Although they were not traced through continuously from one locality to the other, the strike of the strata, where it could be determined, was found to be slightly east of south from the Crawford openings toward the Morgan property, which would bring the seams of the two properties at practically the same stratigraphic horizon. This conclusion is further borne out by a conformable structure found in the Twentymile sandstone and associated strata west of these properties.

An entry on this tract near the county road was reported to have opened a thick seam of coal with a high percentage of ash, and it is possible that this may be the same seam as the thicker one opened on the Crawford property, which also carries considerable ash, as shown by the analyses. This correlation is, however, little more than a guess. At this point a lava sheet is plainly exposed, overlying this seam at an interval of perhaps 30 feet (this distance was not measured). The coal is said not to have shown any effect whatever from the proximity of this igneous sheet. From this mine toward the south, up the open valley that heads back between the two peaks of Wolf Mountain, this same seam, or perhaps other coals near the same horizion, are exposed on the creek bank and in some prospect pits. The lava sheet is also traceable in this direction, and at one point was found to have anthracized the coal. It is 
thought that the middle coal group, to which these coals belong, is probably interrupted by the igneous mass of Wolf Mountain, but this interruption is more in the nature of a simple break, with very little dislocation or tilting, as the rocks of the same coal group are found again on the south side of the mountain, lying as though they might have passed under the mountain in an uninterrupted course.

School-section mine.-On the school section, just east of the property described above, there is a seam that has been mined by the settlers of Deep Creek, and judging from the size of the dump heap, a considerable quantity of coal has been taken out. The mine is visible from the public road, on the face of a steep ridge and a little over 300 feet above the road. The opening showed about 8 feet of solid coal, but the seam could not be measured exactly, as the lower part of the coal was standing in water. The rocks at this point dip about $10^{\circ} \mathrm{W}$. Without doubt this is a seam of the lower group of eoals. By a calculation in which its dip, its elevation, and its distance from the seams of the Morgan and Crawford properties are taken into account, it is apparent that it would pass at least 600 feet bèlow those of the middle group on the Crawford tract. By tracing the sandstone hogbacks from the base of the series on Deep Creek up to this coal we find it to occupy approximately the position in which the lower coal would be expected.

Mitler and tributary gulches.-Miller Gulch is the upper valley of a headwater tributary of Deep Creek north of the school section just mentioned. A large number of openings have been made on coal outcrops about the head of this gulch, and these seams are also almost certainly of the lower coal group. Prominent among these is the Keitel mine, near the head of Miller Gulch. This consists of a tunnel which has been driven 50 feet on a 49-inch seam of good bright coal, in which no partings were found. The immediate roof is of bony coal and shale, and the dip of the bed is $4^{\circ}$ in a westerly direction. Sample H (p. 84) was taken from this mine. A 2-foot seam underlies the Keitel seam by about 9 feet. The group is apparently continuous along the eastern face of Pilot Knob Ridge, and includes the Ducey seam, as well as exposures north of Ducey tunnel.

The Ducey tunnel is an old opening located on the eastern side of Pilot Knob. It has been worked for about nine years to supply the settlers on the head of Deep Creek and coal has been hauled from this bank, for domestic use, as far as Hahns Peak. The old tunnel showed 5 feet of solid coal, which is described as block coal owing to its manner of breaking out in large cubical joint blocks. This seam has a light dip to the west. The coal does not appear to have been affected by its proximity to the huge basalt mass of Pilot Knob. A seam having a 
thickness of 5 feet 2 inches has recently been opened 50 feet above the old tunnel. Many other seams above and below are indicated by smut and small outcrops along the face of the hill.

Shelton tract.-About 3 miles northeast of Pilot Knob a thick sheet of basalt, known as the "rim-rock," is exposed, lying in a nearly horizontal position just below or within the lower coal group. The property known as the Shelton tract overlies this intruded sheet. Coal seams of this tract have been extensively and very systematically prospected by means of pits, drifts, and bore holes, and anthracite is reported to have been found over most of the field that lies directly above this basalt sheet. The outcropping rim of the sheet is continuous for a number of miles to the north, and it appears to follow approximately the same stratigraphic horizon throughout its known extent. Its effect on the overlying coal seams may therefore have been somewhat uniform over a very considerable area.

Mr. Shelton kindly permitted the examination of the original records of the bore holes that were put down on this property and of a number of samples of the coal obtained from the holes. Several holes were sunk 200 to 250 feet, showing 12 , or possibly more, coal seams in a vertical interval of 200 feet. Of these a single seam, averaging about 6 feet in thickness, appears in nearly all the holes. This is always bituminous where found and is 150 to 175 feet above the upper surface of the basalt.

Sixty to 80 feet below this seam is another which appears to be much more variable in character, being broken up by local partings of variable thickness and number and being recorded as anthracite, semianthracite, and bituminous in the different holes. It is 6 feet 3 inches thick at the only place where it was not found broken up by partings.

This seam fixes the upper limit of anthracization for this district at a distance of about 70 feet above the igneous sheet. The line drawn between bituminous and anthracite was of course that fixed by the drillers and was based upon the physical appearance of the coal. It is to be doubted, therefore, whether the coals recorded as anthracites would all be termed such on chemical examination. However; this record is of value to the extent that it establishes a somewhat definite distance from the basalt sheet beyond which no recognizable alteration has been produced.

A considerable number of seams, of thicknesses varying from 2 to 4 feet, are also shown, and some of these are doubtless first-class anthracite. The thicker seams, as well as some of the smaller ones, are exposed at their outcrops in a number of surface pits and short drifts. Measurements taken by members of the party at these surface exposures serve to corroborate the measurements given in the test-hole 
records. At one locality the two thicker seams were found, the one about 75 feet above the otner, although at that place only the upper seam could be measured accurately.

The basalt sheet itself was roughly estimated to be at least 75 feet thick. It shows some tendency to columnar jointing, the blocks standing approximately vertical. In composition it is similar to the rock of Pilot Knob.

Slopes of Sand Mountain.-The outcrop of the coal-bearing rocks continues, in part at least, from the Shelton tract north to the eastern edge of California Park, where these strata are found tilted against the slopes of Sand Mountain. Little is known concerning this extremity of the field, for much of the ground is covered by débris of igneous rocks. Coal was found outcropping on the sides of the east fork of Elkhead Creek in the sandstone ledges through which the creek cuts its way before entering the open valley of the park. The rocks dip to the west at angles ranging from $25^{\circ}$ to $35^{\circ}$. The sandstone ledges of the lower coal group were seen extending toward the north and apparently disappearing under the talus of igneous rock from Sand Mountain. Looking from the direction of Hahns Peak, Sand Mountain is apparently capped by igneous sheets, lying beneath which are sandy strata, possibly a portion of the lower barren sandstone series. It is from this great scar on its eastern face that the mountain takes its name.

Area of anthracite field:-The total field within which the three coal groups of the Mesaverde formation are known to have been locally affected by heat from the intrusion of molten lava may be included within a single tract of some 25 square miles. The actual area in which anthracite coal is now known to outcrop or within which it is thought likely to be found does not exceed 10 square miles, as a considerable portion of the total tract mentioned above is occupied by the basalt. The field is clearly defined on the east by the hogback ledges of the lower barren sandstones, beyond which only rocks older than the coal strata are found. The coal seams dip west from their outcrop, varying from a few degrees near the eastern edge of the field to $20^{\circ}$ or more on the west, forming a belt about 2 miles wide. This carries the coal seams to an undetermined depth beneath the prairie in the upper valleys of Morgan and Elkhead creeks and leaves the western margin of the available coals an uncertain problem. The estimate does not include the Quaker Mountain district, whose coal seams are considered to be of later or Laramie age, and, in most cases, of quality inferior to that of the older seams of the field, although, as explained in a later paragraph (p. 77), some of these Laramie coals have been locally altered to anthracite. 


\section{ELKHEAD AND QUAKER MOUNTAIN DISTRICT.}

\section{GENERAL DESCRIPTION.}

The fourth main structural division of the Yampa field is occupied by younger rocks, which lie in the trough of the major synclinal basin of the field. These rocks have been described under the heading of Laramie formation (see p. 29). Their distribution and extent are represented by coloring on the topographic map ( $\mathrm{Pl}$. I, pocket).

As in the preceding descriptions, this structural division is further divided into districts named for the localities at which their coals are now exposed or developed. Since the coals which these beds contain are considered of less importance than those of the rest of the field, and since they have not been developed to any considerable extent, less attention was paid to this portion of the field during the present investigation. Such localities as were visited may be included under the following district names:

1. Hayden openings.

2. California Park.

3. "The Potholes" on Elkhead Creek.

4. Quaker Mountain.

5. Mouth of Elkhead Creek.

6. Fortification Creek.

Many seams of coal are contained in the Laramie formation and at a number of places were found to be of considerable thickness. The coal is locally spoken of as lignite in distinction from the bituminous and anthracite of the rest of the field, but it should be called subbituminous, as lignite is reserved for the brown woody coals of North Dakota and Texas. No samples were obtained from any of the seams of this group, and an estimate of its quality can only be based on its physical appearance and on reports of its behavior, as, for example, its ready slacking when exposed to the air. It is commonly conceded by the settlers of the district to be inferior in quality to the older bituminous coals of the main Yampa field. Few prospects were found on seams of this coal, and in the majority of those found only weathered coal was exposed. The coal is of comparatively light weight, noticeably so when taken in the hand; it readily crumbles to a brown powder in digging from a bank; and where observed it contains much fossil resin. At places, however, it showed on fresh fracture a pitchy-black luster, and was so tenacious as to be very hard to pick out with the hammer.

\section{COAL BEDS.}

Hayden openings.-A mile or more northwest of Hayden a number of Laramie coal seams show in the face of the bluff on the north side of the river. One of these when dug out showed a seam about 5 
feet in thickness of bright-black coal, seemingly of light weight. This coal contained much fossil resin. The beds in which it is found are for the most part poorly consolidated sands, light in color, with occasional (concretionary?) beds of hard sandstone.

On the south-facing slope of this same escarpment, about onefourth mile to the southeast, toward Hayden, is an old entry on what is probably the same seam. The opening had completely fallen in, but the seam must be at least 5 feet thick. Burned streaks above and below this opening indicate the presence of other seams.

Directly north of Hayden the Laramie escarpment rises 1,000 feet above the level of the river. At its very base is exposed the soft black Lewis shale, which occupies the entire interval between these Laramie beds and the Mesaverde coals. The major part of the bluff is composed of alternating sands and clays, with occasional harder sandstone layers and coal seams. On one of the spurs leading south from this summit indications of coal were noted at 20 different horizons.

California Park.-With the exception of its easternmost headwaters, Elkhead Creek flows throughout almost its entire course upon the outcrop of the Laramie formation. In California Park coal is found outcropping in many places. A few seams were found in the northern part, not far from the foot of Saddle Mountain. One of these seams measured at least 3 feet in natural exposure and was doubtless thicker. This coal had been exposed for an indefinite period in the creek bank and was still pitchy black and apparently fresh with a little digging. It seems of light weight and is brown when powdered, but is very solid in the bank. It is associated with blue clay shale and white unconsolidated sandy beds, with occasionally a harder sandy layer. Numerous other smaller coal seams occur near by.

Southeast of Gantt's ranch, in California Park, a number of exposures showing coal and beds of loose sandy and clayey strata were found on the slopes of Quaker Mountain. Such of these as were examined were not thought to be of much importance. The slopes of Quaker Mountain are made up of successions of flat benches and steeper pitches, most of which are covered by-a dense growth of quaking aspen and in some parts by spruce timber. As in other parts of the field, the spruce is usually found in the vicinity of igneous rock, while the quaking aspens cover the sandy and shaly slopes. The igneous rock is usually found at or near the summits of the ridges, seemingly having formed the "backbone" that has protected the surrounding softer rocks from erosion. The steps or benches that form the slopes are doubtless in most cases the result of land slips. In many places these benches are tipped up at their outer edge, and the basins thus formed may contain ponds. 
At the southeastern end of California Park, below Gantt's ranch, and a mile or more above Elkhead Canyon, are numerous openings showing one or more thick seams of coal. Taken in rude order from east to west these openings expose seams having nesses: Six feet 6 inches, 4 feet 2 inches, 5 feet: 6 inches, 7 feet, 7 feet 7 inches, 6 feet 5 inches, and 7 feet 1 inch. In most of these cases the full thickness of the seam was not exposed or the covering was so thin that the seam had wasted at the top. In all cases where there was a sufficient cover the coal appeared to be of good quality and almost free from partings.

At the point called Diamond Drill hill, where Elkhead Creek enters its canyon, large dump heaps showed that much work had been done in two old entries near the creek. These openings have so fallen in that measurements are impossible.

Most of the above exposures show a westerly dip of about $10^{\circ}$. The several openings showing a thickness of approximately 7 feet of coal may all be upon the same seam, although the cover of vegetation and soil and the frequent landslips would not permit tracing a seam continuously from point to point.

"The Potholes," on Elkhead Creek.-The open valley of California Park owes its existence to hard sheets of igneous rock which cross Elkhead Creek west of Quaker :Mountain.: While the stream was slowly cutting down its channel through these rocks, its headwaters, which were in the meantime working on the soft Lewis shale and Laramie formation, were able to denude the large area known as California Park. The creek has now sunk its canyon entirely through and at places several hundred feet below the volcanic sheet, which offered the greatest resistance. The outcrop of this huge lenticular mass may now be seen as a prominent cliff, surmounting for 2 miles the west wall of Elkhead Canyon, which leads down from California Park to another small park locally known as "The Potholes."

A portion of what was originally the same sheet lies exposed on the east side of the valley, rising against the flank of Quaker Mountain. This mass dips $8^{\circ}$. westerly, conformably with the sediments. The rock has a coarsely speckled appearance, brought out more conspicuously in its prevailingly much-weathered condition, but is a basalt or diabase in composition. A good exposure of the sediments underlying this intrusion is shown in the creek bed, and the following section was recorded at this point (Pl. IX, $A$, p. 66):

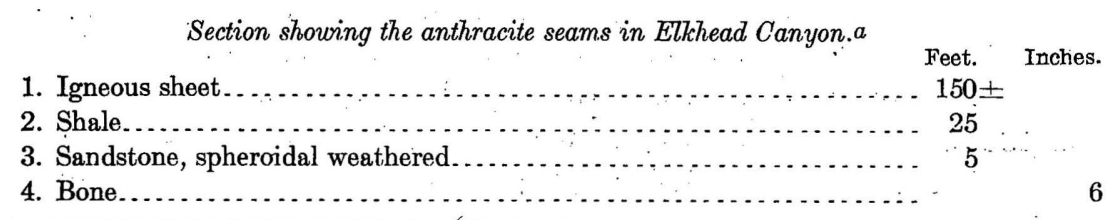

a Thicknesses, except coals, are estimated. 
5. Coal, anthracite $\quad$ Feet. Inches.

6. Shale, bone and black...

7. Dark shale and bone................... 5

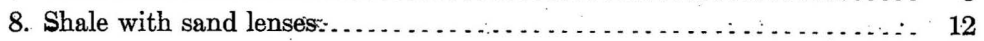

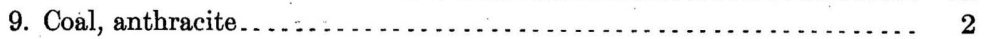

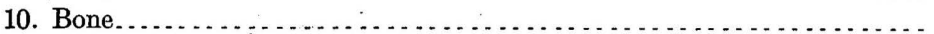

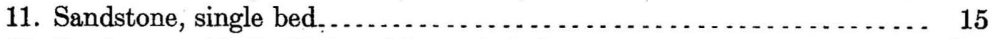

12. Sandstone, thin-bedded and burned shale $\ldots \ldots \ldots \ldots \ldots \ldots \ldots \ldots \ldots \ldots$

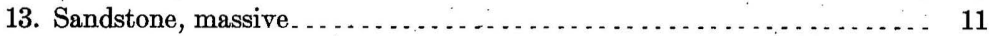

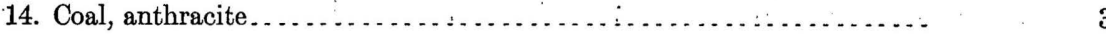

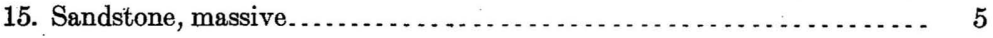

This is an instance in which the coals have been baked by an igneous sheet lying above, The main seam of anthracite is black, lustrous, and clear, but the coal itself is badly broken by little faults or slip. joints. This seam lies about 50 feet below the base of the huge igneous mass, and a small seam lies some 30 feet lower. The shale and sandstone, as well as the coals, are thoroughly baked. A few fossils were found in them, including a Unio and many broken stems of plants that were unrecognizable. The sediments are classed as Laramie. No analysis was made of this coal and no statement can be made of its quality, except that it seems to be undoubtedly anthracite.

Quaker Mountain.-Recent prospecting has been carried on at the southwestern end of Quaker Mountain under the direction of Mr.W. L. Jameson, of Denver. A considerable number of openings in this locality were found exposing coal averaging 4 feet in thickness. This coal is evidently a part of the series of sediments classed as Laramie and is not far from the huge vertical basalt dike that forms this end of Quaker Mountain. None of the openings visited penetrated beyond the weathered outcrop.

At the eastern end of Quaker Mountain, near the gap through which the road from Pilot Knob to California Park crosses, two drifts have been driven by the Egeria Coal Company. Several seams show at that place, outcropping on the northern slope of Quaker Mountain, and the following section was measured:

Section at Egeria Coal Company's prospects on Quaker Mountain.

1. Shale, clay.

Feet. Inches.

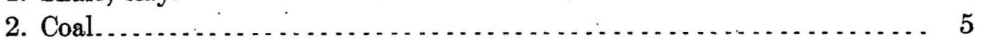

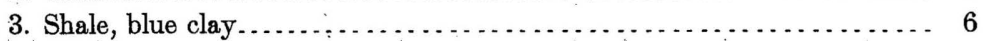

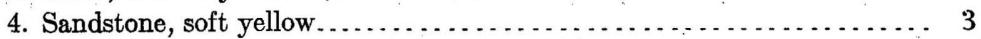

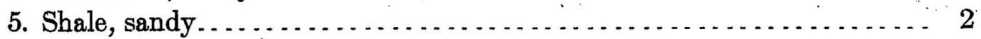

6. Sandstone, bedded yellow ...... $\ldots \ldots \ldots \ldots \ldots$

7. Shale, blue drab clay. . . . . . . . . . $\ldots \ldots \ldots \ldots$

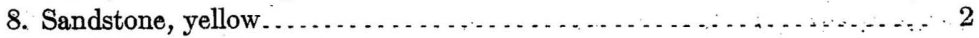

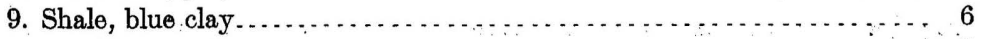

10. Sandstone, yellow..............

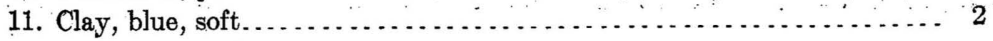


Feet. Inches.

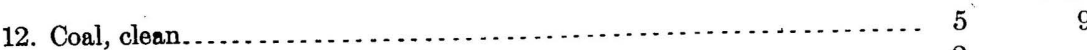

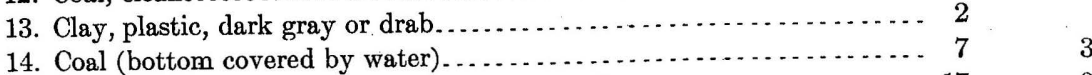

15. Sandstone, massive, white, cross-bedded, single stratum $\ldots \ldots \ldots \ldots \ldots \ldots$

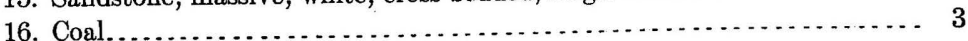

17. Clay floor.

One entry had been driven in about 60 feet on the lower bench of the thick seam (No. 14 in section above). The coal that had been taken out was much weathered. The entry ran in toward the north or northeast, on the dip of the seam, which is very slight, being only about $1^{\circ}$. The openings were very wet and were surrounded by heavy timber.

These seams have been provisionally classed as Laramie and are shown as such on the map, although considerable uncertainty is felt in defining the exact limits of this and other formations in this vicinity. The extension of the upper coal group of the Mesaverde was not.found north of Pilot Knob, and there is a possibility that the coal in the Egeria Company's tunnel may be a part of the upper group of the older coal series. The balance of evidence seems, however, to favor the supposition that these coals are part of the Laramie formation. The beds lie nearly horizontal, apparently conformably overlying the Lewis shale in California Park to the north. In character they resemble the Laramie strata observed in other parts of the field, consisising of soft white sandy and plastic blue and drab clay beds rather than the harder sandy beds of the Mesaverde. Between Quaker Mountain and the known Mesaverde coals north of Pilot Knob and the Shelton tract the structure and position of the formations are obscured by the basalt talus and a heavy cover of timber.

Mouth of Elkhead Creek.-Coal smut indicating probable seams was noted in the Laramie sediments forming the banks of Elkhead Creek near its mouth. Apparently these indications correspond in position to the seams north of Hayden.

Fortification Creek.-Indication of coal smut and small coal seams were noted along the stage road that runs north from Craig, a number of these being but a short distance from Craig. It seems likely that the seams of the Kimberly and Walker banks already described on page 62 should be classed with these, although they are not so represented on the map (Pl. I).

On Dry Fork of Little Bear Creek, which is tributary to Fortification Creek, a coal bank known as the Seymour mine has been opened and worked for domestic supply. This is undoubtedly one of the Laramie coals. The seam, measuring 17 feet in thickness, is exposed for a distance of 150 feet in nearly horizontal position in the creek bank near by. The roof is a compact blue.clay, well exposed for a thickness of 6 feet. The coal of this seam is solid, black, and bright, 
but seems to be lighter weight than coal from the older formations of the field. No sample was obtained for analysis, but an analysis is given in the volume of Mineral Resources for 1892 and is described on page 86 . On this same seam are many prospect holes within a distance of some 3 miles along Dry Fork. Some prospects also have apparently revealed lower seams of considerable thickness, the coal in all cases being similar in appearance to that of Little Bear Creek. One prospect 2 miles northeast of the Seymour mine exposed the following section:

Measurement at prospect 2 miles northeast of Seymour mine.

Feet.

Coal (top of seam not found)

4

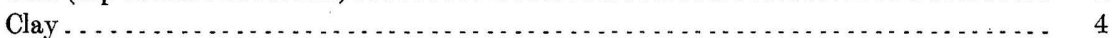

Coal . . . . .

It is probable that the coal here shown belongs to a lower seam than the Seymour, but the data do not admit of certainty on this point.

\section{PETROLEUM.}

The presence of oil has been suspected in various parts of the area covered by this report, notably near Pool post-office, in the prairie southwest of Hayden, and in the valley of Yampa River south of Lay post-office.

\section{VICINITY OF POOL.}

\section{OIL SPRINGS.}

The chief indication of oil near Pool consists of a well-known seepage or "oil spring" in the canyon of Tow Creek 3 or 4 miles north of the stage road which follows Yampa River. The oil from this spring is in constant use as a lubricant and is regularly gathered by ranchmen and coal miners. It issues from the rock in globules with the water of the spring and when allowed to accumulate for some hours is found as a sheet on the surface of the small pool of water. This sheet may attain a thickness of one-eighth of an inch. It is readily freed from the water by use of a small, smooth board whose flat side is. pressed into the film; when the board is lifted the oil adheres to it and may be scraped off upon the edge of a bucket. When the spring is kept clean, the daily flow of oil is approximately 1 bucketfull. The oil is black and heavy and has an agreeable odor.

This and other similar though smaller seepages in Tow Canyon have a remarkable fascination for cattle. The large spring is protected by a strong fence, but the others are so trampled by cattle that they could not be studied. It is a popular impression that the cattle are attracted by the oil, but it is more probable that the waters are slightly salt and that the behavior of the cattle is thus explained. At Lay, in dry seasons following wet ones, there occurs in spots a white incrustation which is sometimes largely common salt. 
WELLS.

Four wells have been drilled within a radius of 4 miles from Pool. One of these is in Tow Canyon about 2 miles north of the stage road. It is said to be 625 feet deep and is abandoned. It is not known what the well showed. Its entire depth must be within the barren sandstones and shale below the lower coal group. Less than 2 miles east of Tow Canyon is Clarke Canyon. In this valley, about 1 mile north of the stage road, the so-called Stuckey well was drilled to a depth of 1,100 or 1,200 feet. Artesian water was struck and still continues to flow at a slow rate. The horizon of the mouth of this well is within the lower coal group, and there is every reason to believe that the rocks traversed are similar to those of the section on page 23. Opposite the mouth of this canyon on the Milner ranch south of the stage road a well was drilled in the winter of 1901-2 to a depth of about 700 feet. It is said that small quantities of oil were brought up by the bailer, but the well was abandoned: The mouth of this well is a few hundred feet above the Trout Creek sandstone. In the year 1901 a company, of which Mr. N. P. Hill, of Denver, was the head, drilled a well on the west bank of Elk River north of the stage road from Trull postoffice to Steamboat Springs. This well is probably about 1,500 feet deep, but no data concerning it are given out. The fact that the derrick and machinery are still on the ground (August, 1905) and that a keeper is employed to reside on the property has given to some the impression that encouraging prospects were encountered. The well is located on the Mancos shale underlying the Mesaverde, and most of the drilling must have been in this formation, but the Niobrara may have been reached.

\section{STRUCTURE.}

It will be observed that the seepages noted are almost on the axis of the Tow Creek anticline (p. 14). The eastward dip from this axis is locally as high as $45^{\circ}$ (as in the vicinity of the first oil well named), the westward dip usually being less than one-third that amount. While in general an anticlinal structure is favorable to the concentration of oil when present, it is probable that a fold so sharp as this would involve such a fracturing of the overlying rocks as to allow the oil to escape. In such a case the abundance of surface indications may indicate a leaky condition of the reservoir rather than a large accumulation of oil. If oil in commercial quantities is to be found in this region, it will probably be in subordinate folds instead of along the axes of these mountain-making anticlines. The age of all these rocks in which oil has been sought is approximately that of the rocks in the oil fields at Florence and Boulder. 


\section{VICINITY OF HAYDEN.}

A single well in the prairie west of the Sage Creek anticline and some 8 miles southwest of Hayden was drilled to a depth of 1,000 feet or more. It is not known to have pierced anything but alluvial material and the Lewis shale overlying the coal-bearing rocks. No oil is known to have been encountered. The indications leading to the drilling of this well are not known. The structure is that of a wide open syncline.

\section{VICINITY OF LAY.}

The valley of Yampa River south of Lay is cut in the dark Mancos shale underlying the Mesaverde. Locally these are frequently spoken of as the "oil shales." There has been no development, but it is said that in an excavation at the " 555 ranch," some 8 miles south of Lay, a hole drilled for a shot was allowed to stand and was later found to be filled with oil, on the withdrawal of which a constant seepage of oil into the hole was observed. The horizon of this occurrence is near the top of the Mancos shale.

On Lay Creek, one-half mile south of the post-office, there is a somewhat abundant seepage of gas, apparently in large part $\mathrm{SO}_{2}$. The gas bubbles up freely through the water, burns readily, and has a. distinct odor.

Bull. 297-06-6 


\title{
CHARACTER AND USE OF THE YAMPA COALS.
}

\author{
By Marius R. Campbell.
}

\section{CHEMICAL COMPOSITION.}

Like most of the coal fields of Colorado, the Yampa field contains a variety of coals ranging from so-called "lignite" or "black lignite" to anthracite. In general the former is found where the rocks are little disturbed and at a considerable distance from the great mountainous centers of uplift. The bituminous coal usually occurs in those parts of the fields that are near the bases of the mountains, and the anthracite (which is the product of local metamorphism) where some dike or sill of igneous rock has cut the coal or come into sufficiently close proximity to drive off its volatile constituents.

During the present survey it was found that the main body of the Yampa field contains only bituminous and higher grades of coal that occur in the Mesaverde formation, while the so-called "lignites" are restricted to the Laramie formation in the region northwest of Craig. and Hayden.

The bulk of the coal examined is bituminous, having a black, shining luster and more or less prismatic structure. The coal is sufficiently hard to be mined without a heavy percentage of slack and also to stand transportation. It does not weather badly, and so is well fitted for dontestic use and for the production of steam. In order to determine the chemical composition of the coals, 16 samples were taken during the progress of the present survey and later were analyzed at the chemical laboratory of the United States Geological Survey coal-testing plant, St. Louis, Mo.

In determining the value of a coal from its chemiçal analysis, and also in comparing one analysis with another, it is important to know how the sample was taken, how it was treated after it was obtained, and how the analysis was made, especially the determination of moisture.

In this work the samples were all collected and treated according to the following methods of sampling adopted by the United States Geological Survey coal-testing plant: ${ }^{a}$

a Bull. U. S. Geol. Survey No. 261, pp. 19-20; and Prof. Paper U. S. Geol. Survey No. 48, pt. 1, p. 33. 
After the face of the coal was cleaned of weathered coal and powder smoke a cut was made across the face of the bed from roof to floor, including all of the benches of coal mined and such impurities as were not removed in ordinary work. This cut was about 3 inches wide and 1 inch deep; the coal obtained from it, amounting to 25 or 30 pounds, was caught upon an oilcloth blanket spread upon the floor of the mine so as to protect the sample from water and from admixture of shale and clay fragments that usually abound in such places.

The coal composing the sample was then pulverized and quartered down, according to the generally accepted rules for preparing samples, until a quart sample was obtained, the particles of coal being reduced to a size not much greater than one-half inch in diameter. The sample was placed in an air-tight galvanized iron can, having a screw top, and the can was hermetically sealed by screwing the top down tight and covering the joint with adhesive tape. The can containing the sample was then mailed to the testing plant. When it reached the chemical laboratory, the sample was at once transferred to a glass jar, in which it was sealed until the time arrived for making a chemical analysis.

By being sealed at the mine the sample reached the chemical laboratory with its moisture content unchanged. Part of this moisture is inherent in the coal and part is extraneous, either derived from water in the mine or from the atmosphere. In order to eliminate some of the extraneous moisture the samples, during the first year's work at the testing plant, were exposed to the air after they were pulverized until they reached a fair degree of constancy of weight and then were analyzed. The amount lost during the exposure to the air is noted in the report as "loss of moisture on air drying." This method, however, was found to be unsatisfactory, since the amount of loss depended almost entirely upon the degree of saturation of the air, and this varied greatly from day to day.

During the second year, when the samples from the Yampa field were analyzed, the method was changed, the samples being artificially dried in order to secure greater uniformity of the moisture content, the method being as follows: ${ }^{a}$

In order to make determinations of the loosely held moisture more uniform and definite, a special drying oven has been designed and introduced into the laboratory. In this oven samples of several pounds weight can be dried in a gentle current of air, raised from $10^{\circ}$ to $20^{\circ}$ above the temperature of the laboratory. In this way the coal is air-dried in an atmosphere with a very low dew-point and not subject to large percentage variations, and the results obtained were considerably more concordant.

The proximate or ordinary analyses of the samples collected in the Yampa field are given in the following table, which contains the analyses of the samples as received (that is, as they came from the mine), and also the analyses of the same samples after air drying, so that either can be used without recalculation: 


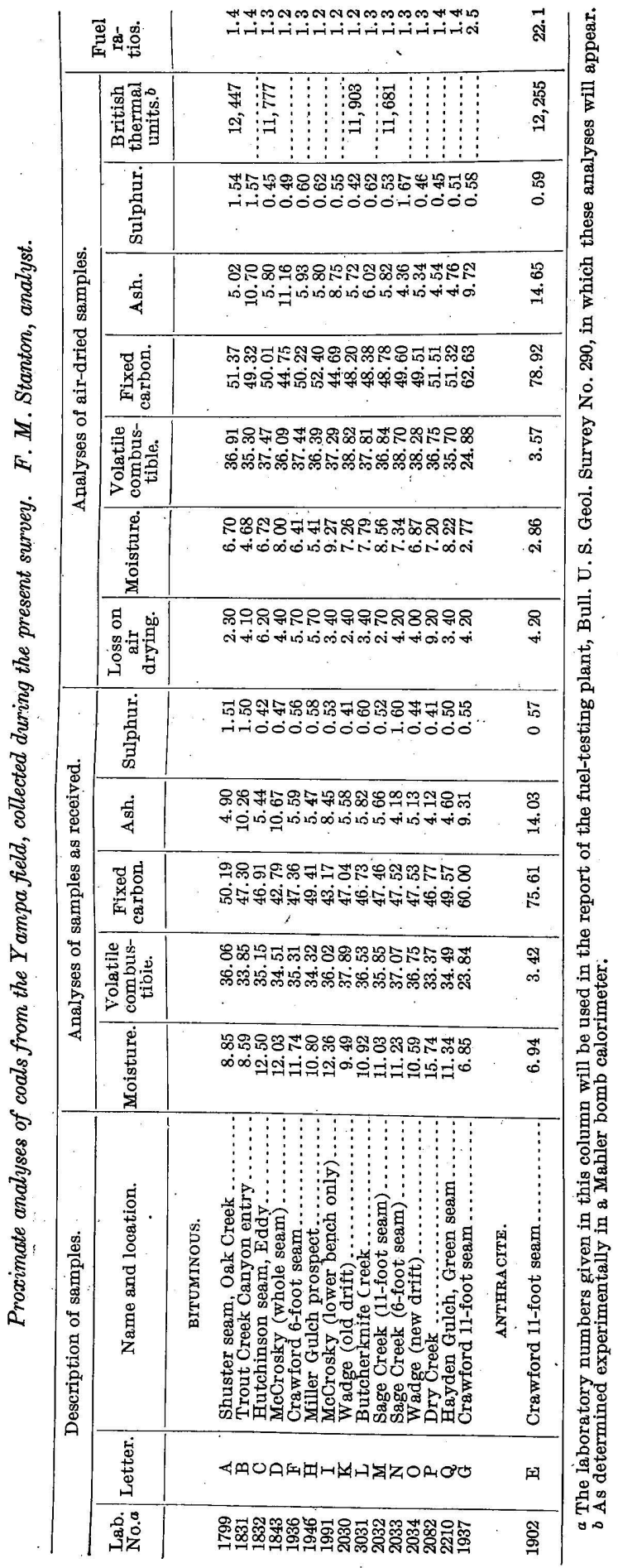


Utimate analyses af air-dried samples of coals from the Yampa field, collected during the present survey. F.M. Stanton, analyst.

\begin{tabular}{|c|c|c|c|}
\hline . & $\begin{array}{l}\text { Sample A, } \\
\text { No. } 1799 .\end{array}$ & \begin{tabular}{|l} 
Sample C, \\
No. 1832.
\end{tabular} & $\begin{array}{l}\text { Sample E, } \\
\text { No. 1902. }\end{array}$ \\
\hline 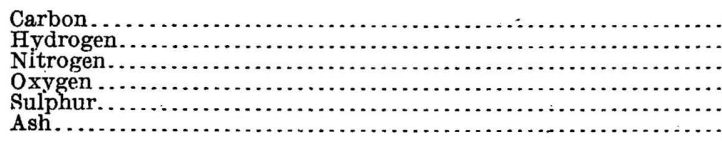 & $\begin{array}{r}70.20 \\
5.57 \\
1.58 \\
16.09 \\
1.54 \\
5.02\end{array}$ & $\begin{array}{r}67.43 \\
5.48 \\
1.52 \\
19.32 \\
0.45 \\
5.80\end{array}$ & $\begin{array}{r}76.62 \\
2.50 \\
11.35 \\
4.29 \\
0.59 \\
14.65\end{array}$ \\
\hline Carbon-hydrogen ratio...$\ldots \ldots \ldots$ & $\begin{array}{l}100.00 \\
12.6\end{array}$ & $\begin{array}{l}100.00 \\
12.3\end{array}$ & $\begin{array}{l}100.60 \\
30.6\end{array}$ \\
\hline
\end{tabular}

Mr. R. C. Hills, of Denver, who for a long time was geologist for the Colorado Fuel and Iron Company, examined this field many years ago, and in Mineral Resources for 1892 published an account of his explorations, and included therein the analyses of nine samples of coal (p. 86). Unfortunately, the exact localities from which the samples were obtained are not given. Analyses Nos. 1 and 2 doubtless correspond to analysis $\mathrm{E}$ of the preceding table and Nos. 3 and 4 to analysis $\mathrm{F}$ (p. 84). Analysis No. 6 was doubtless made from a sample from some of the numerous openings on the Shuster seam on Oak Creek, and therefore is the same as analysis $\mathrm{A}$. The other analyses given by Mr. Hills are from different localities from those sampled during the present survey, and No. 9 is from a different group of coals - the Laramie. This coal is distinctly below the grade of bituminous, but its place in the scale will be discussed on another page.

Another unfortunate feature and one which detracts greatly from the value of Mr. Hills's analyses is the fact that no mention is made of the method of sampling nor of the care of the sample after it was taken. In most cases the results are so similar to those obtained during the present work that it seems probable the same method of sampling was used, but in certain cases, like No. 6, the ash, which is given as 1.35 per cent, is so low that it is obvious that only selected or lump coal was taken as a sample. As shown on page 84, the ash in the best coal on Oak Creek runs 5.02 per cent in the mine sample. Therefore the publication of an analysis showing it as only 1.35 per cent is, to say the least, misleading.

In using these analyses it must be remembered that probably no provision was made to preserve the moisture content unchanged. In the semiarid climate of Colorado it is probable that coal samples would dry out in transit and that when analyzed their moisture content would be decidedly less than when taken. In other words, the sample when analyzed would probably correspond very closely with the air-dried samples described in this report.

The table following contains both proximate and ultimate analyses of the samples taken by Mr. Hills as published in Mineral Resources for 1892, page 365 . 


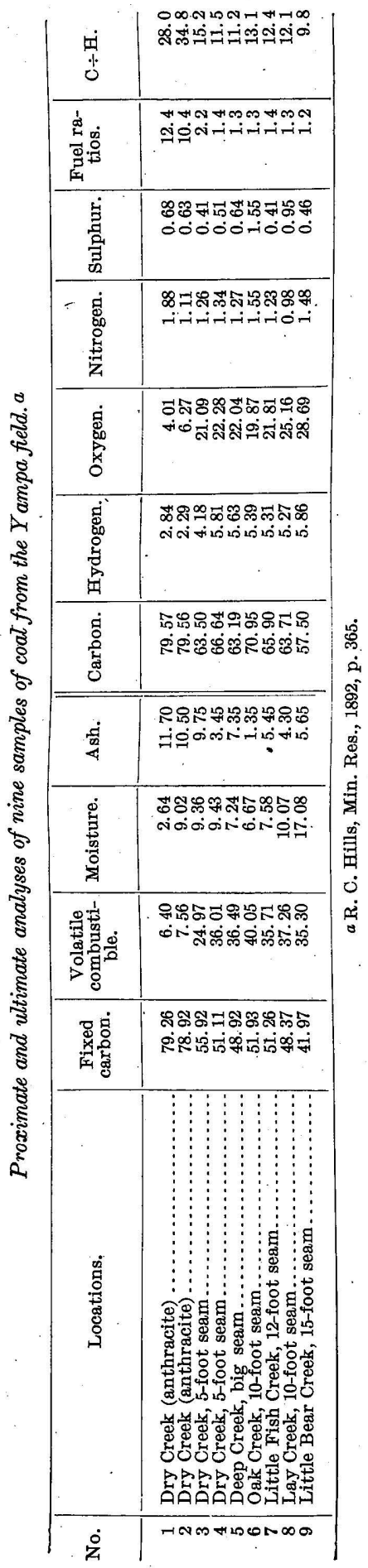




\section{CLASSIFICATION.}

Before attempting to analyze the above results, it is necessary to state briefly the present condition of coal classification.

At the present time there are recognized commercially six great groups of coal. Those which belong to the bituminous and higher classes are quite well defined and understood, but those which belong below the grade of bituminous are recognized only in a broad way, and considerable confusion exists in the commercial world regarding the names to be applied to them. In order to help clear up this confusion the United States Geological Survey recently has adopted names for the two lower classes of coal as follows: "Subbituminous" for the great class below bituminous that heretofore has been called "lignite" or "black lignite;" and "lignite" for the lowest grade of brown woody coals of North Dakota and Texas. The great groups referred to above are, therefore:

1. Anthracite.

2. Semianthracite.

3. Semibituminous.

4. Bituminous.

5. Subbituminous.

6. Lignite.

Anthracite, semianthracite, and semibituminous coals are generally classified according to their fuel ratios, which is understood to be the fixed carbon divided by the volatile combustible matter. In the original Pennsylvania classification proposed by Persifor Frazer, jr., ${ }^{a}$ the fuel ratios are as follows:

Pennsylvania classification.

Fuel ratios.

Anthracite 100 to 12

Semianthracite. 12 to 8

Semibituminous .................................................... 8 to 5

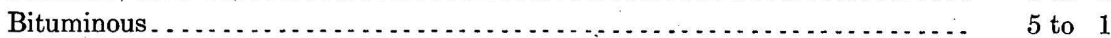

Since this was proposed there has been a constant tendency toward the reduction of the limits of the various groups, and now in the trade it is generally understood that anthracite and semianthracite run from an indefinite upper limit to 5 , and semibituminous from 5 to $3{ }^{b}$

If a fuel ratio of 3 is considered to be the upper limit of the bituminous group of coals, it will be seen that only one of the Yampa coals that have been analyzed belongs in a higher group. This is the Crawford coal with a fuel ratio of 22.1, as shown in the table on page 84 , and what is supposed to be the same coal with fuel ratios of 12.4

a Trans. Amer. Inst. Min. Engrs., vol. 6, p. 430; also Rept. MM, Second Geol. Survey of Pa. $\checkmark$ Coals of Maryland: Maryland Geol. Survey, vol. 5, p. 239. 
and 10.4 in the table on page 86. By all criteria this would be classed as an anthracite coal. When compared with standard Pennsylvania anthracites, it is found to have about the same composition. Thus the average of 44 analyses of anthracites from Carbon, Luzerne, and Schuylkill counties, as published in the reports of the Second Geological Survey of Pennsylvania, gives a fuel ratio of 22.1, exactly the same as the Crawford anthracite. In comparing Colorado with Pennsylvania anthracites, however, it must be borne in mind that the latter do not average more than 5 per cent ash, while the former generally carry a large amount-in this particular case 14.65 per cent. This does not affect the theoretical standing of the Yampa anthracite, but it will have a decided effect upon its market value.

The other samples range in fuel ratios from 2.5 to 1.2. Those standing at or above 2 are undoubtedly bituminous, but when the fuel ratio falls below 2 it is not reliable, as some of the lignites of North Dakota show a fuel ratio as high as some of the best Pittsburg coal.

Recently a new classification has been proposed by the writer, ${ }^{a}$ based on carbon-hydrogen ratios obtained in ultimate analyses of air-dried samples. Briefly stated, this classification is as follows:

Proposed groups of coal and allied substances.

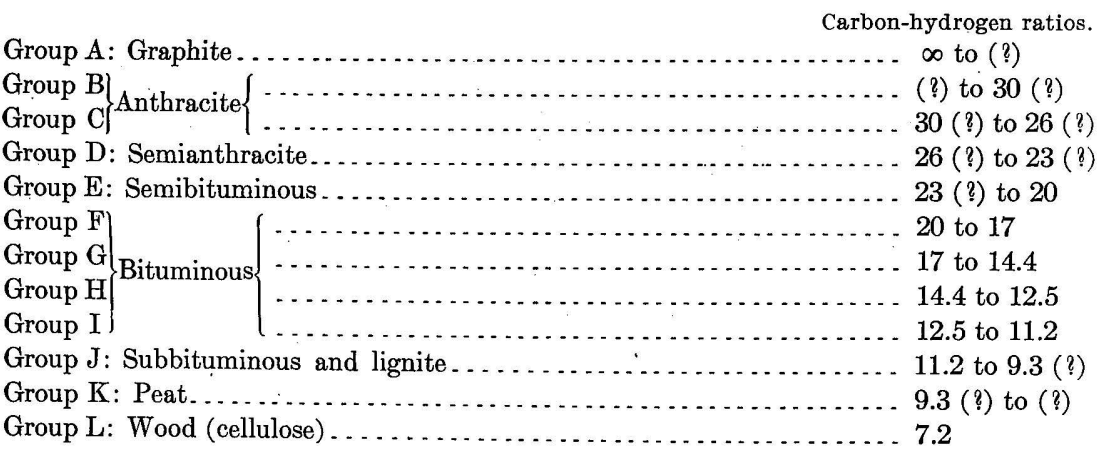

Unfortunately ultimate analyses were made of only a few samples collected during the present survey, but all of those taken from R. C. Hills's report have both the proximate and ultimate analyses given. The uncertainties, however, regarding the moisture content of his samples render the results questionable, since the amount of hydrogen in a given sample of coal depends largely upon the moisture. On the assumption, however, that the samples were dry before analyzing, the results should be nearly the same as when the samples were dried artificially at the coal-testing plant.

The carbon-hydrogen ratios of the three samples of anthracite are 28, 30.6, and 34.8. The only ultimate analysis of Pennsylvania anthracite available for comparison is one of anthracite culm from 
Scranton, Pa., which was analyzed at the coal-testing plant. This gave a ratio of 26.7. From the carbon-hydrogen ratios, therefore, as well as from the fuel ratios of the samples of Dry Creek (Crawford) coal, it seems to be a high-grade anthracite.

The next coal in the list has a carbon-hydrogen ratio of 15.2 (No. 3, p. 86). This is a sample from the anthracite region, and evidently shows the effect of local metamorphism, since the other sample from the same bed of coal (No. 4) shows a ratio of only 11.5. A coal with a ratio of 15.2 would fall into Group $\mathrm{G}$ of the bituminous class, comparing favorably with the Pittsburg coal and high-grade coals of West Virginia. It is probable, however, that the area of this quality of coal in the Yampa field is so small that it would have no greater value than the bulk of the bituminous coals.

The two analyses showing ratios of 13.1 and 12.6 are presumably from the same bed of coal on Oak Creek. This coal belongs in Group $\mathrm{H}$ and, aside from the anthracites in the northern part of the field, is the best coal yet prospected. Its high quality is not due to igneous intrusions, and therefore it is more likely to be of a uniform character over a wide area, at least along the eastern margin of the field. This coal compares very favorably with the bituminous coals of western Kentucky and the highest grades of Iowa and Missouri coals.

The other samples, whose ratios range from 11.2 to 12.4 belong, in Group I, the lowest group in the bituminous class. These are representative of the great bulk of coal in the Yampa field, and they are very much the same in composition as the lowest grades of Iowa, Indiana, and Illinois coals.

The sample which Hills gives from Little Bear Creek is undoubtedly a Laramie coal. Its ratio of 9.8 places it unqualifiedly in Group $J$, which includes all subbituminous coals and lignites, as, on chemical grounds alone, these can not be separated one from the other.

In making the above comparisons of the Yampa coal with coals from other fields and other States, it must be remembered that the comparison is made on the basis of pure coal, and that these comparisons may not hold in actual practice, since the value of a coal in the market is controlled to a large extent by the amount and character of the impurities, such as sulphur and ash.

The distinction between the bituminous and subbituminous classes is undoubtedly largely physical. The subbituminous generally contain more moisture than the bituminous, have a lower calorific value, weather more readily on exposure to the atmosphere, and generally are so light in weight that under forced draft a large percentage is blown out through the smokestack before being consumed. The most marked difference between them is the rapidity with which the subbituminous coals break down in weathering, and also in the peculiar manner in which such breaks occur. In bituminous coal the 
action is mechanical rather than chemical, and the fragments are more or less prismatic, while in subbituminous coal the weathering or "slacking" seems to be the result of a chemical change, the coal usually breaking with an irregular fracture, which does not, as a rule, conform to joint or bedding planes.

\section{UTILIZATION.}

The coals of the Yampa field, as illustrated by the samples analyzed, show a fairly low percentage of ash, only two of the bituminous coals carrying more than 10 per cent in the mine samples, while percentages of 4,5 , and 6 are usually found in the other samples. It is true generally that, owing to lack of care in mining and handling the coal, the ash in coal as it reaches the market is greater than it is in mine samples from the same mine. In the work of mine sampling and testing commercial coal in a large way at the coal-testing plant, ${ }^{a}$ this difference was found to be fairly regular, so that a coefficient of increase of 1.3 was adopted for reducing one to the other. On this basis the ash in commercial coal from this field may reasonably be expected to run as follows:

- Probable percentage of ash in commercial coal from the Yampa field.

\begin{tabular}{|c|c|c|c|}
\hline Sample. & $\begin{array}{l}\text { Per cent } \\
\text { of ash. }\end{array}$ & Sample. & $\begin{array}{l}\text { Per cent } \\
\text { of ash. }\end{array}$ \\
\hline B. & $\begin{array}{r}6.53 \\
13.91\end{array}$ & & $\begin{array}{r}11.37 \\
7.44\end{array}$ \\
\hline & 7.54 & & $\begin{array}{l}7 \\
7\end{array}$ \\
\hline 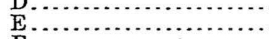 & $\begin{array}{l}11.51 \\
19.04\end{array}$ & $\frac{\mathrm{M}}{\mathrm{N}}$. & $\begin{array}{l}7.57 \\
5.67\end{array}$ \\
\hline …............. & $\begin{array}{l}7.71 \\
1264\end{array}$ & O. & $\begin{array}{l}6.94 \\
5.90\end{array}$ \\
\hline$\stackrel{\mathrm{G}}{\mathrm{H} .}$. & $\begin{array}{r}12.64 \\
7.54\end{array}$ & & $\begin{array}{l}5.90 \\
6.19\end{array}$ \\
\hline
\end{tabular}

The sulphur is low, being generally less than 1 per cent. The greatest sulphur content noted is 1.67 per cent, while the average of all the analyses is 0.71 per cent. This is about the same as Colorado coals generally run, but it is below the sulphur contained in all but the purest eastern coals. In this respect Colorado coal is far ahead of any coal from the Mississippi Valley.

The calorific values of some of the coals are given in the table on page 84. These were determined experimentally in a Mahler bomb calorimeter. An idea of the meaning of these values can be obtained by comparing them with the calorific value of other coals that may be regarded as typical and that were tested in the same machine at St. Louis: 
Calorific values of various coals.

\begin{tabular}{|c|c|c|}
\hline Coals outside of Yampa field. & Coals of Yampa field. & B. T. U. \\
\hline 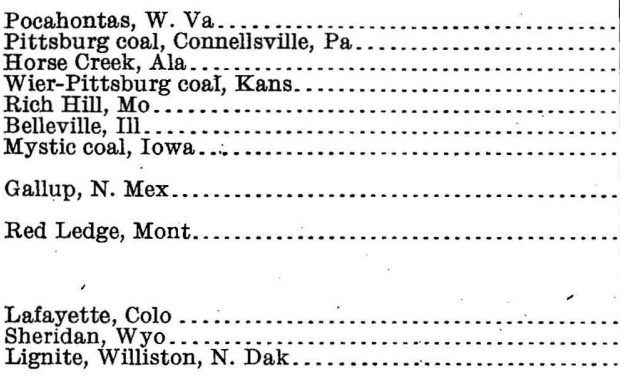 & 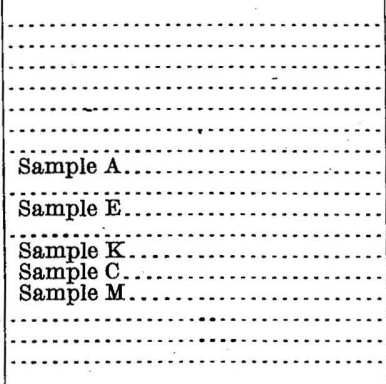 & $\begin{array}{l}15,800 \\
15,500 \\
14,800 \\
14,300 \\
14,000 \\
13,200 \\
12,600 \\
12,447 \\
12,300 \\
12,255 \\
12,100 \\
11,903 \\
11,777 \\
11,681 \\
11,500 \\
10,800 \\
10,200\end{array}$ \\
\hline
\end{tabular}

The best method of utilizing coals depends largely on their character. The anthracite of this field, although of a somewhat limited extent, will doubtless be used largely as a domestic fuel. The bituminous coals will serve well for both domestic and steam purposes. At present the greatest demand in this part of the West is for a good coking coal; but it is very doubtful if any of the coals of the Yampa field belong to this class. Whenever they have been tried they have failed to coke, or have made such an inferior product that they are generally regarded as noncoking. No coking tests were made on the samples that were analyzed, for the reason that an exhaustive series of such tests, together with actual firing of the same coal in standard beehive ovens, seemed to show that no relation exists between results obtained in the crucible and in actual practice.

So far, the interest in the Yampa field is centered around the area which contains bituminous and anthracite coals, and the poorer grades have been considered unworthy of notice. The success at the coal-testing plant at St. Louis of experiments in converting low-grade coals into producer-gas and the utilization of this gas in a gas engine was so pronounced that it seems almost possible now to look ahead to the time when the subbituminous coals, and even the lignites, will be utilized in this way for the production of power. If this is accomplished, the low-grade coals of the Laramie north of Hayden and Craig may have a much greater value than seems possible to-day; and in fact they may successfully compete with the bituminous coals described in this report. 



\section{IN DEX.}

A. Page.

Access, means of.

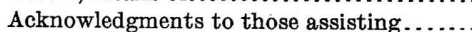

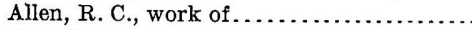

Anomia sp., occurrence of...

Anthracite coal, analysis of . . . . . . . . . . . .

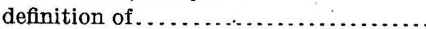
origin of . . . . seam of, view of . . . . . . . . . . 76

Anthracite field, area of ................ $\quad 73$

Anthracite Range, coals of . . . . . . . . . . . . 6. 69-73 description of .................... 63-64 metamorphism in ................. 68 rocks of ........................ 68 volcanic phenomena of ............... . 68-69 Archean rocks, occurrence and description

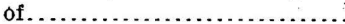

Ash, percentage of, in Yampa coal........ Axial Basin, description of...............

\section{B.}

Badger Gulch, coal in

Barnes, J. J., development by

Barnes mine, coals of.

Basalt, occurrence and description of.....

Berry Gulch, coal in.

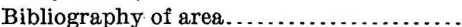

Big Bottom anticline, location of . . . . . . . .

Bituminous coal, analyses of . .............

definition of. . . . . . . .

occurrence of . . . . . . . . . . . . . 35,82

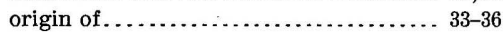

Blamey, J. S., development by ........... 61

Brooks mine, coals of. ................. 52-53

Butcherknife Creek, coal of, analysis of.... . 84 coals on........................ 66 section of $\ldots \ldots \ldots \ldots \ldots \ldots \ldots \ldots \ldots$

- $\quad$ C.

California Park, coal of 75-76

Calorific value of Yampa coals. 90-91

Campbell, M. R., on character and use of Yampa coals. 82-91 on classification of coals. $87-90$ work of.

Canyon coal field location of

Carbon-hydrogen ratio, classification by ... 88-89

Carlyn, W. M., ranch of, coal on......... 56-57

Chrisney mine, coal of..

Clarke Canyon, oil well in ............... 80

Classification of coals.................... 8. 87-90

Coals, analyses of..................... 84-85

ash in

$84-85$
90

calorific value of.
Coals, character of .

Page.

classification of

geologic position of . ................. 17,19

markets for ........................... 36

metamorphism of . . . . . . . . . . . . . $33-36$

occurrence of . . . . .................. 33-79

sampling of, methods of . .............. 82-83

seams of, measurements of. .......... 26

sections of . . . . . . . .

views of . . . . . . 76

utilization of . . . . . . . . . . . . . . . . . . 90-91

value of, for producer-gas. ........... 91

See also Coking coals; Anthracite coal;

Bituminous coal; Subbituminous coal.

Coking coal, occurrence of................ 35

Colorado, coal fields of, area of........... ' 33

coal fields of, distribution of.......... $\quad 33$

location of ..................... 33

map showing ............... 34

coals of, production of............... 33

character of . .................... $\quad 35$

previous maps of, character of ...... 9-10

Colorado group, subdivisions of........... 18

Colorado River, drainage of............. 8

Columbine, Colo., shaft at, record of....... 21

Continental Divide, location of............ 8

Corbula undifera, occurrence of . . . . . . . . 49,51

Craig, coals near ..................... 60-63

rocks near. . . . . . . . . . . . . . . . . . . . 32

structure near. ................... 15-16

Crawford tract, coals of . . ............... 69-70 coals of, analyses of ................... 84

Cretaceous rocks, classifications of. ...... 18-20 occurrence and description of. ....... 21-31

Cross, Whitman, on Lewis shale........ 28 on Mancos shale................... 22

on Mesaverde formation ............. 22-23

Cuestas, definition of . . ................ 14 occurrence of . .................... 14

D.

Dakota formation, geologic position of.... 20 occurrence and description of........ 21-22 section of. . . ..................... 21

Dana, J. D., on faults............... 16

Deal Gulch, coal.in................... $\quad 58$ coal in, section of. .................. . 58

Deep Creek, coal from, analysis of ......... 86

Deer Creek district, coals of . . . . . . . . . . 59-60 coals of, section of ................. 60

Diamond Drill Hill, coal at............ 76

Dikes, occurrence of................... 32

Drainage, description of . ............. $8-9$ 
Dry Creek, coals of .................. Page. coals of, analyses of . . . . . . . . . . . description of ..................... 56

Dry Creek district, coals of ........... 56-57 coals of, section of. ................ 56

Ducey tunnel, coal in .................. 71

Dunkley Canyon, sections in ............. 40 view in ................... 40

Dunkley Canyon district, coals of . . . . . . . 40-41 coals of, sections of................ 40 geology of.

Durango-Gallup coal field, location of..... E.

Eckman Park, coal in

Eddy, coals near . . . . . . ............... 47-51

fault near .......................... 16-17

fossils near...................... 22

geology near................... 47

rocks near. . . . . . . . . . . . . . . . . 31,32

sections near . . . . . . . . . . . . . . . . . 48, 49

Eddy district, coals of ................ 47-51

coals of, sections of . . . . . . . . . . . . . . 48, 49 description of .................... 47

geology of........................ 47

Egeria Coal Co., development by.......... 77

Egeria Gulch, structure in.............. 15,24

Elk Mountain, rocks of.............. 32,33,68

Elk River, oil well on.

Elkhead and Quaker Mountain district, coals of. . . . . . . . . . . . . $74-79$

sections in .................... $76-79$

descriptión of ...................... 74

Elkhead Creek, coal on . . . . . . . . . . 73,76-77,78

coal on, section of. ............... $76-77$

rocks on . . . . . . . . . . .

view on

Elkhead Mountains, coals of . . . . . . . . . . . 74-79 coals of, sections of . ............ 76-77,79

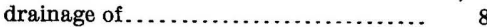

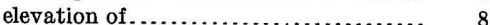
rocks in.

Emmons, S. F., work of.

\section{F.}

Faults, definition of. .................. 16 occurrence and description of.... 16-17,48-49

Fish Creek, coal on . .................... 49,50 coal on, section of. rocks on

Flat Top Mountain, rocks near. fault near

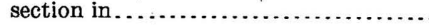

Folds, minor, descriptions of ........... 14-17 distribution of ................... 13 See also Syncline.

Formations, descriptions of ........... 20-33

Fortification Creek, coal on .............. 78

Fossils, occurrence of .................. 22, 29 stratification by aid of .............. 19

Fox Hills, geologic position of ........... 20 Frazer, Persifor, jr., classification by ..... $\quad 87$

\section{G.}

Gale, Hoyt S., on Yamp coal field ........ 8-81 work of $\ldots \ldots \ldots \ldots \ldots \ldots \ldots \ldots \ldots \ldots \ldots . .96$

Gantt's ranch, coal near............... 75-76
Page.

Gartman, F. H., developments by....... 66

Gas, producer, value of coals for......... 91

Geography, description of ............ 8-9

Geologic map of Yampa field ............ 20 compilation of ..................... 20

Grand River coal field, location of ......... 33

Grassy Gap, location of . ................ 14

structure at....................... 14

Gravel, occurrence of ................. 15,31

Greeley prospects, coal of . . . . . . . . . . . 60-61

coal of, section of .................. 61

Green mine, coal of .................. 57

Green River, description of .............. 8

H.

Hahns Peak, rocks of and near . . . . . . 21, 32,33

Hamilton, coals near . . . . . . . . . . . . . . . . . 58-59 fault near...................... 17

Hamilton, T. H., development, by . ......... 60

Hamilton distriet, coals of . . . . . . . . . . 58-59

Haubrich coal bank, description of . ....... 62

Hayden, oil near...................... 81 structure near. . . . . . . . . . . . . . . . . . 15-16

Hayden, F. V., mapping by ............ 9-10,17 See also Meek and Hayden.

Hayden Gulch, coal of, analysis of ........ 84

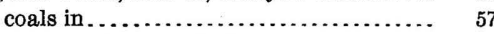

Hayden openings, coal of .............. 74-75

Hill, N. P., drilling by . . . . . . . . . . . . . . . . . 80

Hills, R. C., analyses by.............. $85-86,88$ on stratification................... 19 work of $\ldots . . \ldots \ldots \ldots \ldots \ldots \ldots \ldots \ldots . . .11$

Hitchens mine, coals of ............... 51

Holmes, W. H., on Mesa Verde group..... 22

Hooker Mountain, rocks near.......... 32

Hutchinson property, coal on ........... 50 coal on, analysis of ................. 84

I.

Igneous rocks, occurrence and description of . . . . . . . . . . . . .

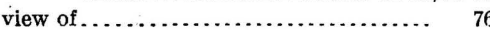

Inoceramus sp., occurrence of . . . . . . . . 22

J.

James mine, description of . . . . . . . . . . 41-42 sections in ....................... $41-42$

Jameson, W. I., development by. . . . . . . 60-77

Jones mine, coal of ................... 48 section of . . . . . . . . .

Jurassic-Triassic rocks, geologic position of. $\quad 20$ occurrence and description of ......... 21

$\mathbf{K}$

Keitel mine, description of ............. 71

Kellog coal bank, description of . ......... 60

Kimberley coal bank, description of ........ 62 King, Clarence, mapping by ............ 9-10,17

\section{L}

Land Office surveys, maps of ........... 10-11

Literature on the region. ................ 11

Laramie formation, coals of . . .... 17, 29,62, 74-79 limits of ......................... 18-19 occurrence and description of. . . . . . . 29-31

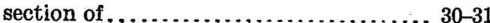


Lay, coal near $\quad$ Page.

oil near.

salt at.

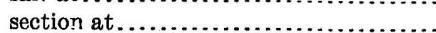

Lay Creek, coal from, analysis of. gas on .

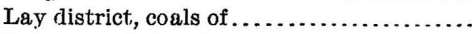

Lennox seal, description of . .....

Lewis shale, geologic position of. . . . . . . . 20-28 occurrence and description of........ 28-29,

$37,38,40,75$

Lignite, definition of 87 occurrence of. See also Coal.

Lingula sp., occurrence of . .

I ittle Bear Creek (Bry Fork), coal from, analysis of .................. coal near, section of . . . . . . . . . . . . $\quad 79$ coal on ........................... $78-79$

Little Fish.Creek, coal from, analysis of... 86

Little Snake River, drainage of .......... 8

Location $n$ area...................... 7,33 index map showing.

\section{M.}

McCrosky, Z., mine of, coal of. mine of, coal of, analysis of section of.

Male mine, coal of coal of, section of

Mancos shale occurrence and description of .46

Map, base, preparation of . . . . . . . . . . . . 10-11

Map, geologic, of Yampa field .......... 20 compilation of . .................... 20

Map, index, of Colorado coal fields....... $\quad 34$

Maps, topographic, description of ........ 9-11

Markets, available, location of .......... 36

Meek and Hayden, rnck classification by ... 17

Mesa Verde group, application of ........ 22

Mesaverde formation, coals in . . . . . . . 23, 37-73 coals in, sections of, 24 ........ passim $37-37$ geologic position of.

occurrence and description of.. $22-28,38,40,47$ outcrop of $\ldots \ldots \ldots \ldots \ldots \ldots \ldots \ldots \ldots 13,14,15$ view of

sections of $\ldots \ldots \ldots \ldots \ldots \ldots \ldots 23,24,25,26,27,28$ view of ...

Metamorphism, processes of ............ 33-36

Middle Creek, canyon of, coal in . .......... ${ }_{46}$ fault on ......................... 17

Middle Park coal field, location of ........ . 33

Miller Gulch, coal of, analysis of ........ 84 coals of . . . . . . . . . . . . .

Miller oil well, data on ................. 80

Montana formation, coals of . . . . . . . . . . 17

Montana group, subdivisions of . . . . . . 18, 19-20

Morgan tract, coals of . . ................ . $70-71$

\section{N.}

North Park coal field, location of .

\section{O.}

Oak Creek, coal from, analysis of ......... 86 coal on and near ................... 41,44 section of description of................... 41

Oak Creek district, coals of ............. 41-44 coals of, sections of . . . . . . . . . . . . . $41-44$
Page.

Oak Creek district, description of........ 41 Oil springs, occurrence and description of ... $\quad 79$ Ostrea congesta, occurrence of.......... 22

P.

Pagoda, section near.................. 24

Pallas, coal near........................ 41

Park Range, description of ............. 8 elevations of ..................... 8

Peacock seam, position of.............. 63

Pennsylvania coals, classification of ...... 87 comparison of Yampa coals and...... . 88 metamorphism of................ 34

Petroleum, occurrence of . . . . . . . . . . . 79-81 springs of ................. 79

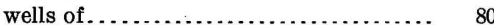

Pilot Knob, coal on and near.......... 71-72 rocks of . . . . . . . . . . . . . . . . . . . . . 32,88

Pinnacle, coal near . . . . . . . . . . . . 41,45 rocks near........................ 32

Pool, coal near. ...................... 53 oil springs near................... $\quad 79$ oil wells near. ................... 80

Pool district, coals of................ 51-53 coals of, sections of $\ldots \ldots \ldots \ldots \ldots \ldots \ldots 52,53$ description of ................... 51

Potholes, coal at . . . . . . . . . . . . . . . . . . 76-77 location of .................... 76 view at ....................... 76

Q.

Quaker Mountain, coals of ........... 75-78 coals of, section of. . . . . . . . . rocks of ....................... 32

R.

Railroads, access by .................. 7

Ratcliff coal bank, description of ......... 61

Raton coal field, location of .............. 33

Red Beds, occurrence and description of... 21 geologic position of ................ 20

Reed seam, occurrence and description of.. 67

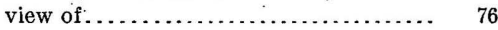

Relief, description of ................. 8

Rocks, age of . . . . . . . .

classifications of . . . . . . . . . . . . . . .

descriptions of .................. 20-33

previous study of. . . . . . . . . . . . . 17-20

section of ...................... 20

stratigraphy of ..................... 20

See also particular formations.

Rocky Mountain coals, metamorphism of.. 34

S.

Saddle Mountain, coal of . . . . . . . . . . . . $\quad 75$

Sage Creek, coals on . ................... $\quad 26$

Sage Creek Canyon, coal of, analysis of..... 84

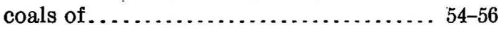

description of .................... 54

sections in . . . . . . . . . . . . . .

Sage Creek anticline, location and description of . . . . . . . . . . . .

Sand Mountain, coals on . . . . . . . . . . ... 73

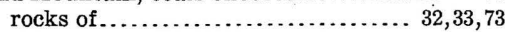

Scaphites nodosus, occurrence of......... 29

School-section mine, coal of............ 71

Scott mine, coals of.................... $\quad 57$

Section, general, of Colorado rocks........ . plate showing .................. 18 
Semianthracite coal, definition of Page Semibituminous coal, definition of....... 87 Seymour mine, coal of . . . . . . . . . . . . . . . . . 78-79

Shelton tract, coals of. . . . . . . . . . . . . . . $72-73$

Shuster mine, coal from, analysis of....... 84 description of ...................... 42-43 sections in . . ....................... 42-43

South Platte coal field, location of....... 33

Stanton, F. M., analyses by ............ 84,85

Stanton, T. W., fossils determined by ...... 22,29 measurements by $\ldots \ldots \ldots \ldots \ldots \ldots \ldots \ldots . \quad 49$ work of.

Steamboat Springs Electric Company mine, description of . .............. 43- $\$ 4$ section of . . ...................... 43

Stratigraphy, account of. . . . . . . . . . . . 20-33

Structure, features of................. 12-17 map showing See also Syncline; Folds.

Stukey, Daniel, section by............... 21

Stukey oil well, data on................ 80

Subbituminous coal, definition of . . . . . 8 87,89-90 occurrence of ..................... 74

Sweeny tunnel, coals in ................. 63

Syncline, major, description of . . . . . . . . . 12-13

T.

Taff, J. A., reed-like coal seam noted by.... 68

Tertiary gravels, correlation of........... 31

- occurrence and description of......... . 15,31

Topographic maps, description of . ....... . 9-11

Tow Creek, coal on .................... 53

coal on, section of .................. 53

oil in........................... 79

rocks on

Tow Creek anticline, location and description of . ....................... 13,14 rocks of

Trout Creek, canyon of, coal of.

canyon of, coal of, analysis of........................... structure in

coal of, section of

description of

faults along

rout Creek Canyon district, coals of . . . . . 45-47 coals of, section of . ................ 45,46

Trout Creek sandstone member, occurrence and description of ........ 15,26,65

Tufts, W. O., work of................ 9 view of

Twentymile basin, coals of . . . . . . . . . . . 37-53 coals of, sections of . ..... 38, 40-46,48-49,52-53 geology in ....................... 37 location and description of . . . 13, 14-15, 36-53 sandstone in, view of . ............... 22 structure and subdivisions of......... 37 plate showing

Twentymile Park district, coals of . . . . . . . 38-39 coals of section of . ................... 38 description of $\ldots \ldots \ldots \ldots \ldots \ldots \ldots \ldots . .14$ elevation of ........................ 14 geology of ........................ 38

Twentymile sandstone member, ledges of, view of. . . . . . . . . . . . . . . . 22, 28 occurrence and description of. . . . . . . 15,27 U.

Unio sp., occurrence of. 49,77
V.

Page.

Volcanic stocks, description of . . . . . . . . 32-33

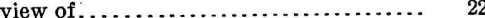

W.

Wadge ranch, Twentymile sandstone at view of . $\ldots \ldots \ldots \ldots \ldots \ldots \ldots \ldots .28$

Wadge seam, coal of, analysis of ......... 84 description of ..................... 65

Walker coal bank, description of . . . . . . . . 62

Wallihan, A. G., development by......... 63

Whetstone property, coal on ........... 47-48

White, C. A., on Axial basin ........... 13 on Green River.................... 8 on stratification.................. 18 work of........................... 11

White River, drainage of . . . . . . . . 8

White River plateau, drainage of......... 8 elevations on .................... 8

Williams Fork, gulches near, coal in . . . . . 57-58 rocks on . . . . . . . . . . 40 structure near...................... 16

Williams Fork Mountains, coal of ....... 54-63 coal of, sections of ............. 56,58,60,61 description of ...................... 53-54 structure and subdivisions of ......... 54

Williams Park, view in $\ldots . . . . .24$

Wise coal bank, description of. .......... 61

Wolf Creek, coal on ................ 64,67-68 coal on, view of ................... 76 description of . . . . . . . . . . . . . . . . . 66-67

Wolf Creek district, coals of. . . . . . . . . . 64-68 description of ..................... 63-64

Wolf Creek seam, location of............ 66

Wolf Mountain, coals on ................ 67

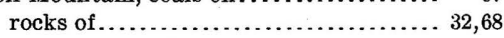

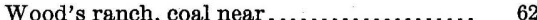

\section{$Y$.}

Yampa, rocks near....................... 32 section near...................... 25 volcanic stocks near, view of......... 22

Yampa Canyon, coals of... . . . . . . . . . . . 64-68 sections of ....................... 64,66 views in . . . . . . . . . . . . . . Yampa coal field, coals of, character and use of .................... 82-91 description of................... $33-79$ economic geology of . . . . . . . . . . . . . . . 33-81 geography of . .............. 8-9 geologic map of.................... . 20

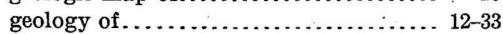
location of. ....................... 7,33 index map showing............. 34 map of . ......................... Pocket. petroleum of . . . . . . . . . . . . . rocks of .................... 17-33 structure of. . . . . . . . . . . section of ....................... 20 plate showing ................... 18

Yampa River, description of .......... 8-9 elevations along................... 8 rocks on ........................ 14,21

Yampa Valley, coals of ..............60 60 63 coals of, section of ................. 61

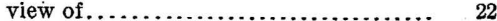




\section{CLASSIFICATION OF THE PUBLICATIONS OF THE UNITED STATES GEOLOGICAL SURVEY.}

[Bulletin No. 297.]

The serial publications of the United States Geological Survey consist of (1) Annual Reports, (2) Monographs, (3) Professional Papers, (4) Bulletins, (5) Mineral Resources, (6) Water-Supply and Irrigation Papers, (7) Topographic Atlas of United States-folios and separate sheets thereof, (8) Geologic Atlas of the United Statesfolios thereof. The classes numbered 2, 7, and 8 are sold at cost of publication; the others are distributed free. A circular giving complete lists may be had on application.

Most of the above publications may be obtained or consulted in the following ways:

1. A limited number are delivered to the Director of the Survey, from whom they may be obtained, free of charge (except classes 2, 7, and 8), on application.

2. A certain number are delivered to Senators and Representatives in Congress for distribution.

3. Other copies are deposited with the Superintendent of Documents, Washington, D. C., from whom they may be had at practically cost.

4. Copies of all Government publications are furnished to the principal puiblic libraries in the large cities throughout the United States, where they may be consulted by those interested.

The Professional Papers, Bulletins, and Water-Supply Papers treat of a variety of subjects, and the total number issued is large. They have therefore been classified into the following series: A, Economic geology; B, Descriptive geology; C, Systematic geology and paleontology; D, Petrography and mineralogy; E, Chemistry and physics; F, Geography; G, Miscellaneous; H, Forestry; I, Irrigation; J, Water storage; K, Pumping water; L, Quality of water; M, General hydrographic investigations; N, Water power; O, Underground waters; P, Hydrographic progress reports. This paper is the eighty-fourth in Series $A$ and the one hundred and fourth in Series $\mathrm{B}$, the complete lists of which follow ( $\mathrm{PP}=$ Professional Paper; $\mathrm{B}=$ Bulletin; WS $=$ Water-Supply Paper):

\section{SERIES A, ECONOMIC GEOLOGY.}

B 21. Lignites of Great Sioux Reservation: Report on region between Grand and Moreau rivers, Dakota, by Bailey Willis. 1885. 16 pp., 5 pls. (Out of stock.)

B 46. Nature and origin of deposits of phosphate of lime, by R. A. F. Penrose, jr., with introduction by N. S. Shaler. $1888.143 \mathrm{pp.} \mathrm{(Out} \mathrm{of} \mathrm{stock.)}$

B 65. Stratigraphy of the bituminous coal field of Pennsylvania, Ohio, and West Virginia, by I. C. White. 1891. $212 \mathrm{pp} ., 11 \mathrm{pls}$. (Out of stock.)

B 111. Geology of Big Stone Gap coal field of Virginia and Kentucky, by M. R. Campbell. 1893. 106 pp., 6 pls. (Out of stock.)

B 132. The disseminated lead ores of southeastern Missouri, by Arthur Winslow. 1896. 31 pp. (Out of stock.)

B 138. Artesian-well prospects in Atlantic Coastal Plain region, by N. H. Darton. 1896. 228 pp., 19 pls.

B 139. Geology of Castle Mountain mining district, Montana, by W. H. Weed and L. V. Pirsson. 1896. 164 pp., 17 pls.

B 143. Bibliography of clays and the ceramic arts, by J. C. Branner. $1896.114 \mathrm{pp}$

B 164. Reconnaissance on the Rio Grande coal fields of Texas, by T. W. Vaughan, including a report on igneous rocks from the San Carlos coal field, by E. C. E. Lord. 1900.100 pp., 11 pls. (Out of stock.)

Bull. $297-06-7$ 
B 178. El Paso tin deposits, by W. H. Weed. 1901. 1ō pp., 1 pl.

B 180. Occurrence and distribution of corundum in United States, by J. H. Pratt. 1901. 98 pp., 14 pls. (Out of stock: see No. 269.)

B 182. A report on the economic geology of the Silverton quadrangle, Colorado, by F. L. Ransome. 1901. 260 pp., 16 pls. (Out of stock.)

B 184. Oil and gas fields of the western interior and northern Texas Coal Measures and of the Upper Cretaceous and Tertiary of the western Gulf coast, by G. I. Adams. 1901. 64 pp., 10 pls. (Out of stock.)

B 193. The geological relations and distribution of platinum and associated metals, by J. F. Kemp. 1902. 95 pp., 6 pls.

B 198. The Berea grit oil sand in the Cadiz quadrangle, Ohio, by W. T. Griswold. 1902.43 pp., 1 pl. (Out of stock.)

PP 1. Preliminary report on the Ketchikan mining district, Alaska, with an introductory sketch of the geology of southeastern Alaska, by A. H. Brooks. 1902.120 pp., 2 pls.

B 200. Reconnaissance of the borax deposits of Death Valley and Mohave Desert; by M. R. Campbell. 1902. $23 \mathrm{pp} ., 1 \mathrm{pl}$. (Out of stock.)

B 202. Tests for gold and silver in shales from western Kansas, by Waldemar Lindgren. $1902.21 \mathrm{pp}$. (Out of stock.)

PP 2. Reconnaissance of the northwestern portion of Seward Peninsula, Alaska, by A. J. Collier. 1902. $70 \mathrm{pp}$., 11 pls.

PP 10. Reconnaissance from Fort Hamlin to Kotzebue Sound, Alaska, by way of Dall, Kanuti, Allen, and Kowak rivers, by W: C. Mendenhall. 1902.68 pp., 10 pls.

PP 11. Clays of the United States east of the Mississippi River, by Heinrich Ries. 1903.298 pp., 9 pls.

PP 12. Geology of the Globe copper district, Arizona, by F. L. Ransome. 1903.168 pp., 27 pls.

B 212. Oil fields of the Texas-Louisiana Gulf Coastal Plain, by C. W. Hayes and William Kennedy. 1903. 174 pp., 11 pls. (Out of stock.)

B 213. Contributions to economic geology, 1902; S. F. Emmons and C. W. Hayes, geologists in charge. 1903. $449 \mathrm{pp.}$ (Out of stock.)

PP 15. The mineral resources of the Mount Wrangell district, Alaska, by W. C. Mendenhall and F. C. Schrader. 1903.71 pp., 10 pls.

B 218. Coal resources of the Yukon, Alaska, by A. J. Collier. $1903.71 \mathrm{pp}, 6$ pls.

B 219. The ore deposits of Tonopah, Nevada (preliminary report), by J. E. Spurr. $1903.31 \mathrm{pp} ., 1 \mathrm{pl}$. (Out of stock.)

PP 20. A reconnaissance in northern Alaska in 1901, by F. C. Schrader. 1904.139 pp., 16 pls.

PP 21. Geology and ore deposits of the Bisbee quadrangle, Arizona, by F. L. Ransome. 1904. 168 pp., 29 pls.

B 223. Gypsum deposits in the United States, by G. I. Adams and others. 1904.129 pp., 21 pls.

PP 24. Zinc and lead deposits of northern Arkansas, by G. I. Adams. 1904.118 pp., 27 pls.

PP 25. Copper deposits of the Encampment district, Wyoming, by A. C. Spencer. 1904.107 pp., 2 pls.

B 225. Contributions to economic geology, 1903, by S. F. Emmons and C. W. Hayes, geologists in charge. 1904. $527 \mathrm{pp} ., 1 \mathrm{pl}$. (Out of stock.)

PP 26. Economic resources of the northern Black Hills, by J. D. Irving, with contributions by S. F. Emmons and T. A. Jaggar, jr. 1904. 222 pp., 20 pls.

PP 27. A geological reconnajssance across the Bitterroot Range and Clearwater Mountains in Montana and Idaho, by Waldemar Lindgren. 1904.123 pp., 15 pls.

B 229. Tin deposits of the York region, Alaska, by A. J. Collier. 1904. 61 pp., 7 pls.

B 236. The Porcupine placer district, Alaska, by C. W. Wright. $1904.35 \mathrm{pp} ., 10 \mathrm{pls}$.

B 238. Economic geology of the Iola quadrangle, Kansas, by G. I. Adams, Erasmus Haworth, and W. R. Crane. 1904. $83 \mathrm{pp} ., 11 \mathrm{pls}$.

B 243. Cement materials and industry of the United States, by E. C. Eckel. 1905.395 pp., 15 pls.

B 246. Zinc and lead deposits of northwestern Illinois, by H. Foster Bain. 1904. 56 pp., 5 pls.

B 247. The Fairhaven gold placers of Seward Peninsula, Alaska, by F. H. Moffit. 1905.85 pp., 14 pls.

B 249. Limestones of southeastern Pennsylvania, by F. G. Clapp. 1905.52 pp., 7 pls.

B 250. The petroleum fields of the Pacific coast of Alaska, with an account of the Bering River coal deposits, by G. C. Martin. 1905. 65 pp., 7 pls.

B 251. The gold placers of the Fortymile, Birch Creek, and Fairbanks regions, Alaska, by L. M. Prindle. 1905. 89 pp., 16 pls.

WS 117. The lignite of North Dakota and its relation to irrigation, by F. A. Wilder. 1905.59 pp., 8 pls.

PP 36. The lead, zinc, and fluorspar deposits of western Kentucky, by E. O. Ulrich and W. S. T. Smith. 1905. $218 \mathrm{pp} ., 15 \mathrm{pls}$.

PP 38. Economic geology (f the Bingham mining district, Utah, by J. M. Boutwell, with a chapter on areal geology, by Arthur Keith, and an introduction on general geology; by S. F. Emmons. 1905. $413 \mathrm{pp}$., $49 \mathrm{pls}$.

PP 41. Geology of the central Copper River region, Alaska, by W. C. Mendenhall. 1905. 133 pp., 20 pls.

B 254. Report of progress in the geological resurvey of the Cripple Creek district, Colorado, by Waldemar Lindgren and F. L. Kansome. $1904.36 \mathrm{pp}$.

B 255. The fluorspar deposits of southern Illinois, by H. Foster Bain. 1905. 75 pp., 6 pls. 
B 256. Mineral resources of the Elders Ridge quadrangle, Pennsylvania, by R. W. Stone. 1905. 86 pp., 12 pls.

B 259. Report on progress of investigations of mineral resources of Alaska in 1904, by A. H. Brooks and others. 1905. 196 pp., 3 pls.

B 260. Contributions to economic geology, 1904; S. F. Emmons and C. W. Hayes, geologists in charge. 1905. 620 pp., 4 pls.

B 261. Preliminary re ort on the operations of the coal-testing plant of the United States Geological Survey at the Louisiana Purchaise Exposition, St. Louis, Mo., 1904; E. W. Parker, J. A. Holmes, and M. R. Campbell, committee in charge. $1905.172 \mathrm{pp.} \mathrm{(Out} \mathrm{of} \mathrm{stock.)}$

B 263. Methods and cost of gravel and placer mining in Alaska, by C. W. Purington. 1905.273 pp., 42 pls.

PP 42. Geology of the Tonopah mining district, Nevada, by J. E. Spurr. 1905.295 pp., 24 pls.

PP 43. The copper deposits of the Clifton-Morenci district, Arizona, by Waldemar Lindgren. 1905. 375 pp., 25 pls.

B 264. Record of deep-well drilling for 1904, by M. L. Fuller, E. F. Lines, and A. C. Veatch. 1905. $106 \mathrm{pp}$.

B 265. Geology of the Boulder district, Colorado, by N. M. Fenneman. 1905. 101 pp., 5 pls.

B 267. The copper deposits of Missouri, by H. Foster Bain and E. O. Ulrich. $1905.52 \mathrm{pp} ., 1 \mathrm{pl}$.

B 269. Corundum and its occurrence and distribution in the United States (a revised and enlarged edition of Bulletin No. 180), by J. H. Pratt. 1906.175 pp., 18 pls.

PP 48. Report on the operations of the coal-testing plant of the United States Geological Survey at the Louisiana Purchase Exposition, St. Louis, Mo., 1904; E. W. Parker, J. A. Holmes, M. R. Campbell, committee in charge. 1906. (In 3 parts.) 1492 pp., 13 pls.

B 275. Slate deposits and slate industry of the United States, by T. N. Dale, with sections by E. C. Eckel, W. F. Hillebrand, and A. T. Coons. 1906.154 pp., 25 pis.

PP 49. Geology and mineral resources of part of the Cumberland Gap coal field, Kentucky, by G. H. Ashley and L. C. Glenn, in cooperation with the Stute Geological Department of Kentucky, C. J. Norwood, curator. 1906.239 pp., 40 pls.

B 277. Mineral resources of Kenai Peninsula, Alaska: Gold fields of the Turnagain Arm region, by - F. H. Moffit; Coal fields of the Kachemak Bay region, by R. W. Stone. 1906.80 pp., 18 pls.

B 278. Geology and coal resources of the Cape Lisburne region, Alaska, by A. J. Collier. 1906.54 pp., 9 pls.

B 279. Mineral resources of the Kittanning and Rural Valley quadrangles, Pennsylvania, by Charles Butts. $1906 . \quad-$ pp., 11 pls.

B 280. The.Rampart gold placer region, Alaska, by L. M. Prindle and F. L. Hess. $1906.54 . p p ., 7$ pls.

B 282. Oil fields of the Texas-Louisiana Gulf Coastal Plain, by N. M. Fenneman. 1906.146 pp., 11 pls.

PP 51. Geology of the Bighorn Mountains, by N. H. Darton. 1906. 129 pp., 47 pls.

B 283. Geology and mineral resources of Mississippi, by A. F. Crider. 1906.99 pp., 4 pls.

B 284. Report on progress of investigations of the mineral resources of Alaska in 1905, by A. H. Brooks and others. 1906.169 pp., 14 pls.

B 285. Contributions to Economic Geology, 1905; S. F. Emmons and E. C. Eckel, geologists in charge. 1906. 506 pp., 13 pls.

B 286. Economic geology of the Beaver quadrangle, Pennsylvania, by L. H. Woolsey. $1906 . \quad-$ pp. 8 pls.

B 287. Juneau gold belt, Alaska, by A. C. Spencer, and A reconnaissance of Admiralty Island, Alaska, by C. W. Wright. 1906.161 pp., 27 pls.

PP 54. The geology and gold deposits of the Cripple Creek district, Colorado, by W. Lindgren and F. L. Ransome. $1906 . \quad$ - pp., 29 pls.

PP 55. Ore deposits of the Silver Peak quadrangle, Nevada, by J. E. Spurr. 1906.174 pp., 24 pls.

B 289. A reconnaissance of the Matanuska coal field, Alaska, in 1905, by G. C. Martin. 1906.34 pp., 5 pls.

B 290. Preliminary report on the operations of the fuel-testing plant of the United States Geological Survey at St. Louis, Mo., 1905, by J. A. Holmes. 1906.240 pp.

B 293. A reconnaissance or some gold and tin deposits of the southern Appalachians, by L. C. Graton, with notes on the Dahlonega mines, by W. Lindgren. 1906.134 pp., 9 pls.

B 294. Zinc and lead deposits of the upper Mississippi Valley, by H. Foster Bain. $1906 . \quad$ - pp., 16 pls.

B 295. The Yukon-Tanana region, Alaska, description of Circle quadrangle, by L. M. Prindle. 1906. 27 pp., 1 pl.

B 296. Economic geology of the Independence quadrangle, Kansas, by Frank C. Schrader and Erasmus Haworth. 1906. - pp., 6 pls.

B 297. The Yampa coal field, Routt County, Colo., by N. M. Fenneman, Hoyt S. Gale, and M. R. Campbell. 1906. 96 pp., 9 pls.

\section{SERIES B, DESCRIPTIVE GEOLOGY.}

B 23. Observations on the junction between the Eastern sandstone and the Keweenaw series on Keweenaw Point, Lake Superior, by R. D. Irving and T. C. Chamberlin. 1885.124 pp., 17 pls. (Out of stock.) 
B 33. Notes on geology of northern California, by J. S. Diller. 1886. 23 pp. (Out of stock.)

B 39. The upper beaches and deltas of Glacial Lake Agassiz, by Warren Upham. 1887.84 pp., 1 pl. (Out of stock.)

B 40. Changes in river courses in Washington Territory due to glaciation, by Bailey Willis. 1887.10 pp., 4 pls. (Out of stock.)

B 45. The present condition of knowledge of the geology of Texas, by R. T. Hill. $1887 . \quad 94$ pp. (Out of stock.)

B 53. The geology of Nantucket, by N. S. Shaler. 1889.55 pp., 10 pls. (Out of stock.)

B 57. A geological reconnaissance in southwestern Kansas, by Robert Hay. 1890.49 pp., 2 pls.

B 58. The glacial boundary in western Pennsylvania, Ohio, Kentucky, Indiana, and Illinois, by G. F. Wright, with introduction by T. C. Chamberlin. 1890. 112 pp., 8 pls. (Out of stock.)

B 67. The relations of the traps of the Newark system in the New Jersey region, by N. H. Darton. 1890. $82 \mathrm{pp.} \mathrm{(Out} \mathrm{of} \mathrm{stock.)}$

B 104. Glaciation of the Yellowstone Valley north of the Park, by W. H. Weed. 1893.41 pp., 4 pls.

B 108. A geological reconnaissance in central Washington, by I. C. Russell. 1893.108 pp., 12 pls. (Out of stock.)

B 119. A geological reconnaissance in northwest Wyoming, by G. H. Eldridge. 1894.72 pp., 4 pls.

B 137. The geology of the Fort Riley Military Reservation and vicinity, Kansas, by Robert Hay. 1896. 35 pp., 8 pls.

B 144. The moraines of the Missouri Coteau and their attendant deposits, by J. E. Todd. 1896.71 pp., 21 pls.

B 158. The moraines of southeastern South Dakota and their attendant deposits, by J. E. Todd. 1899. 171 pp., 27 pls.

B 159. The geology of eastern Berkshire County, Massachusetts, by B. K. Emerson. 1899.139 pp., 9 pls.

B 165. Contributions to the geology of Maine, by H. S. Williams and H. E. Gregory. $1900 . \quad 212$ pp., 14 pls.

WS 70. Geology and water resources of the Patrick and Goshen Hole quadrangles in eastern Wyoming and western Nebraska, by G. I. Adams. 1902. 50 pp., 11 pls.

B 199. Geology and water resources of the Snake River Plains of Idaho, by I. C. Russell. 1902.192 pp., 25 pls.

PP 1. Preliminary report on the Ketchikan mining district, Alaska, with an introductory sketch of the geology of southeastern Alaska, by A. H. Brooks. 1902.120 pp., 2 pls.

PP 2. Reconnaissance of the northwestern portion of Seward Peninsula, Alaska, by A. J. Collier. 1902. 70 pp., 11 pls

PP 3. Geology and petrography of Crater Lake National Park, by J. S. Diller and H. B. Patton. 1902. 167 pp., 19 pls.

PP 10. Reconnaissance from Fort Hamlin to Kotzebue Sound, Alaska, by way of Dall, Kanuti, Allen, and Kowak rivers, by W. C. Mendenhall. 1902.68 pp., 10 pls.

PP 11. Clays of the United States east of the Mississippi River, by Heinrich Ries. 1903.298 pp., 9 pls.

PP 12. Geology of the Globe copper district, Arizona, by F. L. Ransome. 1903. 168 pp., 27 pls.

PP 13. Drainage modifications in southeastern Ohio and adjacent.parts of West Virginia and Kentucky, by W. G. Tight. 1903.111 pp., 17 pls.

B 208. Descriptive geology of Nevada south of the fortieth parallel and adjacent portions of California, by J. E. Spurr, 1903. $2 \lessdot 9$ pp., 8 pls.

B 209. Geology of Ascutney Mountain, Vermont, by R. A. Daly. 1903.122 pp., 7 pls.

WS 78. Preliminary report on artesian basins in southwestern Idaho and southeastern Oregon, by I. C. Russell. 1903. 51 pp., 2 pls.

PP 15. Mineral resources of the Mount Wrangell district, Alaska, by W. C. Mendenhall and F. C. Schrader. 1903. 71 pp., 10 pls.

PP 17. Preliminary report on the geology and water resources of Nebraska west of the one hundred and third meridian, by N. H. Darton. $1903.69 \mathrm{pp} ., 43 \mathrm{pls}$.

B 217. Notes on the geology of southwestern Idaho and southeastern Oregon, by I. C. Russell. 1903. 83 pp., 18 pls.

B 219. The ore deposits of Tonopah, Nevada (preliminary report), by J. E. Spurr. $1903 . \quad 31$ pp., 1 pl.

PP 20. A reconnaissance in northern Alaska in 1901, by F. C. Schrader. 1904.139 pp., 16 pls.

PP 21. The geology and ore deposits of the Bisbee quadrangle, Arizona, by F. L. Ransome. 1904.168 pp., 29 pls.

WS 90. Geology and water resources of part of the lower James River Valley, South Dakota, by J. E. Todd and C. M. Hall. 1904. 47 pp., 23 pls.

PP 25. The copper deposits of the Encampment district, Wyoming, by A. C. Spencer. 1904.107 pp., 2 pls.

PP 26. Economic resources of the northern Black Hills, by J. D. Irving, with contributions by S. F. Emmons and T. A. Jaggar, jr. 1904. 222, pp., 20 pls.

PP 27. A geological reconnaissance across the Bitterroot Range and Clearwater Mouncans in Montana and Idaho, by Waldemar Lindgren. $1904.12 \% \mathrm{pp} ., 15 \mathrm{pls}$. 
PP 31. Preliminary report on the geology of the Arbuckle and Wichita mountains in Indian Territory and Oklahoma, by J. A. Taff, with an appendix on reported ore deposits in the Wichita Mountains, by H. F. Bain. 1904.97 pp., 8 pls.

B 235. A geological reconnaissance across the Cascade Range near the forty-ninth parallel, by G. $O$. Smith and F. C. Calkins. 1904.103 pp., 4 pls.

B 236. The Porcupine placer district, Alaska, by C. W. Wright. 1904.35 pp., 10 pls.

B 237. Igneous rocks of the Highwood Mountains, Montana, by L. V. Pirsson. 1904. 208 pp., 7 pls.

B 238. Economic geology of the Iola quadrangle, Kansas, by G. I. Adams, Erasmuth Haworth, and W. R. Crane. 1901.83 pp., 1 pl.

PP 32. Geology and underground water resources of the central Great Plains, by N. H. Darton. 1905. 433 pp., 72 pls.

WS 110. Contributions to hydrology of eastern United States, 1904; M. L. Fuller, geologist in charge. 1905. 211 pp., 5 pls.

B 242. Geology of the Hudson Valley between the Hoosic and the Kinderhook, by T. Nelson Dale. 1904. 63 pp., 3 pls.

PP 34. The Delavan lobe of the Lake Michigan glacier of the Wisconsin stage of glaciation and associated phenomena, by W. C. Alden. 1904. $106 \mathrm{pp}$., $15 \mathrm{pls}$.

PP 35. Geology of the Perry Basin in southeastern Maine, by G. O. Smith and David White. 1905. 107 pp., 6 pls.

B 243. Cement materials and industry of the United States, by E. C. Eckel. 1905.395 pp., 15 pls.

B 246. Zinc and lead deposits of northeastern Illinois, by H. F. Bain. 1904.56 pp., 5 pls.

B 247. The Fairhaven gold placers of Seward Peninsula, Alaska, by F. H. Moffit. 1905.85 pp., 14 pls.

B 249; Limestones of southwestern Pennsylvania, by F. G. Clapp. 1905 . 52 pp., 7 pls.

$B$ 250. The petroleum fields of the Pacific coast of Alaska, with an account of the Bering River coal deposit, by G. C. Martin. 1905. 65 pp., 7 pls.

B 251. The gold placers of the Fortymile, Birch Creek, and Fairbanks regions, Alaska, by L. M. Prindle. 1905. $16 \mathrm{pp} ., 16 \mathrm{pls}$.

WS 118. Geology and water resources of a portion of east-central Washington, by F. C. Calkins. 1905. 96 pp., 4 pls.

B 252. Preliminary report on the geology and water resources of central Oregon, by I. C. Russell. 1905. 138 pp., 24 pls.

PP 36. The lead, zinc, and fluorspar deposits of western Kentucky, by E. O. Ulrich and W. S. Tangier Smith. 1905. 218 pp., 15 pls.

PP 38. Economic geology of the Bingham mining district of Utah, by J. M. Bontwell, with a chapter on areal geology, by Arthur Keith, and an introduction on general geology, by S. F. Emmons. 1905. 413 pp., 49 pls.

PP 41. The geology of the central Copper River region, Alaska, by W. C. Mendenhall. 1905. 133 pp., 20 pls.

B 254. Report of progress in the geological resturvey of the Cripple Creek district, Colorado, by Waldemar Lindgren and F. L. Ransome. 1904. $36 \mathrm{pp.}$

B 255. The fluorspar deposits of southern Illinois, by H. Foster Bain. 1905. 75 pp., 6 pls.

B 256. Mineral resources of the Elders Ridge quadrangle, Pennsylvania, by R. W. Stone. 1905. 85 pp., 12 pls.

? 257. Geology and Paleontology of the Judith River beds, by T. W. Stanton and J. B. Hatchey with a chapter on the fossil plants, by F. H. Knowlton. 1905.174 pp.,19 pls.

42. Geology of the Tonopah mining district, Nevada, by J. E. Spurr. 1905. 295 pp., 24 pls.

8 123. Geology and underground water conditions of the Jornada del Muerto, New Mexico, by C. R. Keyes. 1905. 42 pp., 9 pls.

NS 136. Underground waters of Salt River'Valley, Arizona, by W. T. Lee. $1905.194 \mathrm{pp} ., 24 \mathrm{pls.}$

PP 43. The copper deposits of Clifton-Morenci, Arizona, by Waldemar Lindgren. 1905.375 pp., 25 pls.

B 265. Geology of the Boulder district, Colorado, by N. M. Fenneman. 1905.101 pp., 5 pls.

B 267. The copper deposits of Missouri, by H. F. Bain and E. O. Ulrich. 1905. 52 pp., 1 pl.

PP 44. Underground water resources of Long Island, New York, by A. C. Veatch, and others. 1905. $394 \mathrm{pp} ., 34 \mathrm{pls}$.

WS 148. Geology and water resources of Oklahoma, by C. N. Gould. 1905.178 pp., 22 pls.

B 270. The configuration of the rock fioor of Greater New York, by W. H. Hobbs. 1905.96 pp., 5 pls.

B 272. Taconic physiography, by T. M. Dale. 1905 . 52 pp., 14 pls.

PP 45. The geography and geology of Alaska, a summary of existing knowledge, by A. H. Brooks, with a section on climate, by Cleveland Abbe, jr., and a topographic map and description thereof, by R. M. Goode. 1905.327 pp., 34 pls.

B 273. The drumlins of southeastern Wisconsin (preliminary paper), by W. C. Alden. 1905. 46 pp., 9 pls.

PP 46. Geology and underground water resources of northern Louisiana and southern Arkansas, by A. C. Veatch. $1906 . \quad-$ pp., 51 pls.

PP 49. Geology and mineral resources of part of the Cumberland Gap coal field, Kentucky, by G. H. Ashley and L. C. Glenn, in cooperation with the State Geological Department of Kentucky, C. J. Norwood, curator. 1906. 239 pp., 40 pls. 
PP 50. The Montana lobe of the Keewatin ice sheet, by F. H. H. Calhoun. 1906.62 pp., 7 pls. B 277. Mineral resources of Kenai Peninsula, Alaska: Gold fields of the Turnagain Arm region, 1 F. H. Moffit; and the coal fields of the Kachemak Bay region, by R. W. Stone. $1906.80 \mathrm{pp}$., $18 \mathrm{pls.}$

WS 154. The geology and water resources of the eastern portion of the Panhandle of Texas, by C. : Gould. 1906.64 pp., 15 pls.

B 278. Geology and coal resources of the Cape Lisburne region, Alaska, by A. J. Collier. 190 pp., 9 pls.

B 279. Mineral resources of the Kittanning and Rural Valley quadrangles, Pennsylvania, by Cr Butts. 1906. - pp., 11 pls.

B 280. The Rampart gold placer region, Alaska, by L. M. Prindle and F. L. Hess. 1906. 54 pp., '

B 282. Oil fields of the Texas-Louisiana Gulf Coastal Plain, by N. M. Fenneman. 1906. 146 pp..?

WS 1.57. Underground water in the valleys of Utah Lake and Jordan River, Utah, by G. B. R son. 1906. $\delta 1 \mathrm{pp} ., 9 \mathrm{pls}$.

PP 51. Geology of the Bighorn Mountains, by N. H. Darton. 1906.129 pp., 47 pls.

WS 158. Preliminary report on the geology and underground waters of the Roswell artesian New Mexico, by C. A. Fisher. 1906. 29 pp., 9 pls.

PP 52. Geology and underground waters of the Arkansas Valley in eastern Colorado, by N. H. 1 1906. 90 pp., 28 pls.

WS 159. Summary of underground-water resources of Mississippi, by A. F. Crider and L. C. v 1906. 86 pp., 6 pls.

PP 53. Geology and water resources of the Bighorn basin, Wyoming, by Cassius A. Fisher. 1906. 72 pp., 16 pls.

B 283. Geology and mineral resources of Mississippi, by A. F. Crider. 1906.99 pp., 4 pls.

B 286. Economic geology of the Beaver quadrangle, Pennsylvania (southern Beaverand northw: am Allegheny counties), by L. H. Woolsey. 1906 . - pp., 8 pls.

B 287. The Juneau gold belt, Alaska, by A. C. Spencer, and a reconnaissance of Admiralty 15 . Alaska, by C. W. Wright. 1906. 161 pp., 37 pls.

PP 54. The geology and gold deposits of the Cripple Creek district, Colorado, by W. Lindgren and F. L. Ransome: 1906 . - pp., 29 pls.

PP 55. Ore deposits of the Silver Peak quadrangle, Nevada, by J. E. Spurr. 1906.174 pp., 24 I

B 289. A reconnaissance of the Matanuska coal field, Alaska, in 1905, by G. C. Martin. 1906. : 5 pls.

WS 164. Underground waters of Tennessee and Kentucky west of Tennessee River and of an adja area in Illinois, by L. C. Glenn. $1906 .-$ pp., 7 pls.

B 293. A reconnaissance of some gold and tin deposits of the southern Appalachians, by L. C. Gr with notes on the Dahlonega mines, by w. Lindgren. 1906. 134 pp., 9 pls.

B 294. Zinc and lead deposits of the upper Mississippi Valley, by H. Foster Bain. 1906. - pp., $16 \mathrm{I}^{\text {" }}$

B 295. The Yukon-Tanana region, Alaska, description of Circle quadrangle, by L. M. Prindle. 19: 27 pp., 1 pl.

B 296. Economic geology of the Independence quadrangle, Kansas, by Frank C. Schrader , Erasmus Haworth. 1906. - pp., - pls.

WS 181. Geology and water resources of Owens Valley, California, by Willis T. Lee. 1906. $2 \%$ 6 pls.

B 297. The Yampa coal field, Routt County, Colo., by N. M. Fenneman, Hoyt S. Gale, and M. R. Campbell. 1906. 96 pp., 9 pls.

Correspondence should be addressed to

The Director,

September, 1906.

United States Ggological Survey, Washington, D. C. 




\section{Lithomount}

I $19,3: 297$ 


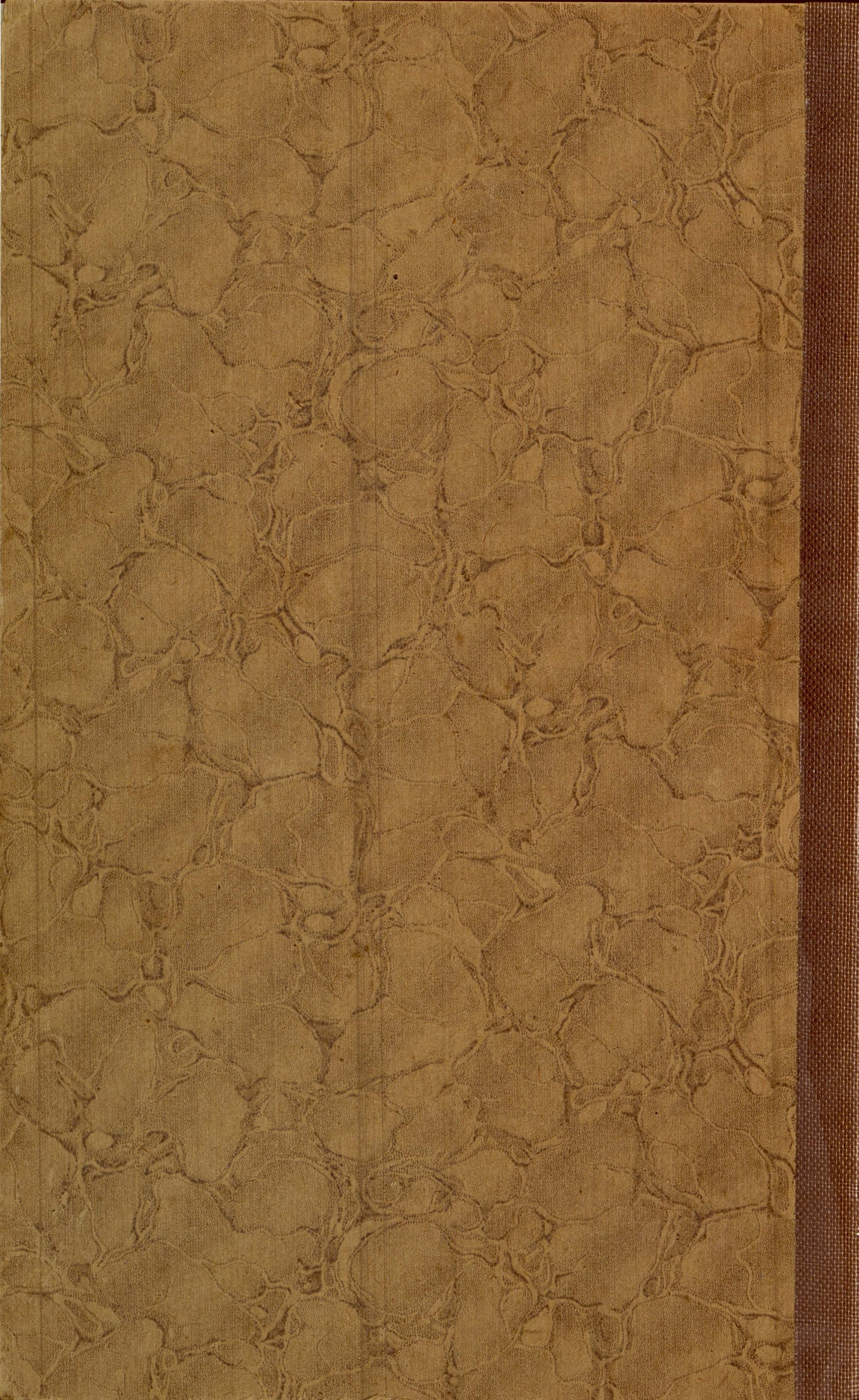

